\section{IARC FELLOWSHIPS FOR CANCER RESEARCH}

150 cours Albert-Thomas, 69372 Lyon Cedex 08, France

$$
\text { Tel: (33) (0)472 } 738448
$$

Fax: (33) (0)472 738080

Email: fel@iarc.fr

Contact: Fellowship Programme, International Agency for Res

\section{Postdoctoral Fellowships for Training in Cancer \\ Research}

Subjects: Epidemiology (all disciplines included), biostatistics, bioinformatics, and areas related to mechanisms of carcinogenesis including molecular and cell biology, molecular genetics, epigenetics and molecular pathology.

Eligibility: Applications from candidates from low- and middle-income countries or applicants from any part of the world, but with projects related to low- and middle-income countries, are encouraged.

Level of Study: Research

Type: Fellowship

Value: The annual stipend with dependent allowance is competitive compared with other international fellowship schemes. The cost of travel for the Fellow, and in certain circumstances for dependants, will be met, and health insurance covered

Length of Study: 2 years

Country of Study: France

Closing Date: September

Additional Information: For more details, please visit www.iarc.fr.

\section{IBM CORPORATION}

1 New Orchard Road, Armonk, New York, NY, 10504 1722, United States of America

Tel: (1) 8774266006

Fax: (1) 8667229226

Email: ews@us.ibm.com

Website: www.ibm.com

IBM stands today at the forefront of a worldwide industry that is revolutionizing the way in which enterprises, organizations and people operate and thrive. IBM strives to lead in the invention, development and manufacture of the industry's most advanced information technologies, including computer systems, software, storage systems, and microelectronics.

\section{IBM Herman Goldstine Postdoctoral Fellowship}

Subjects: Mathematics and computer science.

Purpose: To provide scientists of outstanding ability an opportunity to advance their scholarship as resident department members at the Research Center.

Eligibility: Open to candidates who have obtained a PhD or expect to receive a $\mathrm{PhD}$ before the fellowship commences in the second half of current year.

Level of Study: Research

Type: Fellowship

Value: Stipend is expected to be between $\$ 95,000$ and $\$ 120,000$, depending on the length of experience. An additional allowance for moving expenses will be provided

Length of Study: 1 year

Frequency: Annual

Country of Study: United States of America

No. of awards offered: Up to 2

Application Procedure: Applicants can download the application form from the website. The completed application form, curriculum vitae and abstract of PhD dissertation must be sent.

Closing Date: January 15th

Additional Information: Applications shall be accepted through email at goldpost@watson.ibm.com.

\section{IBM PhD Fellowship Program}

\section{Subjects: All subjects.}

Purpose: To honour exceptional $\mathrm{PhD}$ students in an array of focus areas of interest to IBM and fundamental to innovation.
Eligibility: Open to students nominated by a faculty member. They must be enroled full-time in a college or university $\mathrm{PhD}$ programme and they should have completed at least 1 year of study in their Doctoral programme at the time of their nomination.

Level of Study: Doctorate

Type: Fellowships

Value: US $\$ 17,500$

Length of Study: 3 years

Frequency: Annual

Application Procedure: All nominations for the IBM PhD Fellowship must be submitted by faculty electronically over the web on a standardized form. The nomination form will be available on the IBM PhD Fellowship nomination website from September 19th to October 31st. Closing Date: October 31st

Additional Information: Non-US citizens who wish to participate in an internship in the United States must obtain work authorization under the specifics of their particular visa. For further information, see website at www.research.ibm.com/university/phdfellowship/\#about OR contact phdfellow@us.ibm.com.

\section{ICFO - THE INSTITUTE OF PHOTONIC SCIENCES}

Mediterranean Technology Park, Av. Carl Friedrich Gauss, 3, Castelldefels, Barcelona, 08860, Spain

Tel: (34) 935534002

Fax: (34) 935534000

Email: secretariat@icfo.es

Website: www.icfo.eu

ICFO is a young research institution that aims to advance the very limits of knowledge in Photonics, namely the science and technology of harnessing Light. Light, especially laser light, is one of the major enabling technologies currently available to humankind. Our research programs target the global forefront of photonics, and aim to tackle important challenges faced by society at large. We focus on current and future problems in Health, Energy, Information, Safety, Security and caring for the Environment.

\section{Postdoctoral Research Position in Attosecond Electron Dynamics and Molecular Imaging in Spain}

Subjects: Attosecond Electron Dynamics and Molecular Imaging.

Purpose: For pursuing postdoctoral research at ICFO - The Institute of Photonic Sciences.

Eligibility: Candidates with an experimental background ideally related to atomic physics, attoscience, or physical chemistry. Experience with electron or ion imaging techniques and femtosecond lasers are highly desired, but not required. Candidates must hold an internationally recognized $\mathrm{PhD}$-equivalent degree (or evidence of its completion in the nearest future). No restrictions of citizenship or gender apply to the ICFO postdoctoral contracts.

Level of Study: Postdoctorate

Type: Scholarship

Country of Study: Spain

Application Procedure: The mode of applying is online.

Closing Date: October 31st

Additional Information: Initially, the contract is offered for a period of 1 year.

\section{ICMA CENTRE}

Henley Business School, The University of Reading, Whiteknights Park, PO Box 242, Reading, Berkshire, RG6 6BA, England

Tel: (44) 1183788239

Fax: (44) 1189314741

Email: admin@icmacentre.rdg.ac.uk

Website: www.icmacentre.ac.uk

Contact: Mrs Lucy Hogg, Marketing Manager

Part of Henley Business School, the ICMA Centre offers a range of undergraduate, postgraduate and executive education, research and consultancy for the financial markets. The practical application of finance theory is one of the Centre's key advantages and is achieved through the use of its three state-of-the-art dealing rooms. 


\section{ICMA Centre PhD Scholarship}

Subjects: Asset pricing, behavioural finance, commodity markets and derivatives, corporate finance and governance, credit risk and credit derivatives, equity and futures markets, financial engineering, financial regulation football finance, hedge funds, hedging strategies, high frequency econometrics, market microstructure, mergers and acquisitions, option pricing, pension schemes, portfolio management and performance assessment, quantitative finance, real estate finance and options, historical finance, liquidity risk, volatility and correlation modelling.

Purpose: To support research in the field.

Eligibility: Open to candidates with an excellent academic background who have completed, or who are in the process of completing, a Master's degree with grade averages at distinction level, in a course containing a significant proportion of finance.

Level of Study: Doctorate

Type: Scholarship

Value: Up to $£ 15,000$ paid quarterly plus $\mathrm{PhD}$ fee waiver

Length of Study: 1 year, renewable for another 2 years (subject to progress)

Frequency: Annual

Study Establishment: ICMA Centre, University of Reading

Country of Study: United Kingdom

No. of awards offered: Up to 20

Application Procedure: Applicants must complete an application

form, available from the Centre.

Closing Date: June 30th

Funding: Commercial, government, private

Contributor: ICMA Centre and the University of Reading

No. of awards given last year: 9

No. of applicants last year: 82

Additional Information: Please check website at www.icmacentre. ac.uk/study/phd-programme/phd-scholarships for more details.

\section{IEEE (INSTITUTE OF ELECTRICAL AND ELECTRONICS ENGINEERS, INC.) HISTORY CENTER}

at Stevens Institute of Technology, Samuel C. Williams Library, 3rd floor, Castle Point on Hudson, Hoboken, 3rd floor, 1 Castle point on Hudson, Hoboken, NJ, 07030, United States of America Tel: (1) 7325625450

Fax: (1) 7325626020

Email: ieee-history@ieee.org

Website: www.ieee.org/about/history_center/fellowship.html Contact: Mr Robert Colburn, Research Co-ordinator

The mission of the IEEE History Center is to preserve, research and promote the history of information and electrical technologies.

\section{IEEE Fellowship in the History of Electrical and Computing Technology}

Subjects: The history of electrical engineering and computer technology.

Purpose: To support graduate work in the history of electrical engineering.

Eligibility: Open to suitably qualified graduate students, or postdoctoral candidate studying the history of electrical or computing technologies.

Level of Study: Doctorate, Postdoctorate, Postgraduate

Type: Fellowship

Value: US $\$ 17,000$ plus US $\$ 3,000$ research budget

Length of Study: 1 year

Frequency: Annual

Study Establishment: A college or university of recognized standing Country of Study: Any country

No. of awards offered: 1

Application Procedure: Applicants must submit a completed application, transcripts, three letters of recommendation and a research proposal. Application materials can be downloaded from the website.

Closing Date: February 1st

Funding: Corporation

No. of awards given last year: 1
No. of applicants last year: 12

Additional Information: The fellowship is made possible by a grant from the IEEE Life Member Fund and is awarded by the IEEE History Committee. Application materials available on the website.

\section{IESE BUSINESS SCHOOL}

IESE Business School, Barcelona Campus, Avenida Pearson, 21, Barcelona, 08034, Spain

Tel: (34) 932534200

Fax: (34) 932534343

Email: info@iese.edu

Website: www.iese.edu

IESE Business School seeks to impact the management profession by offering high-quality learning to students and senior executives from around the world. Our programs are designed and delivered by faculty who are recognized for their dedication to teaching and research, with close ties with international business community.

\section{The Cámara de Comercio Scholarship}

Subjects: Business management.

Eligibility: Preference is given to students from developing countries.

Level of Study: MBA

Type: Scholarship

Value: All tuition fees

Length of Study: 1 year

Frequency: Annual

Study Establishment: IESE Business School

Country of Study: Spain

No. of awards offered: 2

Application Procedure: See website.

Closing Date: April 26th

Funding: Corporation

Contributor: Cámara de Comercio, Industria, Navegació de

Barcelona

\section{Ficosa International Scholarship}

Subjects: Business management.

Eligibility: Preference is given to students from Central or Eastern Europe.

Level of Study: MBA

Type: Scholarship

Value: All agreed costs

Length of Study: 1 year

Frequency: Annual

Study Establishment: IESE Business School

Country of Study: Spain

No. of awards offered: 1

Application Procedure: See website.

Closing Date: April 26th

Funding: Corporation

Contributor: Ficosa International

\section{Forté Fellowships}

Eligibility: Open to all female applicants. Candidates should exhibit exemplary leadership through academic, team, community and creative leadership. Candidates should demonstrate a commitment to women and represent diverse educational and work backgrounds, career goals, ethnicities and citizenship.

Type: Scholarship

Value: 1 year's tuition fees

Frequency: Annual

Application Procedure: Applicants must apply through IESE Scholarship Form (included in the MBA Application).

Closing Date: Please contact IESE

Additional Information: It is advised to all applicants to initiate the admissions process sufficiently in advance, in order to secure a place in the program.

\section{Fundación Ramón Areces Scholarship}

Subjects: Business management.

Eligibility: Open to applicants of Spanish nationality only.

Level of Study: MBA

Type: Scholarship 
Value: All tuition fees

Length of Study: 1 year

Frequency: Annual

Study Establishment: IESE Business School

Country of Study: Spain

Application Procedure: See website.

Closing Date: April 26th

Funding: Foundation

Contributor: Fudación Ramón Arces

\section{IESE AECI/Becas MAE}

Subjects: Business management.

Eligibility: Preference is given to candidates from nations designated as priority countries by the Director de la Cooperacion Espanola.

Level of Study: Professional development

Type: Scholarship

Value: All living expenses

Length of Study: 1 year

Frequency: Annual

Study Establishment: IESE Business School

Country of Study: Spain

No. of awards offered: Varies

Application Procedure: Check website for details.

Funding: Government

Contributor: The Spanish Ministry of Foreign Affairs

Additional Information: Details about the scholarship,

including application criteria and procedures, are available at www.becasmae.es.

\section{IESE Alumni Association Scholarships}

Subjects: Business management and MBA.

Purpose: To reward candidates who have demonstrated excellent work experience and personal merit.

Eligibility: For future MBA students who have demonstrated exceptional work experience and personal merit.

Level of Study: MBA

Type: Scholarship

Value: 50 per cent of tuition fees for the first and second year of the MBA program

Length of Study: 1 year

Frequency: Annual

Study Establishment: IESE Business School

Country of Study: Spain

No. of awards offered: 4

Application Procedure: Contact Admission's office.

Closing Date: June 28th

For further information contact:

MBA Admissions Department, Avda. Pearson 21, Barcelona, 08034, Spain

\section{IESE Donovan Data Systems Anniversary}

Subjects: Business management.

Purpose: To commemorate 30 years of DDS partnership with the advertising industry.

Eligibility: Preference is given to students interested in pursuing a career in advertising, marketing or communications.

Level of Study: Professional development

Type: Scholarship

Value: All agreed costs

Length of Study: 1 year

Frequency: Annual

Study Establishment: IESE Business School

No. of awards offered: 1

Application Procedure: See website.

Funding: Corporation

Contributor: Donovan Data Systems

Additional Information: The scholarship alternates each year between a European studying in North American and a North American Studying in Europe. Please check website www.donovanadata.com for details.

\section{IESE Private Foundation Scholarships}

Subjects: Business management and MBA.

Eligibility: Priority is given to students from developing countries.
Level of Study: MBA

Type: Scholarship

Value: All agreed costs

Length of Study: 1 year

Frequency: Annual

Study Establishment: IESE Business School

Country of Study: Spain

No. of awards offered: 4

Application Procedure: See website.

Closing Date: April 26th

Funding: Private

\section{IESE Trust Scholarships}

Subjects: Business management.

Eligibility: Outstanding academic records, excellent professional

experience and personal merit.

Level of Study: Professional development

Type: Scholarship

Value: Cover 25 or 50 per cent of tuition fees

Length of Study: 1 year

Frequency: Annual

Study Establishment: IESE Business School

Country of Study: Spain

No. of awards offered: $20-30$

Application Procedure: Contact Admissions Office.

Funding: Trusts

For further information contact:

MBA Admissions Department, Avda. Pearson, 21, Barcelona, 08034 Spain

\section{ONCE Foundation Scholarships}

Purpose: IESE and Fundación ONCE offer an annual scholarship for physically disabled individuals who would like to carry out the Executive MBA programme. These scholarships underscore IESE's aim of supporting the integration of those with physical disabilities in the business world, as well as high level education for this group within society.

Eligibility: In order to qualify for these scholarships, applicants must be recognized legally as being 33 per cent disabled. A copy of the candidate's official Certificate of Disability is required.

Type: Scholarship

Value: Up to $€ 37,290$, which is deducted from the total cost of the Executive MBA tuition

Closing Date: Please refer to the website

Additional Information: A committee that includes members of Fundación ONCE and IESE's EMBA program will select the scholarship recipient. Scholarship holders will be announced a few weeks after submitting all required documentation.

\section{ILLINOIS TEACHERS ESOL \& BILINGUAL EDUCATION (ITBE)}

PMB 2328926 N. Greenwood, Niles, IL, 60714-5163, United States of America

Tel: (1) 3124094770

Email: awards@itbe.org

Website: www.itbe.org

The ITBE is a non-profit organization of individuals involved in professional development legislation, government issues and specialist interest groups for the teaching of English to speakers of other languages and bilingual education.

\section{ITBE Graduate Scholarship}

Subjects: Bilingual education and teaching English to speakers of other languages.

Eligibility: a graduate student presently enroled full or part-time in an accredited college or university program in TESOL or bilingual education or a practicing ESL/bilingual education professional with concrete plans to enrol in relevant graduate coursework.

Level of Study: Postgraduate

Type: Scholarship

Value: US $\$ 1,000$ 
Length of Study: 1 year

Frequency: Annual

Application Procedure: Submit application form and follow further instructions on the website.

Closing Date: January 5th

For further information contact:

c/o Albany Park Community Center, 5101 N Kimball Ave, 2nd Floor, Chicago, IL, 60625

Contact: Britt Johnson, Illinois TESOL-BE Awards Chair

\section{INDIA HABITAT CENTRE}

Visual Arts Galley, Lodhi Road, New Delhi, 110-003, India Tel: (91) $1124682001 / 05$

Fax: (91) 1124682010

Email: info@indiahabitat.org

Website: www.indiahabitat.org

The India Habitat Centre was conceived to provide a physical environment that would serve as a catalyst for a synergetic relationship between individuals and institutions working in diverse habitat related areas and, therefore, maximize their total effectiveness.

\section{India Habitat Centre Fellowship for Photography}

Subjects: Photography.

Purpose: To promote photography as an art form.

Eligibility: Open to Indian nationals who are between 21 and 40 years of age and who do not hold any other fellowship.

Level of Study: Professional development

Type: Fellowship

Value: INR 120,000

Frequency: Annual

Country of Study: India

Application Procedure: Applicants must send a project summary, curriculum vitae and reference letters.

Closing Date: August 31st

Additional Information: Entries with less/more than the required

12 images will be eliminated.

For further information contact:

Visual Arts Gallery

Email: alkapande@indiahabitat.org

Contact: Dr Alka Pande

\section{INDIAN COUNCIL OF SOCIAL SCIENCE RESEARCH (ICSSR)}

35 Firozshah Road, New Delhi, 110-001, India

Tel: (91) 1126179849

Fax: (91) 1126179836

Email: info@icssr.org

Website: www.icssr.org

Contact: Deputy Director

The Indian Council of Social Science Research (ICSSR) is an autonomous organization, funded by the Indian Government to promote research in the social sciences. It provides grants in aid for research projects, fellowships and study grants for young people and gives publication grants. It established the National Social Science Documentation Centre and Archives for providing information to social scientists.

\section{Doctoral Fellowships}

Subjects: Social science.

Purpose: To provide opportunities for social scientists to engage themselves in full-time research on important themes of their choice or to write books about their research

Eligibility: Open to applicants who are not above 35 years of age, who hold a Master's degree in social sciences from a recognized university with a minimum overall aggregate of 55 per cent. Applicants must be registered for PhD in social sciences and cleared the MPhil, National Eligibility Test.

Level of Study: Doctorate
Type: Fellowships

Value: INR 16,000 per month (unemployed scholars) and salary protection (employed scholars). Contingency grant of INR 15,000 per year

Frequency: Annual

Country of Study: India

No. of awards offered: 55

Application Procedure: Application forms can be downloaded from www.icssr.org.

Closing Date: Please see website for details

Additional Information: Fellowship amount for contingency grant

(Research Expenses) for completing a particular part of the doctoral work (fieldwork, computer analysis, printing of questionnaires, cartographic work and purchase of books and journals, etc.) will be INR 50,000 consolidated. The applicant requires to submit a budget for the same.

\section{General Fellowships}

Subjects: Humanities and social science.

Purpose: To encourage promising and potential scholars in further research.

Eligibility: Open to candidates who are below the age of 50 years, who have shown significant promise and potential for research.

Level of Study: Postgraduate, Research

Type: Fellowship

Value: INR 6,000 per month (unemployed scholars) and salary protection (employed scholars). Contingency grant of INR 12,000 per year

Length of Study: 2 years

Frequency: Annual

Country of Study: India

Closing Date: June 15th

\section{National Fellowships}

Subjects: Social science.

Purpose: To enable eminent social scientists, who have made outstanding contributions to research in their respective fields, to further continue their academic work.

Eligibility: Open to social scientists of eminence, preferably below the age of 70 years.

Level of Study: Research

Type: Fellowships

Value: Retired and unemployed scholars will be paid a fellowship amount of INR 55,000 per month plus a contingency grant of INR 60,000 per year

Length of Study: 2 years

Frequency: Annual

Country of Study: India

No. of awards offered: 6

\section{Senior Fellowships}

Subjects: Social science and humanities.

Purpose: To encourage professional social scientists who have their $\mathrm{PhD}$ and quality publications in the form of books and papers in professional journals to their credit.

Eligibility: Open to scientists who are not above 65 years of age and who hold a PhD. Social workers, journalists and civil servants known for their academic interests with record of publications may be considered.

Level of Study: Postgraduate, Research

Type: Fellowship

Value: The amount of Fellowship is INR 40,000 per month (consolidated) for not employed \& superannuated scholars Length of Study: 2 years

Frequency: Annual

Country of Study: India

Closing Date: There is no last date for applying

Additional Information: Applications for the Fellowships can be sent once they are invited through advertisements in the Website of the ICSSR, Association of Universities Newsletter (AIU), Employment News, the Economic and Political Weekly, Mainstream, and some important daily newspapers. Completed applications can be sent to the ICSSR throughout the year. There is no last date for applying. 


\section{INDIAN EDUCATION DEPARTMENT}

Government of India, Ministry of Human Resource Department, Shastri Bhavan, New Delhi, 110001, India

Tel: (91) 1123383936

Fax: (91) 1123381355

Email: webmaster.edu@nic.in

Website: www.education.nic.in

The origin of the Indian Education Department, Government of India, dates back to pre-independence days when for the first time a separate Department was created in 1910 to look after education. However, soon after India achieved its independence, a full fledged ministry of Education was established.

\section{Agatha Harrison Memorial Fellowship (St Antony's College, Oxford)}

Subjects: Modern Indian studies in history, economics, and political science.

Eligibility: Open to the residents of India with 60 per cent marks at Master's Degree level, PhD Degree in the subject field or published works of equivalent merit and minimum 3 years teaching experience at graduate/postgraduate level. Age between 30 and 40 years.

Level of Study: Postgraduate

Type: Fellowship

Value: UK£18,580 + UK£5,956 allowance and economy class air passage (both ways) borne by the Government of India

Length of Study: 1 year

Application Procedure: Applicants must send typed application with attested copies of testimonials, programme of study, photograph and other documents on plain paper.

Closing Date: March 31st

Funding: Government

Contributor: The Government of India

\section{For further information contact:}

Es. 4 Section (Scholarships), Ministry of Human Resource Development, Department of Education, (ES 4) External Scholarships Division, A1/w3 Curzon Road Barracks, K G Marg, New Delhi, 110001 , India

Contact: Section Officer

\section{Belgium Scholarships}

Subjects: Agronomy, environmental science, and photonics. Eligibility: Open to the candidates up to the age of 35 who are graduates in agronomy/micro-electronics/chemical eng/technology/ metallurgy/vet. science/environmental studies with 60 per cent or above marks with 2 years experience in the field for postgraduate studies.

Level of Study: Graduate

Type: Scholarship

Value: A monthly grant of $€ 675$ during one academic year (10 months) Length of Study: 10 months

No. of awards offered: 3

Application Procedure: Applicants must send typed application with attested copies of testimonials, programme of study and other documents on plain paper by notified date.

Closing Date: March 19th

Additional Information: Extensive medical and third party liability insurance and Travelling expenses from India to Belgium and back to be borne either by the candidate or his/her employer/sponsor.

\section{For further information contact:}

ES. 5, Ministry of Human Resource Development, Department of Higher Education, A2/w4, Curzon Road Barracks, KG Marg, New Delhi, 110 001, India

Contact: Section officer

\section{China Scholarships}

Subjects: Chinese language \& literature, fine arts (painting \& sculpture), botany, environmental science, plant breeding \& genetics, political science, sericulture and agronomy.

Eligibility: Open to the Indian nationals below 40 years who have 2-3 year Cert/Dip in basic Chinese Language from a recognized Institution or University, have degree in fine arts with 60 per cent and 60 per cent for other subjects at postgraduate level with work research experience of 2 years.

Level of Study: Graduate

Type: Scholarship

Value: The Chinese Government pays a sum of Yuans 2,000 per month to all senior advanced students, Yuans 1,400 per month to ordinary graduate students and Yuans 1,100 per month to undergraduate students. In addition, Government of India is paying supplementary grant of Yuans 1,170 per month Government of China will also provide boarding, lodging, medical care and bear expenditure on tuition and other fees, etc.

Length of Study: 1-4 years

No. of awards offered: 25

Application Procedure: Applicants must send the application duly sponsored by the employers (if employed) furnishing particulars (as per notified format) by the prescribed date.

Closing Date: March 20th

Contributor: Government of China in association with the government of India

\section{For further information contact:}

ES. 3 Section, Ministry of Human Resource Development, Department of Higher Education, External Scholarship Division, A1/w3, Curzon Road Barracks, KG Marg, New Delhi, 110 001, India Contact: Section Officer

\section{Commonwealth Scholarship/Fellowships in UK}

Subjects: All subjects.

Eligibility: Open to the Indian national residing in India completing tertiary education in English medium and graduated first Master's Degree as per requirement within the last 10 years as on October of the in-take year. For more details, check website.

Level of Study: Doctorate, Postgraduate

Type: Fellowship/Scholarship

Value: A personal maintenance allowance at the rate of $£ 977$ per month (£1,208 per month for those studying at institutions in the London Metropolitan area). A grant towards the expenses of preparing thesis or dissertation, where applicable. For Scholars selected by the Commission for awards exceeding 18 months, a spouse allowance of $£ 220$ per month is payable provided that the Scholar and spouse are residing together at the same address in the United Kingdom Length of Study: 1 year for postgraduation, 6 months for clinical training and 3 years for $\mathrm{PhD}$

Application Procedure: check the website for further details.

Closing Date: October 10th

Additional Information: Candidate should give one page academic justification for pursuing Master Degree course in UK.

\section{For further information contact:}

ES. 1 Section (Scholarships), Ministry of Human Resource Development, Department of Higher Education (ES 1), External Scholarships Division, A1/W3 Curzon Road Barracks, K G Marg, New Delhi,

110001 , India

Contact: Section Officer

\section{Czech Scholarships}

Subjects: Agriculture (for PhD), electrical/electronics engineering/ mechanical engineering (for Master's and PhD).

Eligibility: Uniformly good academic record with at least 60 per cent marks in relevant subject at Bachelor's degree for Masters study and 60 per cent or more at Master's level in science/engineering/ technology in the related subjects or equivalent qualification in the subject selected or in the allied field.

Level of Study: Postgraduate, Doctorate

Type: Scholarship

Value: 7,000 CZK for Master's and 7,500 CZK for Doctor's per month Length of Study: As per rules of Czech Universities

No. of awards offered: 4 ( 2 for PhD and 2 for Master's)

Application Procedure: Application, duly sponsored by the employers (if employed), furnishing particulars (as per notified format) may be submitted on plain paper by the prescribed date.

Additional Information: A Summary of study proposal needs to be furnished. Applicants who have graduated from Czech Universities will be given preference over other candidates. 


\section{For further information contact:}

ES-3 Section, Ministry of Human Resource Development, Department of Higher Education, External Scholarship Division, A1/W3, Curzon Road Barracks, KG Marg, New Delhi, 110 001, India

Tel: (91) 11 23382458, 23386401

Contact: Section officer

\section{Erasmus Mundus Scholarship Programme}

Subjects: All subjects

Purpose: For the benefit of Indian students.

Eligibility: Open to Indian nationals who are graduates from recognized institutions or universities.

Level of Study: Graduate

Type: Scholarships

Value: Covers airfare and living expenses

Length of Study: 1-2 years duration depending on the subject areas of study

Application Procedure: Applicants must apply directly to the

universities/consortium of universities constituted under the Erasmus

Mundus Programme.

Closing Date: February 18th

Contributor: European Union (EU)

For further information contact:

Email: eac-info@cec.eu.int

\section{Germany Scholarships}

Subjects: Mechanical engineering, electronics and communication engineering, bio-pharmacology, metallurgy, environmental science, bio-technology, agriculture and forestry, veterinary sciences and animal husbandry, electrical engineering.

Eligibility: Open to the candidates with 60 per cent marks at Master's Degree in the subject/related field, sociology and economics candidates possessing adequate knowledge of German language with 2 years experience in teaching, research or practical training after obtaining the prescribed qualification.

Level of Study: Doctorate, Postgraduate

Type: Fellowship

Value: $€ 1,800$ per month and other allowances

Length of Study: 1 year

No. of awards offered: 7

Application Procedure: Applicants must send typed application, duly sponsored by employer, with research programme, attested copies of testimonials and other documents submitted on plain paper (as per notified format) by the prescribed date.

Additional Information: Period of fellowship is preceded by a compulsory 4 months German language course to be conducted at one of the branches of the Goethe Institute in Germany. Preference is given to candidates having contacts with German Professors or placement at the German Institute.

\section{For further information contact:}

ES. 1 Section, Ministry of Human Resource Development, Department of Education (ES-I), External Scholarship Division, Curzon Road Barracks, K.G. Marg, New Delhi, 110 001, India

Contact: Section Officer

\section{Greece Scholarships}

Subjects: Mathematics, political philosophy/political thought. Eligibility: Open to the candidates below 40 years who have Master's Degree with 60 per cent or more marks with 2 years teaching/ research/practical experience. Candidates should be pursuing studies in universities or research centres.

Level of Study: Postgraduate

Type: Scholarship

Value: $€ 150,000$. Check website for more details

Length of Study: 10 months

No. of awards offered: 1

Application Procedure: Applicants must send typed format along with photocopies of certificates through employer, if employed.

Closing Date: Please check website

Additional Information: Travelling expenses from India to Greece and back to be borne by the candidate or his/her sponsor/employee.
For further information contact:

ES. 5 Section, Ministry of Human Resource Development, Department of Education (ES-5), A1/W3, Curzon Road Barracks, K.G. Marg, New Delhi, 110 001, India

\section{Ireland Scholarships}

Subjects: Environmental resources management, community health remedial and special education and developmental studies.

Eligibility: Open to the candidates up to the age 30 having First Class Bachelor's Degree in related subjects along with good knowledge about Ireland, and have stayed for 2 years in India after return from abroad for study/training.

Level of Study: Postgraduate

Type: Fellowship

Value: Fellowships cover return travel from India, university fee, living allowance in addition to supplement for books, preparation of thesis, warm clothing, etc.

Length of Study: 1 year

No. of awards offered: 6

Application Procedure: Applicants must send the typed application with attested copies of testimonials, photograph, plans for employment, and other documents on plain paper in prescribed format by notified date.

\section{For further information contact:}

ES.1 Section, Ministry of Human Resource Development, Department of Education, A.1/W.3, Curzon Road Barracks, K.G. Marg, New Delhi, 110001, India

Contact: Section Officer

\section{Israel Scholarships}

Subjects: Economics, business management, mass communication, environment studies, Judaism, Hebrew language, history of the Jewish people, agriculture, chemistry, biology, nano-biology and Middle East Studies.

Eligibility: No age limit. Candidates who have 55 per cent or more marks for humanities, 60 per cent or more for agriculture.

Level of Study: Graduate

Type: Scholarship

Value: Paid by Israeli Government to cover stay, tuition fees, health insurance, etc.

Length of Study: 8 months

No. of awards offered: 6 (4 for 8 months research and 2 for P.D.)

Application Procedure: Application, duly sponsored by the employers (if employed) furnishing particulars (as per notified format) may be submitted on plain paper, by the prescribed date.

Funding: Government

Contributor: Israeli Government

Additional Information: Passage cost from India to Israel and back is payable by the candidate/employer. Candidates who are staying abroad will not be considered. Candidate who are already abroad for more than 6 months for study/research/training are eligible to apply only if they stayed in India for 2 consecutive years after their return from abroad.

\section{For further information contact:}

ES. 3 Section, Ministry of Human Resource Development, Department of Higher Education, External Scholarship Division, A.1/W.3, Curzon Road Barracks, K.G. Marg, New Delhi, 110 001, India Contact: Section Officer

\section{Italy Scholarships}

Subjects: Fashion technology, economics and management, cultural heritage and restoration, information and communication technology, environment, energy, biotechnology and microelectronics.

Eligibility: Open to the candidates of age not more than 35 years who have Graduate or equivalent degree with 60 per cent marks in the subject opted from a recognized university or a Master or equivalent degree with 60 per cent marks with specialization in the subject opted from a recognized University.

Level of Study: Postgraduate

Type: Scholarship

Value: $€ 700$ per month, which is reduced to 50 per cent for scholarship holders of categories B, C, D and E

Length of Study: 1 year

No. of awards offered: Check website for details 
Application Procedure: Application in prescribed format with attested copies of testimonials, photograph, programme of study/ research, fitness certificate, two letters of introduction from Indian academic authorities and other documents may be submitted or plain paper. Employed persons are required to send their applications through their employer.

Additional Information: Candidates who have received offer/invitation or secured admission in the above specified subjects in any University or Institution in Italy will be preferred. Such candidates should produce before the Selection Committee a document proving the offer/invitation/admission. Some courses in the above subject are taught in English and Knowledge of Italian Language is not considered a condition for admission. However, the decision of the Universities/ Institutions where such courses are held shall be final in this regard. No international/national passage is offered by the Government of Italy for any of these scholarships. No international travel cost to and fro Italy or local travel cost while in Italy for any Category of the above Scholarships will be paid either by the Government of Italy or by the Government of India. Therefore, an undertaking to the effect that the international travel cost to and fro Italy and local passage while in Italy (if any) will be borne by the candidates or his/her employers/sponsors should also be submitted along with application.

\section{For further information contact:}

ES. 5 Section, Ministry of Human Resource Development, Department of Higher Education, A.2/W.4, Curzon Road Barracks, K.G. Marg, New Delhi, 110 001, India

Contact: Section Officer

\section{Japan Scholarships}

Subjects: Information technology, optical fibre communication, quality and reliability engineering (as applied to various systems like electricity and power, railways, heavy industry, heavy electronics), electronics \& communication, robotics, laser technology, biotechnology, Japanese language and literature, fisheries, Japanese studies, earthquake engineering, environmental science, architecture, aerospace engineering, material science/engineering.

Eligibility: Japanese language: Open to the Indian nationals residing in India of age below 35 years. Candidates who have enroled in the postgraduate degree in Japanese language or completed undergraduate degree in Japanese language or completed Level 2 of JLPT conducted in Japan foundation and have completed at least 3 years of Japanese language study in a university. For more details, check website address. Japanese studies: Master's degree in the relevant field with minimum 60 per cent marks. Research studies (PhD): Masters degree in the relevant field with minimum 60 per cent marks. Candidate having practical research/teaching/work experience after obtaining the prescribed qualification as on May 30th would be preferred. Students who have Bachelor's degree in science or arts or engineering and have completed 15 or 16 years curriculum (i.e. $12+3$ or $12+4$ ) are also eligible for the Research Students Scholarship of the Japanese government provided that they have minimum 60 per cent marks. Level of Study: Graduate, Doctorate

Type: Scholarship

Value: Covers study allowance, fee, part payment of medical expenses, accommodation, etc. Return air ticket is provided by the Japanese Government

Length of Study: 18-24 months (may be extended)

\section{No. of awards offered: 30}

Application Procedure: Applicants must send typed application on plain paper as per format notified, along with attested photocopies of the testimonials, photograph, programme of study/research and other documents. Employed candidates are required to send applications through their employers with NOC.

Funding: Government

Contributor: Government of Japan

Additional Information: Return air ticket is provided by the Japanese Government.

\section{For further information contact:}

ES. 3 Section, Ministry of Human Resource Development, Department of Higher Education, External Scholarship Division, A.1/W.3, Curzon Road Barracks, K.G. Marg, New Delhi, 110 001, India

Tel: (91) 11 23382458, 23386401

Contact: Section Officer

\section{Mexican Government Scholarship}

Subjects: Spanish History, Literature, Linguistics, Economics, Demography, Asia \& Africa.

Eligibility: Open to Indian nationals residing India. Age below 45 years. Candidates should have a degree/PhD from University. Additional Requirements: Sufficient knowledge of geography, culture and heritage of Mexico; 2 years consecutive stay in India after return from abroad for study/training/specialization.

Level of Study: Doctorate, Postgraduate

Type: Scholarship

Value: Monthly maintenance allowance, Registration and college fee, medical insurance to be paid by Government of Mexico. Travel expenses from India to Mexico payable by the Govt. of Mexico Length of Study: 1-2 years

No. of awards offered: 6

Application Procedure: Typed application (in prescribed format as notified) with attested copies of testimonials may be submitted on plain paper. Employed persons are required to send their applications through their employers within due date as notified.

Closing Date: September 17th

Funding: Government

Contributor: Government of Mexico

\section{For further information contact:}

ES.5 Section, Department of Higher Education, A.2/W.4, Curzon Road Barracks, K.G. Marg, New Delhi, 110 001, India

Contact: The Section Officer

\section{Mongolia Scholarships}

Subjects: Mongolian language and Mongolian study.

Eligibility: Open to the Indian nationals residing within the country are below 45 years. They should have Bachelor's degree along with good knowledge of English, and have stayed in India for 2 years consecutively after return from abroad for study/training.

Level of Study: Postgraduate

Type: Scholarship

Value: Course fees, living allowance, and free accommodation in hostel for the duration of stay. Travel expenses from India to Mongolia and back are payable by the candidate or his/her employer/sponsor Length of Study: 1 semester

No. of awards offered: 2

Application Procedure: Applicants must send a typed application duly sponsored by employer, with attested copies of testimonials, photograph, programme of study/research and other documents on plain paper by the prescribed date.

Additional Information: Advance applications may be considered provisionally pending sponsorship by employer within 2 weeks.

\section{For further information contact:}

ES. 1 Section (Scholarships), Ministry of Human Resource Development, Department of Education (ES 1), External Scholarships Division, A1/W3, Curzon Road Barracks, K.G. Marg, New Delhi, 110001 , India

Contact: Section Officer

\section{N.C.P.E.D.P. Rajiv Gandhi Postgraduate Scholarship \\ Scheme 2005}

Subjects: Medicine, surgery, engineering, architecture, management, business administration, social work, applied psychology, clinical psychology, etc.

Purpose: To enable disabled students with limited means to receive education or professional training at postgraduate and doctoral levels. Eligibility: Open to Indian nationals between 18 and 35 years of age. The scholarship may be awarded to students with the disabilities as recognized by N.C.P.E.D.P. The candidate should be either pursuing or should have gained admission to a full-time course in an Indian university established by law or in a recognized equivalent institution. Level of Study: Doctorate, Postgraduate

Type: Scholarship

Value: INR 1,200 per month

Frequency: Annual

No. of awards offered: Varies

Application Procedure: Applicants must apply to the National Centre for Promotion of Employment for Disabled People.

Funding: Government 
Additional Information: A scholarship will be provided for the entire duration of the approved course. Scholarship money will be released every 3 months. N.C.P.E.D.P. reserves the right to change the scheme and/or amend the rules without any notice. The income of the candidate or his parents/guardians should not exceed INR 5,000 per month. At the discretion of the awarding authority, a scholarship may also be awarded for a professional course of Indira Gandhi National Open University (IGNOU) or any other recognized Open University.

\section{For further information contact:}

National Centre for Promotion of Employment for Disabled People, A-77, South Extension, Part II, New Delhi, 110049

Tel: + 9111262656 47/48

Email: education@ncpedp.org

Website: www.ncpedp.org

\section{Narotam Sekhsaria Foundation Scholarship (Tribal)}

Subjects: Engineering, technology, and sciences.

Purpose: For upliftment of SC candidates.

Eligibility: Open to candidates with a Bachelor's degree (minimum 50 per cent and 2 years of relevant work experience) and Master's degree (2 years of teaching/professional experience), or MPhil. For $\mathrm{PhD}$, minimum 5 years of teaching/professional experience is required. Age limit applicable is 35 years.

Level of Study: Doctorate, Graduate, Postgraduate

Type: Scholarship

Value: A fellowship of INR 26,000 per month

Length of Study: 2 years Masters degree, 3 years $\mathrm{PhD}$, and

1-6 months postdoctoral research

Country of Study: India

No. of awards offered: 10

Application Procedure: check the website for further details.

Funding: Government

Additional Information: Income limits is INR 18,000 per month for al categories.

\section{For further information contact:}

Information Facilitation Centre, Ministry of Environment and Forests, Paryavaran Bhawan, CGO Complex, Lodi Road, New Delhi, 110003 India

Website: www.envfor.nic.in

\section{Narotam Sekhsaria Foundation Scholarships}

Subjects: Pure sciences, applied sciences, social sciences and humanities, law, architecture, and management.

Purpose: To offer various scholarships for pursuing higher education in different streams.

Eligibility: Open to nationals residing in India. The upper age limit is 30 years. Should be a graduate of a recognized university (students in the final year of a degree course and those awaiting their results are also eligible to apply).

Level of Study: Postdoctorate

Type: Postgraduate scholarships

Value: Up to INR 200,000 , is awarded on the basis of the

Foundation's assessment of prospective candidates.

Country of Study: India

Application Procedure: The candidate is required to complete the registration online at http://pg.nsfoundation.co.in. Upon registration, the login credentials will be sent to the registered email ID Once the registration is complete, an application fee of INR 500 is payable either online through Net Banking or offline by sending a Demand Draft issued in favour of the Narotam Sekhsaria

Foundation.

Closing Date: March 20th

Funding: Foundation

Additional Information: For more information on the Scholarship Programme please contact: pgscholarship@nsfoundation.co.in.

\section{For further information contact:}

Narottam Sekhsaria Foundation, 46, Maker Chambers III, Nariman Point, Mumbai, Maharashtra, 400021, India

Website: http://pg.nsfoundation.co.in/Home/Scholarship

\section{National Doctoral Fellowships}

Subjects: Various fields of science and technology.

Eligibility: Open to candidates who are below 35 years as on August $31 \mathrm{st}$ of the year of application. A relaxation of 5 years for SC/ST,

physically handicapped, and women. The applicant should possess a First Class Master's Degree in areas of technical education such as ME, M Tech, M Pharm, M Arch, MBA, MS by research or equivalent or should have scored a minimum of 60 per cent aggregate marks in master's degree examination or equivalent if class is not declared

Level of Study: Doctorate, Postdoctorate

Type: Fellowship

Value: INR 12,000 per month, a contingency grant of INR 25,000 per year, and overhead charges of INR 20,000 per year to be paid to the host institution

Length of Study: 3 years plus an extension up to 1 year

Frequency: Annual

No. of awards offered: 50

Application Procedure: Short-listed candidates are called for interview in September/October. Final selection is made from merit list prepared on the basis of candidate's performance in interview.

Closing Date: August

Funding: Government

Contributor: All India Council For Technical Education (AICTE) Additional Information: Short-listed candidates will be called for interview sometime in September/October. The candidate should be in the first year of full-time doctoral programme in one of the host institutions listed in the Annexure.

\section{For further information contact:}

All India Council For Technical Education, Indira Gandhi Sports Complex, I.P. Estate, New Delhi, 110 002, India

Tel: (91) 11233925 06/63/64/65/68/71/73/74/78

Fax: (91) 112339255

Website: www.aicte.ernet.in

\section{New Zealand Scholarship}

Subjects: Education, primary health, sustainable rural livelihoods (including livestock, forestry, fisheries and horticulture).

Eligibility: Open to the Indian nationals residing in India who have completed their Master's degree with 60 per cent marks in opted subject field.

Level of Study: Doctorate

Type: Scholarship

Value: Travel expenses. Expenditure on board, lodging, books, study material, tuition fee, internal travel related to studies and medical care is met by donor country

Application Procedure: Applicants must send the application typed in English on plain paper as per format notified, with attested photocopies of the certificates, through their employer, if employed, within the date as notified along with the name of the scholarship scheme and the country, namely, United Kingdom or New Zealand to the below address.

Closing Date: June 15th

Additional Information: Applicants must have knowledge of India and of the donor country, and should have stayed for 2 consecutive years in India after return from abroad for study/training/specialization. Candidates qualifying from universities which do not award class/ division, requirements in lieu of First Class 60 per cent marks. For candidates who are doing PhD/MPhil after completion of Master's degree, actual period of research is taken into consideration as experience.

\section{For further information contact:}

ES.4 Section (Scholarships), Ministry of Human Resource Development, Department of Higher Education (ES 4), External Scholarships Division, A2/W4, Curzon Road Barracks, K.G. Marg, New Delhi, 110 001, India

Contact: Section Officer

\section{Norway Scholarships}

Subjects: All subjects.

Eligibility: Open to the Indian national residents. Please check website.

Level of Study: Predoctorate, Postgraduate

Type: Scholarship 
Value: Please see website for details Length of Study: Varies

No. of awards offered: Varies

Application Procedure: Typed application with attested copies of testimonials, programme of study, photograph and other documents should be submitted on plain paper (as per format notified) by prescribed date. Employed persons should send their applications duly sponsored. Late application may not be considered. Academic year starts from August every year.

Additional Information: Advanced applications may not considered. Enclose a letter of invitation from a host institution in Norway where the candidate wishes to study or carry out research. Enclose a description of the project/purpose of the planned study/research stay in Norway. Enclose a recent letter of invitation from (or on behalf of) a member of the scientific staff of a Norwegian host institution - valid for the planned study/research stay in Norway (www.studyinnorway.no) Enclose a recent letter of recommendation from home institution with relevance to the planned study/research stay in Norway. Have good working knowledge of English or Norwegian (Danish/Swedish) Focus the professional programme around one host institution.

\section{For further information contact:}

ES. 5 Section (Scholarships), Ministry of Human Resource Development, Department of Higher Education, A2/W4, Curzon Road

Barracks, K.G. Marg, New Delhi, 110 001, India

Contact: Section Officer

\section{Portugal Scholarships}

Subjects: Portuguese language and culture.

Eligibility: Open to the university teachers of age up to 45 who possess a Master's Degree in the concerned subject, know Portuguese language and be willing to undertake research in the Portuguese language and culture and have secured admissions or acceptance in a Portuguese Institute or university.

Level of Study: Postgraduate, Research

Type: Scholarship

Value: $€ 500$ (equivalent to INR 34,628 ) per month. $€ 450$ (equivalent INR 31,165 . First month grant will be $€ 825$ equivalent to INR 57,137 ) Length of Study: 8-12 months

No. of awards offered: 1 scholarship per month for postgraduate studies, 2 scholarships for research work for the period not exceeding 12 months and 6 scholarships of 8 months duration each for pursuing annual course of Portuguese language and culture

Application Procedure: Applicants must send typed application on plain paper as per format notified, along with attested photocopies of the testimonials, programme of study/research, medical fitness report, duly sponsored, if employed.

Funding: Government

Contributor: Government of Portugal

Additional Information: Advanced application may be considered if the 'NOC' from employer can be produced at the time of interview.

For further information contact:

ES.5 Section (Scholarships), Ministry of Human Resource Development, Department of Education (ES 5), External Scholarships Division, A1/W3, Curzon Road Barracks, K.G. Marg, New Delhi, 110001 , India

Contact: Section Officer

\section{Postgraduate Indira Gandhi Scholarship Scheme for Single Girl Child}

Subjects: All subjects.

Purpose: To achieve and promote girls education, UGC has introduced a Post Graduate Indira Gandhi Scholarship for Single Girl Child with an aim to compensate direct costs of girl education to all levels especially for such girls who happen to be the only girl child in their family.

Eligibility: Open to any female only-child who has taken admission in Master's degree programmes in any recognized university or a postgraduate college. Girl students up to the age of 30 years at the time of admission in PG courses are eligible.

Level of Study: Graduate, Postgraduate

Type: Scholarship

Value: INR 2,000 per month. No tuition fees will be charged

Length of Study: 2 years

Frequency: Annual
No. of awards offered: 1,200

Application Procedure: Check the website address for further details.

Closing Date: October 3rd

Funding: Government

Contributor: The University Grants Commission

Additional Information: A student leaving the studies mid-way will have to take prior approval from the University Grants Commission by submitting an application along with justification through the concerned university and will have to refund the whole amount and the concerned institution will be responsible for this.

\section{For further information contact:}

University Grants Commission (UGC), Selections and Awards Bureau, Delhi University South Campus, Benito Juarez Marg, New Delhi, 110021, India

\section{Shastri Indo-Canadian Fellowships}

Subjects: Faculty research/enrichment, doctoral research, pilot project awards, visiting lectureships for study in the areas of women \& development, Canadian studies, development \& environment, social \& economic reform, private sector development, social sciences/ humanities.

Eligibility: Open to Indian students/professors who are permanent citizens of India. Please check details on the website for different IndoCanadian fellowships.

Level of Study: Postgraduate

Type: Fellowship

Value: Fellowships cover return travel from India, University fee, living allowance in addition to supplement for books, preparation of thesis, warm clothing

Length of Study: 4 years (PhD) and 2 years (Masters)

Frequency: Annual

Application Procedure: Applicants must send typed application with attested copies of testimonials, photograph, plans for employment, and other documents on plain paper in prescribed format by notified date (employed persons are expected to send their applications through their employer). For details contact The Vice-President, Shastri Indo-Canadian Institute, 5 Bhai Vir Singh Marg, New Delhi110001.

Closing Date: Please refer to the website for details

\section{INDIAN INSTITUTE OF SCIENCE BANGALORE (IISC)}

The Registrar, Indian Institute of Science, Bangalore, 560012, India Tel: (91) 8023600757

Fax: (91) 802360 0683/0085

Email: regr@admin.iisc.ernet.in

Website: www.iisc.ernet.in

Contact: The Registrar

The Indian Institute of Science (IISc) was started in 1909 through the pioneering vision of $\mathrm{J} N$ Tata. Since then, it has grown into a premier institution of research and advanced instruction, with more than 2,000 active researchers working in almost all frontier areas of science and technology.

\section{IISc Kishore Vaigyanik Protsahan Yojana Fellowships}

Subjects: Science, engineering and medicine.

Purpose: To assist students in realizing their potential and to ensure that the best scientific talent is developed for research and growth in the country.

Eligibility: Open to Indian citizens.

Level of Study: Graduate, Postdoctorate, Postgraduate, Predoctorate, Research

Type: Fellowship

Value: INR 4,000-7,000 per month and contingency grants of INR $16,000-28,000$

Frequency: Annual

Study Establishment: Indian Institute of Science, Bangalore

Country of Study: India

Application Procedure: Applicants can download the application

form from the website.

Closing Date: September 


\section{For further information contact:}

Indian Institute of Science, Bangalore, Kishore Vaigyanik Protsahan Yojana, 560 012, India

Tel: (91) 802360 1008, 8022932976

Email: kvpy@admin.iisc.ernet.in

Website: www.kvpy.org.in/main/fellowship.htm

Contact: The Convener

\section{INDIAN INSTITUTE OF TECHNOLOGY (IIT)}

Department of Computer Science and Engineering, Kanpur, UP, 208016, India

Tel: (91) $5122597338 / 7638$

Fax: (91) 5122597586

Email: pgadm@cse.iitk.ac.in

Website: www.cse.iitk.ac.in

Contact: Harish Karnick, Professor and Head

Indian Institute of Technology (IIT) imparts training to students to make them competent, motivated engineers and scientists. The Institute not only celebrates freedom of thought, cultivates vision and encourages growth, but also inculcates human values and concern for the environment and the society.

\section{Infosys Fellowship for PhD Students}

Subjects: Computer science and engineering.

Purpose: To support those interested in pursuing the $\mathrm{PhD}$ programme in the Department of Computer Science and Engineering at IIT Kanpur.

Eligibility: Open to deserving students who have a MTech/ME in any branch of engineering and who have secured admission into the PhD programme.

Level of Study: Postgraduate

Type: Fellowship

Value: INR 225,000 and INR 250,000 per year. Out of this grant, INR 180,000 (INR 15,000 per month) will paid as stipend, remaining money can be utilized by the fellow for purchase of books, journals, payment of tuition fee, and travel for domestic and international conference attendance

Length of Study: $3.5-4$ years

Frequency: Annual

Study Establishment: IIT Kanpur

Country of Study: India

No. of awards offered: 2

Application Procedure: The applicant must submit a separate application form to the Department of Computer Science and Engineering.

Closing Date: Please check at www.cse.iitk.ac.in

For further information contact:

Kanpur, Uttar Pradesh, 208016, India

Email: pgadm@cse.iitk.ac.in

Contact: Admissions In-Charge (PhD) Computer science and engineering department, Indian Institute of Technology

\section{THE INDIANAPOLIS STAR}

307N Pennsylvania Street, PO Box 145, Indianapolis, IN, 46206-0145, United States of America

Tel: (1) 3174444000

Email: rpulliam@indystar.com

Website: www.indystar.com

The Indianapolis Star celebrated its 100th anniversary on June 6, 2003. The brainchild of Muncie industrialist George F. McCulloch, The Star challenged the two existing morning newspapers, the Journal and the Sentinel.

\section{Pulliam Journalism Fellowship}

Subjects: Reporting, news design and graphics and photojournalism. Purpose: To support newspaper journalism.

Eligibility: Open to candidates who have obtained graduate degrees. Level of Study: Professional development
Type: Fellowships

Value: US $\$ 5,500$

Length of Study: 10 weeks

Frequency: Annual

Country of Study: United States of America

No. of awards offered: 20

Application Procedure: Applicants can download the application form from the website. The completed application form along with samples of the best published writings, transcript of college credits, 3 letters of recommendation and a recent photograph must be sent. Closing Date: November 1st

Additional Information: Please call Russ Pulliam in Indianapolis at 3174446001 or Bill Hill in Phoenix at 6024444368 for any further information.

For further information contact:

Website: www2.indystar.com/pjf

Contact: Russell B Pulliam, Pulliam Fellowship Director

\section{INDICORPS}

3418 Highway 6 South, Suite B309, Houston, TX, 77082 , United States of America

Tel: (1) + $919377699950,+919833762666$

Email: info@indicorps.org

Website: www.indicorps.org

Indicorps is a non-partisan, non-religious, non-profit organization that encourages Indians around the world to actively participate in India's progress.

\section{Indicorps Fellowship}

Subjects: Social work with grassroots service organizations in India. Purpose: To implement projects that are in the organizations' and India's best interest.

Eligibility: Open to Indian citizens only.

Level of Study: Professional development

Type: Fellowship

Value: Varies

Length of Study: 1-2 years

Frequency: Annual

Country of Study: India

No. of awards offered: $10-15$

Application Procedure: Applicants must apply online.

Closing Date: March 1st

Additional Information: For further information about the application procedure mail to apply@indicorps.org.

For further information contact:

Indicorps, 3418 Highway 6 South Suite B \#309 Houston, Texas, United States of America

Tel: (1) 2816171057

\section{INSEAD}

Boulevard de Constance, F-77305 Fontainebleau Cedex, France

Tel: (33) 160724000

Fax: (33) 160745500

Email: mba.europe@insead.edu

Website: www.insead.edu/mba

Contact: Ms Irina Schneider-Maunoury, Senior Manager, MBA Financing

INSEAD is widely recognized as one of the most influential business schools in the world. With its second campus in Asia to complement its established presence in Europe, INSEAD is setting the pace in globalizing the MBA. The 1-year intensive MBA programme is focused on international general management.

\section{INSEAD Admiral Scholarship}

Purpose: To supports MBA participants at INSEAD who are selected either on the basis of merit at the time of admission, or, who have demonstrated financial need and submitted an application accordingly. 
Eligibility: All admitted candidates will be considered on the basis of merit as per the quality of their admission application. If a merit award is not allocated, then all candidates who qualify and have applied for need-based scholarships will be considered instead.

Type: Scholarship

Value: Up to $€ 15,000$

Frequency: Annual

No. of awards offered: 1 award per class

Additional Information: Please check website for more information.

\section{INSEAD Alcatel-Lucent scholarship}

Eligibility: Chinese candidates with the required profile (above) may apply. One or two candidates may also be invited for an interview (in person, by video or by telephone) with an Alcatel-Lucent representative in Asia in March (for the July Class) or September (for the December Class). Preference will be given to candidates who demonstrate financial need. If feasible, the INSEAD Alcatel-Lucent scholars will participate in a one-day event organized by AlcatelLucent for their scholars in France during the MBA Programme.

Type: Scholarship

Value: $€ 20,000$

No. of awards offered: 1 or 2 per class

Closing Date: February 11th for the July class and August 18th for the December class

Additional Information: Please check at http://mba.insead.edu for more information.

\section{INSEAD Alexis and Anne-Marie Habib Foundation scholarship}

Eligibility: Open to Lebanese nationals with strong academic credentials and demonstrated financial need.

Type: Scholarship

Value: Up to $€ 15,000$

No. of awards offered: 1 per class

Closing Date: February 11th the July class (starts September) and August 18th for the December class (starts January)

Additional Information: Please check at website for more details

\section{INSEAD Alumni Association (IAA) Scholarship Fund}

Eligibility: Candidates admitted to the MBA programme will be considered. Demonstrated financial need is a requirement.

Type: Scholarship

Value: Up to $€ 25,000$

Frequency: Annual

Closing Date: July class - November 9th (round 1), November 30th (round 2), February 29th (round 3); December class - April 20th

(round 1), June 16th (round 2), August 12th (round 3)

Additional Information: Please see the website for more details.

\section{INSEAD Alumni Fund (IAF) Diversity Scholarship(s)}

Subjects: MBA.

Purpose: To assist candidates admitted to the MBA programme.

Eligibility: Open to applicants from emerging or developing countries.

Level of Study: MBA

Type: Scholarship

Value: $£ 5,000-15,000$

Frequency: Annual

Study Establishment: INSEAD

No. of awards offered: Varies

Application Procedure: Applicants must complete a specific assignment, details of which are available from the website.

Closing Date: February 11th for July class and August 18th for December class

Contributor: Alumni

Additional Information: Please see the website for more details.

For further information contact:

Website: www.mba.insead.edu/scholarships

\section{INSEAD Alumni Fund (IAF) Robin Hood Scholarship}

Subjects: Candidates from emerging markets who have difficulty raising funds for the program.

Purpose: To assist MBA candidates from emerging and developing countries.
Eligibility: MBA.

Level of Study: MBA

Type: Scholarship

Value: $€ 10,000$

Frequency: Annual

Study Establishment: INSEAD

No. of awards offered: 2

Application Procedure: Apply online. Details are available on INSEAD'S website.

Closing Date: July class - November 10th (round 1), December 30th (round 2); December class - April 20th (round 1), June 16th (round 2)

Funding: Individuals

Contributor: Alumni

No. of awards given last year: 2

Additional Information: Country of study: France, Singapore.

INSEAD Alumni Fund (IAF) Special Profile Scholarship(s)

Purpose: For their class reunions, three classes - '68, '70, and '87J wish to empower exceptional individuals through the INSEAD experience. These awards of varying amounts will go to individuals who would not otherwise be able to attend INSEAD. By way of their backgrounds, work experience and personal profiles these candidates will bring an additional and unique diversity to INSEAD as well as to their own communities in the future as INSEAD alumni.

Eligibility: Only candidates who feel confident that they can fulfill the 'special' or 'different' category should apply. A strong preference will be given to those who demonstrate financial need.

Type: Scholarship

Value: $€ 10,000-25,000$

Frequency: Annual

Application Procedure: Complete the application on line and answer the appropriate essays questions.

Closing Date: February 13th each year for the July class (Rounds

1 and 2); August 22nd each year for the December class (Rounds 1 and 2)

Additional Information: Please check website for further information.

\section{INSEAD Alumni Fund (IAF) Women's Scholarship(s)}

Subjects: MBA.

Purpose: The IAF Women's Scholarships support INSEAD's commitment to bring outstanding women professionals to the MBA Programme and to increase representation of women in leadership positions in the business community.

Eligibility: INSEAD seeks bright, dynamic and motivated women who are making significant achievements in their professional and/or personal lives. Merit scholarships will be awarded to recognize these outstanding women. Their financial situation may also be taken into consideration.

Type: Scholarship

Value: $£ 5,000-15,000$

Frequency: Annual

No. of awards offered: $10-15$ awards per class

Application Procedure: To be considered for these scholarships please submit your application on line before the specified deadlines. Candidates will also be considered for the INSEAD Judith Connelly Delouvrier Scholarships.

Closing Date: February 13th each year for the July class (starts in September); August 22nd each year for the December class (starts in January)

Additional Information: Please check website for further information.

INSEAD Andrew Hordern Endowed Scholarship '91D

Subjects: To assist candidates who do not have traditional MBA backgrounds, e.g. artists, lawyers, scientists, not for profit etc.

Purpose: Non-traditional MBA backgrounds.

Eligibility: Open to MBA students.

Level of Study: MBA

Type: Scholarship

Value: $€ 10,000$

Frequency: Annual

Study Establishment: INSEAD

No. of awards offered: 1

Application Procedure: Applicants must apply online.

Closing Date: February 11 th for the July class (starts in September) and August 18th for the December class (starts in January) 
Funding: Individuals

Contributor: Alumni

Additional Information: Countries of study are France and Singapore.

\section{INSEAD Andy Burgess Endowed Scholarship for Social \\ Entrepreneurship}

Purpose: To provide one scholarship per year for a participant in each January class, in perpetuity, to deserving candidates admitted to the INSEAD MBA programme, who through their experience prior to INSEAD can demonstrate a commitment to social entrepreneurship. Eligibility: Candidates who demonstrate experience or commitment to social entrepreneurship. Entrepreneurial potential will be assessed, and preference will be given to candidates who demonstrate financial need.

Type: Scholarship

Value: Up to $€ 10,000$

Frequency: Annual

No. of awards offered: 1

Application Procedure: Complete the INSEAD online application. The successful candidate may expect to meet the donor during the program.

Closing Date: August 18th for December class (starts January) Additional Information: Please see the website for more details.

\section{INSEAD Belgian Alumni and Council Scholarship Fund} Subjects: MBA.

Purpose: To assist MBA participants.

Eligibility: Open to candidates of merit of Belgian nationality and those who have lived in Belgium for at least 5 years. Priority will be given to admitted applicants who intend to return to Belgium after their MBA

Level of Study: MBA

Type: Scholarship

Value: $€ 6,000$

Frequency: Annual

Study Establishment: INSEAD

No. of awards offered: 2

Application Procedure: Applicants must complete a specific assignment, details of which are available from the organization or from the website.

Closing Date: February 11th for the September class of the same year and August 18th for the January class of the following year Contributor: Alumni and the Belgian Council

\section{INSEAD Bischoff Family Endowed Scholarship}

Purpose: To support future participants from southern Africa and South-East Asia who demonstrate both merit and financial need. Eligibility: Candidates admitted to the INSEAD MBA Programme from these two regions who stand out in terms of previous academic achievement and who require financial assistance. Candidates from countries bordering South Africa (as well as Mauritius) and from South-East Asian countries (except for Korea and Japan) are eligible. Level of Study: Postgraduate

Type: Scholarship

Value: $€ 10,000$

Frequency: Annual

Application Procedure: To be considered for this scholarship,

please complete the Need-based Scholarship application.

Closing Date: February 13th each year for the July class (starts

August); August 22nd each year for the December class (starts January)

Additional Information: Please check website for further information.

\section{INSEAD Børsen/Danish Council Scholarship}

Subjects: MBA.

Purpose: To assist MBA participants.

Eligibility: Open to candidates of Danish nationality, admitted to the INSEAD MBA programme.

Level of Study: MBA

Type: Scholarship

Value: Up to $€ 15,000$

Frequency: Annual

Study Establishment: INSEAD

Country of Study: Other
No. of awards offered: 2

Application Procedure: Applicants must complete an application form, available from the website.

Closing Date: February 11th for the September class of the same year and August 18th for the January class of the following year Contributor: The Danish Council/Børsen

\section{INSEAD Canadian Foundation Scholarship}

Subjects: MBA.

Purpose: To provide financial assistance and scholarships to deserving Canadians admitted to the INSEAD MBA programme.

Eligibility: Open to candidates of Canadian nationality, preferably resident in Canada, who have been admitted to the INSEAD MBA programme and who intend to return to Canada.

Level of Study: MBA

Type: Scholarship

Value: Up to Canadian $\$ 10,000$

Frequency: Annual

Study Establishment: INSEAD

No. of awards offered: Varies

Application Procedure: Applicants must submit the following in support of their application: a covering letter requesting a scholarship specifying which campus the applicant is applying to, a budget detailing the need for financial assistance including current and expected sources of funding, a copy of a completed INSEAD admission form with essay and supporting documents, a copy of reference letters submitted in support of application to INSEAD, a copy of Graduate Management Admissions Test results, a copy of university transcripts and a copy of confirmation of admission to INSEAD.

Closing Date: May 31st for candidates admitted to the September intake of the same year and November 15th for candidates admitted to the January class of the following year

Funding: Foundation

Contributor: Alumni

Additional Information: The Canadian INSEAD Foundation is a nonprofit corporation whose purpose is to encourage Canadian students to develop an international business understanding and perspective.

For further information contact:

The Board of Trustees, Canadian INSEAD Foundation, c/o Richard Tarte, Société générale de financement du Québec, 600 de La Gauchetière Street, West Suite 1700, Montréal, QC, H3B 4L8, Canada

Tel: (1) 5148769290 ext. 2171

\section{INSEAD Citi Foundation Scholarship(s)}

Purpose: To foster an interest in the financial services industry. Eligibility: Candidates from Eastern Europe, the Middle East and Africa may apply. In addition, they will need to demonstrate their interest in the financial services industry, particularly within corporate and investment banking. Preference will be given to candidates who are able to demonstrate their need for financial assistance.

Type: Scholarship

Value: Approx. US $\$ 5,000$

Frequency: Annual

No. of awards offered: 2 or 3 per class

Closing Date: February 11 th for the July class (starts in September) and August 18th for the class December (starts in January)

INSEAD Deepak and Sunita Gupta Endowed Scholarship Subjects: For candidates from emerging markets who demonstrate proven financial need.

Purpose: For students from emerging markets.

Eligibility: Open to MBA students.

Level of Study: MBA

Type: Scholarship

Value: Up to $€ 25,000$

Length of Study: 1 year

Frequency: Annual

Study Establishment: INSEAD

No. of awards offered: 2

Application Procedure: Applicants must apply online through INSEAD'S website. 
Closing Date: February 11th for July class (starts in September) and August 18th for December class (starts in January)

Funding: Individuals

Contributor: Alumina

No. of awards given last year: 1

Additional Information: Countries of study are France and

Singapore.

\section{INSEAD EI Wakil-Lahham Scholarships}

Subjects: MBA.

Purpose: To help build human capacity and to create economic and social value in countries that make up the Southern Mediterranean Rim. They will be awarded to meritorious MBA participants at INSEAD who demonstrate limited financial means and who are citizens of countries from the Southern Mediterranean Rim, i.e. Morocco, Algeria, Tunisia, Libya, Egypt, Lebanon, Syria, (Jordan), and Turkey. Where applicable, first consideration will be given to Egyptian nationals and women participants from the countries within this geography.

Eligibility: Candidates from Morocco, Algeria, Tunisia, Libya, Egypt, Lebanon, Syria, (Jordan) and Turkey will be considered.

Type: Scholarship

Value: Up to $€ 25,000$

Frequency: Annual

Application Procedure: To be considered for this award, please apply under INSEAD Need-based Scholarships.

Closing Date: February 13th for July class (starts in September);

August 22nd for December class (starts in January)

Additional Information: Please check website for further information.

\section{INSEAD Eli Lilly and Company Innovation Scholarship}

Subjects: MBA.

Eligibility: Open to students of merit who demonstrate the capacity for innovative thinking and actions. Nationals from Africa, Asia, Central and Eastern Europe, Middle East, Central and South America, Turkey and Canada may apply.

Level of Study: MBA

Type: Scholarship

Value: Partial tuition

Frequency: Annual

Study Establishment: INSEAD

No. of awards offered: 2 per class

Application Procedure: Applicants must complete a specific assignment, details of which are available from the organization or from the website.

Closing Date: May 5th for the September intake of the same year and September 30th for the January intake of the following year

Contributor: Eli Lilly Foundation

Additional Information: Eli Lilly creates and delivers innovative pharmaceutical-based healthcare solutions that enable people worldwide to live longer, healthier and more active lives.

\section{INSEAD Elmar Schulte Diversity Scholarship}

Subjects: MBA.

Purpose: To encourage diversity in the INSEAD MBA programme.

Eligibility: Open to candidates from non-traditional MBA backgrounds who have been admitted to the programme.

Level of Study: MBA

Type: Scholarship

Value: Varies

Frequency: Annual

Study Establishment: INSEAD

Application Procedure: Applicants must complete an application form, available from the website.

Closing Date: May 5th for the September intake of the same year and September 30th for the January intake of the following year

Contributor: Alumni

\section{INSEAD Elof Hansson Scholarship Endowed Fund}

Subjects: MBA.

Purpose: To assist MBA participants.

Eligibility: Open to candidates of Swedish nationality who have been admitted to the INSEAD MBA programme.

Level of Study: MBA

Type: Scholarship

Value: $€ 6,000$
Frequency: Annual

Study Establishment: INSEAD

No. of awards offered: 2

Application Procedure: Applicants must complete an application form, available from the website.

Closing Date: February 11th for the September class of the same year and August 18th for the January class of the following year Funding: Foundation

Contributor: The Elof Hansson Foundation

\section{INSEAD Esa Hietala Endowed Scholarship}

Purpose: To assist Finnish candidates to fund the program.

Eligibility: Open to MBA students.

Level of Study: MBA

Type: Scholarship

Value: $€ 20,000$

Length of Study: 1 year

Frequency: Annual

Study Establishment: INSEAD

No. of awards offered: 1

Application Procedure: Applicants must apply online.

Closing Date: December class - April 20th (round 1), June 16th (round 2), August 12th (round 3); July class - November 9th, November 30th, February 29th

Funding: Individuals

Contributor: Alumni

No. of awards given last year: 1

Additional Information: Countries of study are France and

Singapore. Eligible to nationals of West European Countries and Finland.

\section{INSEAD Forte Foundation Fellowship}

Purpose: The Forte Foundation's mission is to substantially increase the number of women business owners and leaders by increasing the flow of women into key educational gateways and business networks.

Eligibility: Candidates for the Forte Fellowship should exhibit exemplary leadership in one or more ways: academic leadership; team leadership; community leadership; creative leadership. In addition INSEAD will look for measurable academic and personal achievement as well as involvement in issues related to the advancement of women. As Forte is currently a mainly U.S.-based network, it would be an advantage for a candidate to show how she can benefit from it.

Type: Fellowship

Value: $€ 15,000$

Frequency: Annual

No. of awards offered: 2

Closing Date: July class-November 9th (round 1), November 30th (round 2); December class-April 20th (round 1), June 16th (round 2) Additional Information: Please check website for more information.

\section{INSEAD Freddy Salem Scholarship(s)}

Purpose: Candidates for the INSEAD scholarships will need to demonstrate: (a) academic achievement and promise, (b) aptitude for business and financial management, and (c) a strong likelihood of spending the better part of their working careers in West Africa. In awarding these scholarships, INSEAD shall particularly seek candidates from Nigeria, Ghana, Togo and Benin.

Eligibility: Candidates must be nationals from a West Africa country (preferably Nigeria, Ghana, Togo and Benin) and will have spent most of their lives and received most or part of their education in Africa. Preference will be given to candidates who require proven financial assistance.

Type: Scholarship

Value: Up to $€ 20,000$

Frequency: Annual

Application Procedure: To be considered for this scholarship please refer to the INSEAD Need-based Scholarship pages and submit your application and background material accordingly.

Closing Date: July class-November 10th (round 1), December 30th (round 2), March 2nd (round 3); December class-May 12 (round 1), July 16th (round 2), September 22 (round 3)

Additional Information: Please check website for further information. 
INSEAD Giovanni Agnelli Endowed Scholarship

Subjects: MBA.

Purpose: To support MBA participants

Eligibility: Open to Italian candidates of high merit, admitted to the

INSEAD MBA programme.

Level of Study: MBA

Type: Scholarship

Value: Up to $€ 14,000$

Frequency: Annual

Study Establishment: INSEAD

No. of awards offered: $1-2$

Application Procedure: Applicants must complete an application form, available from the website.

Closing Date: February 11th for the September class of the same year and August 18th for the January class of the following year Contributor: Fiat group

Additional Information: This endowed scholarship is offered by the Fiat Group.

\section{INSEAD Goldman Sachs Scholarship for African \\ Nationals}

Purpose: The Goldman Sachs scholarships for African nationals at INSEAD is designed to give candidates from African countries access to a world-class MBA education. The scholarship winners will be allocated a Goldman Sachs mentor throughout the 10-month MBA programme.

Eligibility: The scholarship is open to all candidates from African countries studying at INSEAD on the Full-time MBA Programme. Successful candidates must demonstrate their desire to work in Africa and explain why building business in Africa is important to them.

Type: Scholarship

Value: Up to $€ 15,000$ per class

Frequency: Annual

Closing Date: February 13th for the July class (starts in September); August 22nd for the December class (starts in January)

Additional Information: Please check website for further information.

\section{INSEAD Greek Friends Scholarship}

Purpose: The Greek Friends of INSEAD Scholarship Fund was created in 2008 with donations from a number of INSEAD alumni and senior businessmen and women close to the school. They are interested in supporting and enhancing the Greek community at INSEAD and thereby the alumni network in Greece.

Eligibility: Greek nationals residing in Greece who have been admitted to the full-time MBA programme may apply. They must also demonstrate that they require financial assistance to complete year. Type: Scholarship

Value: Up to $€ 25,000$

Frequency: Annual

No. of awards offered: 1

Application Procedure: Candidates must complete the INSEAD Need-based Scholarship application to be considered for this award. Closing Date: February 13th for the July class (starts in September); August 22nd for the December class (starts in January)

Additional Information: Please check website for further information.

\section{INSEAD Greendale Foundation Scholarship}

Subjects: MBA.

Purpose: The Trustees of the Greendale Foundation wish to provide access to the INSEAD MBA programme to disadvantaged Southern and East Africans who are committed to developing international management expertise in Africa and who plan their careers in the Southern and East African regions.

Eligibility: Candidates must be nationals from Kenya, Malawi, Mozambique, South Africa (disadvantaged backgrounds), Tanzania, Uganda, Zambia or Zimbabwe (from disadvantaged backgrounds)who have undergone the major part of their education in Southern or East Africa. Preference will be given to those who have worked there prior to INSEAD. The candidate's financial situation will also be taken into consideration.

Type: Scholarship

Value: $€ 35,000$

Frequency: Annual

Application Procedure: Please check website for details.
Closing Date: February 13th each year for the July class (starts in September); August 22nd for the December class (starts in January) Additional Information: Scholarship recipients must return to work in these African regions within 3 years of graduation; in the event this condition is not met, the recipients will be asked by INSEAD to refund their scholarship within the fourth year after completion of the MBA Programme.

\section{INSEAD Groupe Galeries LaFayette Endowed Scholarship for Women}

Purpose: This Scholarship targets women participants at INSEAD who embrace the group's values of commitment to serving customers, regardless of their social background and ethnic origin.

Eligibility: Women candidates who have been admitted to the INSEAD MBA programme who identify with the goals and ambitions of Groupe Galeries Lafayette. Preference will be given to women from regions where the Group is or will be present, i.e. Western Europe, Middle East and Asia.

Type: Scholarship

Value: $€ 10,000$

Frequency: Annual

Closing Date: February 11th each year for the July class (starts in

September) and August 18th each year for the December class (starts in January)

Additional Information: Please check website for more information

\section{INSEAD Henry Grunfeld Foundation Scholarship}

Subjects: MBA.

Purpose: To aid MBA students who can demonstrate a commitment to a career in investment banking.

Eligibility: Open to participants from a U.K. background with an interest in pursuing a career in investment banking.

Level of Study: MBA

Type: Scholarship

Value: Up to $€ 12,500$

Frequency: Annual

Study Establishment: INSEAD

Country of Study: Other

No. of awards offered: 2 or 3

Application Procedure: Applicants must complete a specific assignment, details of which are available from the organization or from the website.

Closing Date: February 11 th for the September class of the same year and August 18th for the January class of the following year Contributor: The Henry Grunfeld Foundation

Additional Information: Henry Grunfeld was a co-founder of S G Warburg, the U.K. investment bank that became one of the largest securities firms in the world, combining merchant banking, securities broking and market-making

INSEAD lan Potter '93D \& Family Endowed Scholarship

Purpose: For candidates from East and South Asia.

Eligibility: Open to MBA students.

Level of Study: MBA

Type: Fellowships

Value: $€ 10,000$

Length of Study: 1 year

Frequency: Annual

Study Establishment: INSEAD

Application Procedure: Applicants must apply through INSEAD's website.

Closing Date: February 11 th each year for the July class (starts August) and August 18th each year for the December class (starts January)

Funding: Individuals

Contributor: Alumni

Additional Information: Countries of study are France and Singapore.

\section{INSEAD Jacques Nasser Endowed Leadership Scholarship}

Eligibility: Candidates who are citizens of an Arab country in the Middle East (including Egypt) or whose parents are/were citizens of one of these countries. Leadership potential will be assessed and a preference will be given to candidates who demonstrate financial need. 
Level of Study: MBA

Type: Scholarship

Value: Up to $€ 10,000$

Frequency: Annual

No. of awards offered: Up to 2

Closing Date: February 11th for the July class (starts in September) and August 18th for the December class (starts in January)

Additional Information: Please check website for more information.

\section{INSEAD Jewish Scholarship}

Subjects: MBA.

Purpose: An INSEAD alumnus offers scholarships to Jewish students admitted to the INSEAD MBA Programme; a limited number of small awards are made each year. In keeping with the spirit and tradition behind this award, the winners are encouraged to give back by making their own donation to scholarships at INSEAD through the Alumni Fund within a few years after graduation.

Eligibility: Jewish students who can justify difficulty in raising sufficient finances for their living expenses.

Type: Scholarship

Value: Up to $€ 5,000$

Frequency: Annual

Closing Date: February 13th each year for the July class (starts in September); August 22nd each year for the December class (starts in January)

Additional Information: Please check website for further information.

\section{INSEAD Judith Connelly Delouvrier Endowed \\ Scholarship}

Subjects: MBA.

Purpose: To support women undertaking the MBA.

Eligibility: Open to deserving American women admitted to the

September MBA programme.

Level of Study: MBA

Type: Scholarship

Value: Up to US $\$ 15,000$

Frequency: Annual

Study Establishment: INSEAD

No. of awards offered: 1

Application Procedure: Applicants must complete a specific assignment, details of which are available from the website.

Closing Date: February 11th for the September class of the same year and August 18th for January class of the same year Contributor: Alumni

Additional Information: This scholarship is offered in memory of Judith Connelly Delouvrier, wife of Phillippe Delouvrier, an INSEAD MBA of 1977, who was a victim of the TWA Flight 800 tragedy in 1996.

\section{INSEAD L'Oréal Scholarship}

Subjects: MBA.

Purpose: To foster creativity, diversity and entrepreneurial spirit within the MBA population.

Eligibility: Open to candidates of any nationality who demonstrate a capacity for creativity, innovation and entrepreneurial activity and who can demonstrate financial need.

Level of Study: MBA

Type: Scholarship

Value: Partial tuition fees

Length of Study: 1 year

Frequency: Annual

Study Establishment: INSEAD

No. of awards offered: 2 (per year) and 1 (per intake)

Closing Date: February 11th for the September class of the same year and August 18th for the January class of the following year Contributor: L'Oréal

\section{INSEAD Lister Vickery Memorial Scholarship}

Subjects: MBA.

Purpose: This scholarship, which is meant to assist MBA participants from Eastern Europe and Central Asian countries, was created in memory of Lister Vickery (MBA '66) by two of his INSEAD classmates and close friends. Over the years other classmates, former recipients of the award and members of Vickery family have all contributed to this scholarship.
Eligibility: Candidates from Eastern Europe or Central Asia who show potential for pursuing a career in industry in the region.

Preference will be given to a candidate who demonstrates financial need.

Type: Scholarship

Value: $€ 5,000$

Frequency: Annual

Application Procedure: To be considered for this scholarship. Please apply under INSEAD Need-based Scholarships.

Closing Date: February 13th for July class (starts in September), August 22nd for December class (starts in January)

Additional Information: Please check website for further information.

\section{INSEAD Louis Franck Scholarship}

Subjects: MBA.

Purpose: This scholarship is for young U.K. nationals who wish to further their education, develop an international outlook and equip themselves to attain the highest level of executive management. Eligibility: Open to candidates of U.K. nationality admitted to INSEAD. Financial need is neither a necessary nor a sufficient condition for being granted an award. Nevertheless, the candidate's financial position will be taken into account, and awards will not necessarily be granted to the best candidates if there is a sound candidate who is in financial need. Selected scholars are required to write a thesis or report, the subject of which is to be agreed upon with the trustees, and is to be presented to the trustees within 3 months of graduation.

Type: Scholarship

Value: Up to $€ 15,000$

Frequency: Annual

Study Establishment: INSEAD

No. of awards offered: Up to 8

Application Procedure: Applicants must complete a specific assignment, details of which are available from the website.

Closing Date: February 11th for the September class of the same year and August 18th for the January class of the following year Funding: Private

Contributor: The Louis Franck Trust

Additional Information: This scholarship was established in 1983 by Louis Franck, who served for many years on the Board of INSEAD.

\section{INSEAD Louis Vuitton Scholarship}

Purpose: The INSEAD Louis Vuitton scholarship is targeted at Chinese and Indian participants at INSEAD. By offering INSEAD participants a scholarship, Louis Vuitton Malletier aims to encourage the awareness of the challenges and opportunities for the luxury goods industry in the region.

Eligibility: To be eligible for the INSEAD Louis Vuitton Scholarship candidates must first be admitted to the INSEAD MBA programme. They must be a national of China or India, have lived or studied in one of these countries and ideally completed their first professional experience there as well. Preference will be given to candidates who require proven financial assistance. Experience in retail is a plus.

Type: Scholarship

Value: Up to $€ 25,000$

Frequency: Annual

Closing Date: February 13th for the July class (starts in August);

August 22nd for the December class (starts in January)

Additional Information: Please check website for further information.

\section{INSEAD Marguerre Endowed Scholarship(s) for Entrepreneurial Talent}

Purpose: The endowed fund will provide one or two scholarships per class to deserving candidates admitted to the INSEAD MBA programme who through their experience prior to INSEAD can demonstrate entrepreneurial talent.

Eligibility: Candidates with entrepreneurial talent and preference will be given to those who demonstrate financial need.

Type: Scholarship

Value: $€ 11,000$ if two awards or $€ 22,000$ if only one award per class Frequency: Annual

No. of awards offered: 1 or 2 per class

Closing Date: February 11th for July class (starts in September) and August 18 for December class (starts in January) 
INSEAD MBA '70 Special Profile Endowed Scholarship Subjects: MBA.

Purpose: The '70 class wishes to support well-qualified individuals from poor backgrounds who would not otherwise be able to attend INSEAD and thereby empower them through the INSEAD experience. Such special profiles can be candidates from socially, economically and/or politically challenged countries.

Eligibility: Candidates admitted to the MBA Programme with the above-mentioned profiles will be considered. Financial need will be taken into consideration.

Type: Scholarship

Value: Up to $€ 15,000$

Frequency: Annual

Application Procedure: To be considered for this award, candidates must complete the INSEAD Alumni Fund (IAF) Special Profiles Scholarship application.

Closing Date: February 13th for the July class (starts September); August 22nd for the December class (starts January)

Additional Information: Please check website for further information.

\section{INSEAD MBA '87J Special Profile Endowed Scholarship}

Subjects: MBA.

Purpose: The award will be made once a year to a candidate whose background, work experience and personal profile will bring an additional and unique diversity to INSEAD and in the future to their own communities as INSEAD alumni. Such special profiles can be candidates from socially, economically and/or politically challenged countries; a commitment to the not-for-profit sector; career in technological innovation that improves the environment. Candidates from emerging countries requiring financial assistance will also be considered.

Eligibility: Candidates admitted to the MBA Programme with the above mentioned profiles will be considered. Financial need will be taken into consideration.

Type: Scholarship

Value: Up to $€ 10,000$

Frequency: Annual

Application Procedure: To be considered for this award candidates must complete the INSEAD Alumni Fund (IAF) Special Profile

Scholarship application.

Closing Date: February 13th for the July class (starts September); August 22nd for the December class (starts January)

Additional Information: Please check website for further information.

\section{INSEAD MBA '89D Endowed Scholarship}

Subjects: MBA.

Purpose: The '89D class wishes to support well-qualified individuals who would not otherwise be able to attend INSEAD and thereby empower them through the INSEAD experience. Candidates requiring financial assistance will be considered.

Eligibility: Candidates admitted to the MBA Programme with the above mentioned profiles will be considered. Financial need will be taken into consideration.

Type: Scholarship

Value: Up to $€ 10,000$

Frequency: Annual

Application Procedure: To be considered for this scholarship, please complete the Need-based Scholarship application.

Closing Date: February 13th for the July class (starts September); August 22nd for the December class (starts January)

Additional Information: Please check website for further information.

\section{INSEAD Mette Roed Heyerdahl Memorial Scholarship}

Purpose: For women from Nepal, Uganda, Palestine, Turkey and Middle East.

Eligibility: Open to MBA students.

Level of Study: MBA

Type: Fellowships

Value: $€ 12,500$

Length of Study: 1 year

Frequency: Annual

Study Establishment: INSEAD

Application Procedure: Applicants must apply through INSEAD's website.
Closing Date: August 18th for December class (starts in January); February 11th for July class (starts in September)

Funding: Individuals

Contributor: Alumni

No. of awards given last year: 2

Additional Information: Countries of study are France and Singapore.

INSEAD Nelson Mandela Endowed Scholarship

Purpose: To assist African MBA candidates (sub-saharan Africa).

Eligibility: Open to MBA students.

Level of Study: MBA

Type: Scholarship

Value: $€ 20,000$

Length of Study: 1 year

Frequency: Annual

Study Establishment: INSEAD

No. of awards offered: 2

Application Procedure: Applicants must apply through INSEAD'S website.

Closing Date: February 11th for July class (starts in August) and

August 18th for December class (starts in January)

Funding: Individuals

Contributor: Alumni

No. of awards given last year: 2

Additional Information: Countries of study are France and Singapore.

\section{INSEAD Orange Endowed Scholarship(s) for Emerging \\ Markets}

Purpose: This endowed scholarship will support emerging market participants at INSEAD in perpetuity. Candidates need to be motivated to pursue their career in one of the regions where Orange operates. Experience or an interest in telecommunications is a plus. Eligibility: Candidates admitted to the MBA programme from Armenia, Brazil, Central African Republic, Dominican Republic, Egypt, India, Kenya, Madagascar, Moldova, Niger, Romania, Russia,

Slovakia, South Africa, United Arab Emirates (Dubai) and Uganda will be considered. Preference will also be given to candidates who demonstrate financial need. Knowledge of French would be a plus.

Type: Scholarship

Value: Up to $€ 20,000$

Frequency: Annual

Application Procedure: Applicants must submit their application online.

Closing Date: February 11th for July class (starts in September) and August 18th for December class (starts in January)

Additional Information: Please check website for more information.

\section{INSEAD Pereira Endowed Scholarship}

Purpose: For Portuguese applicants.

Eligibility: Open to MBA students.

Level of Study: MBA

Type: Scholarship

Value: $€ 10,000$

Length of Study: 1 year

Frequency: Annual

Study Establishment: INSEAD

No. of awards offered: 2

Application Procedure: Applicants must apply online through

INSEAD's website.

Closing Date: February 11th for July class (starts in September) and August 18th for december class (starts in January)

Funding: Individuals

Contributor: Alumni

No. of awards given last year: 2

Additional Information: Countries of study are France and Singapore. Eligible to nationals of West European countries and Portugal.

\section{INSEAD Russian Alumni Scholarship}

Subjects: MBA.

Purpose: This scholarship has been created by a group of Russian alumni in support of INSEAD's efforts to attract top talent from Russia to the MBA programme. They will be awarded to candidates whose educational and professional experience is merit worthy. The alumni wish that the candidates who benefit from their support will return and be successful in Russia. 
Eligibility: Russian nationals who have already been admitted to the MBA programme will be eligible. Candidates whose education and professional experience has a Russian focus and who demonstrate a strong potential for success in Russia will be considered. Preference will be given to candidates with proven financial need.

Type: Scholarship

Value: Up to $€ 10,000$

Frequency: Annual

Application Procedure: To be considered for this award please apply for the Need-based Scholarships.

Closing Date: February 13th for July class (starts in September); August 22nd for December class (starts in January)

Additional Information: Please check website for further information.

\section{INSEAD Russian Alumni Scholarship}

Subjects: MBA.

Purpose: This scholarship has been created by a group of Russian alumni in support of INSEAD's efforts to attract top talent from Russia to the MBA programme. They will be awarded to candidates whose educational and professional experience is merit worthy. The alumni wish that the candidates who benefit from their support will return and be successful in Russia.

Eligibility: Russian nationals who have already been admitted to the MBA programme will be eligible. Candidates whose education and professional experience has a Russian focus and who demonstrate a strong potential for success in Russia will be considered. Preference will be given to candidates with proven financial need.

Type: Scholarship

Value: Up to $€ 10,000$

Frequency: Annual

Application Procedure: To be considered for this award please apply for the Needbased Scholarships.

Closing Date: July class - November 10th (round 1), December 30th (round 2), March 2nd (round 3); December class - April 20th (round 1), June 16th (round 2), August 12th (round 3)

Additional Information: Please check website for further information.

\section{INSEAD Ryoichi Sasakawa Young Leaders Fellowship Fund (Sylff)}

Subjects: MBA.

Purpose: Sylff would like to encourage candidates of any nationality to broaden their knowledge and enhance their career opportunities through the INSEAD MBA programme. One award will be granted per class.

Eligibility: Candidates of any nationality who show strong leadership in a cross-cultural setting. Preference will be given to candidates who require financial assistance.

Type: Fellowship

Value: $€ 10,000$

Frequency: Annual

Closing Date: February 11th each year for the July class (starts in

September) and August 22nd each year for the December class

(starts in January)

Additional Information: Please check website for further information.

\section{INSEAD Ryoichi Sasakawa Young Leaders Fellowship Fund (Sylff)}

Subjects: Social sciences and humanities.

Eligibility: Candidates of any nationality who show strong leadership in a cross-cultural setting. Preference will be given to candidates who require financial assistance.

Level of Study: Graduate

Type: Fellowship

Value: $€ 10,000$

Frequency: Annual

No. of awards offered: 1 award per class

Closing Date: December class - May 12th (round 1), July 16th (round

2); December 2016 Class - April 20th (round 1), June 16th (round 2)

Contributor: Nippon Foundation

Additional Information: Please check website for more information.

\section{INSEAD Sam Akiwumi Endowed Scholarship - '07D}

Purpose: To assist candidates from Africa, preferably Ghanaians.

Eligibility: Open to MBA students. Preference will be given to

Ghanaians and to candidates who demonstrate financial need.

Level of Study: MBA
Type: Scholarship

Value: $€ 10,000$

Length of Study: 1 year

Frequency: Annual

Study Establishment: INSEAD

Application Procedure: Applicants must apply online through INSEAD's website.

Closing Date: February 11th for July class (starts in August) and August 18th for December class (starts in January)

Funding: Individuals

Contributor: Alumni

No. of awards given last year: 2

Additional Information: Countries of study are France and Singapore.

\section{INSEAD Sasakawa (SYLFF) Scholarships}

Subjects: MBA.

Purpose: To encourage candidates to broaden their knowledge and enhance their career leadership through the INSEAD MBA programme. Eligibility: Open to candidates of any nationality. The awards will be made on a competitive basis.

Level of Study: MBA

Type: Scholarship

Value: $€ 10,000$ depending on the number and quality of applications Frequency: Annual

Study Establishment: INSEAD

No. of awards offered: 1 or more per intake

Application Procedure: Applicants must complete a specific assignment, details of which are available from the website.

Closing Date: February 11th for the September class of the same year and August 18th for the January class of the following year Funding: Private

Contributor: The Sasakawa Young Leaders Fellowship Fund (SYLFF)

\section{INSEAD Sisley-Marc d'Ornano Scholarship}

\section{Subjects: MBA.}

Purpose: To support young graduates seeking further education in order to contribute to the economic development of Poland. Eligibility: Open to Polish nationals admitted to the INSEAD MBA programme who demonstrate a commitment to work in Poland for 3 years after the INSEAD MBA programme. The winner of the scholarship will agree to take up a professional activity in Poland for at least 3 years, and if not, the candidate is obliged to reimburse the scholarship.

Level of Study: MBA

Type: Scholarship

Value: $€ 25,000$

Frequency: Annual

Study Establishment: INSEAD

No. of awards offered: 1

Application Procedure: Applicants must submit an essay addressing the following question: Give the main reason for your applying for the scholarship and describe your aspirations for your future career development. Scholarship applications may be submitted with the admissions application form. Application forms are available from the website.

Closing Date: February 11th for the September intake of the same year and August 18th for the January intake of the following year Funding: Private

Contributor: Sisley

Additional Information: This scholarship is offered in memory of the late Marc d'Ornano, who lost his life in a car accident while at the start of an excellent career.

\section{INSEAD Swedish Council Scholarship(s)}

Subjects: MBA.

Purpose: To foster the pipeline of international business leaders in Sweden, the Council has created an MBA scholarship at INSEAD to reward such talent. The awards will be merit based, through preference will be given to candidates demonstrating financial need. Eligibility: Candidates must be Swedish nationals and clearly demonstrate an interest for a career linked to business with Sweden. Candidates may not cumulate this award with any other INSEAD or external scholarships. If this is the case, the INSEAD scholarship will be reallocated.

Type: Scholarship

Value: Up to $€ 15,000$ 
Frequency: Annual

Application Procedure: All applications submitted to the INSEAD EI of Hansson Scholarship will be considered.

Closing Date: February 13th each year for the July class (starts in September); August 22nd each year for the December class (starts in January)

Additional Information: Please check website for further information.

\section{INSEAD Syngenta Endowed Scholarship(s) for Emerging} Country Leadership

Eligibility: Candidates must be a national of an emerging economy and have spent a substantial part of their lives in the developing world, in education and/or professional experience. Experience in industry will be considered a plus. Preference will be given to candidates who require proven financial assistance.

Type: Scholarship

Value: $€ 22,500$

No. of awards offered: 2 per class

Application Procedure: Applicants must complete online application and submit their essays.

Closing Date: February 11th for the July class and August 18th for the December class

Additional Information: Please check website for more information.

\section{INSEAD Theo Vermaelen Scholarship}

Subjects: MBA.

Purpose: INSEAD professor, Theo Vermaelen, the Schroders Chaired Professor of International Finance and Asset Management, has chosen to fund one scholarship per year with matched funds from INSEAD for Iraqi participants on the full-time MBA programme at INSEAD. He believes these scholarships will make a small, but hopefully significant contribution to improving the lives of at least a few people from Iraq and that the holder of these scholarships will be their country's leaders in the future.

Eligibility: Candidates must be Iraqi nationals, but not necessarily live in Iraq. Consideration will be given to both merit and financial need.

Type: Scholarship

Value: Up to full-tuition

Frequency: Annual

Closing Date: February 13th, May 10th, August 22nd, October 5th

Additional Information: Please check website for further information.

\section{INSEAD Weston Scholarship(s)}

Purpose: The Garfield Weston Foundation is a U.K.-based, general grant-giving charity endowed by the late W. Garfield Weston and members of his family. The Foundation has helped a wide range of organizations with projects in the Arts, Community, Education, Welfare, Medical, Social, Religion, Youth and Environment. The Garfield Weston Scholarships at INSEAD are based on merit, i.e. the most deserving candidates whether from an academic, career potential or other relevant perspective.

Eligibility: Based on the quality of admission applications (no scholarship application is required) one or two awards will be made per intake. Only candidates who have been admitted in Round 1 and/or Round 2 will be considered.

Type: Scholarship

Value: Up to $€ 15,000$ each

Frequency: Annual

No. of awards offered: Up to 2 per class

Application Procedure: No separate application is required. The holders of the awards will be required to submit an essay on their INSEAD experience at the end of the programme. Notification on the decision: successful candidates will receive the notification on the award approximately 1 week after admission. If you do not receive an email on the award within that time frame please consider that you have not been selected for the Weston scholarship.

Closing Date: No deadline

Additional Information: Please check website for further information.

\section{INSEAD}

\section{South Africa}

Website: http://mba.insead.edu/schlmgmt/dsp_schl_info.cfm? schlcode $=$ AFR02

Contact: INSEAD
INSEAD Nelson Mandela Endowment Scholarships

Subjects: Masters in Business Administration (MBA).

Purpose: To honour the life and work of President Nelson Mandela of South Africa, the INSEAD MBA Class of ' 75 created the INSEAD

Nelson Mandela Endowment Scholarships at their 30th Class Reunion to provide financial support for one or more African participants per year at INSEAD in perpetuity.

Eligibility: To be eligible for the Nelson Mandela Endowed Scholarship, candidates must be a national of a sub-Saharan African country and have spent a substantial part of their lives and received part of their prior education in Africa.

Preference will be given to candidates who require proven financial assistance.

Level of Study: Postgraduate

Type: Scholarship

Value: Up to $€ 20,000$

Country of Study: South Africa

No. of awards offered: 1 or more

Closing Date: April 19th and June 6th

Funding: Government

Contributor: INSEAD

Additional Information: For more details, visit official scholarship website: http://mba.insead.edu/schlmgmt/dsp_schl_info.cfm? schlcode $=$ AFR02

\section{INSTITUT DE RECHERCHE ROBERT-SAUVÉN SANTÉT EN SÉCURITÉ DU TRAVAIL (IRSST)}

505, De Maisonneuve Ouest, Montréal, QC, H3A 3C2, Canada

Tel: (1) 5142881551

Fax: (1) 5142887636

Email: grants@irsst.qc.ca

Website: www.irsst.qc.ca

Institut de recherche Robert-Sauvén santét en sécurité du travail (IRSST), established in Quebec since 1980, is a scientific research organization known for the quality of its work and the expertise of its personnel. The Institute is a private, non-profit agency.

\section{IRSST Graduate Studies Scholarship and postdoctoral Fellowship Program}

Subjects: Occupational health and safety.

Purpose: To support Master's and doctoral students who wish to acquire research training in the occupational health and safety field. Eligibility: Open to students who are registered full-time in a Master's or doctoral programme and have obtained a cumulative average of $\mathrm{B}+$ for all of their undergraduate studies.

Level of Study: Postgraduate, Doctorate

Type: Scholarship

Value: $\$ 14,250$ per year. In addition, a scholarship recipient whose training and research program is outside Canada is reimbursed for the amount exceeding the first $\$ 750$ in annual tuition fees; the cost of travelling to the training and research location, representing the cost of one round-trip economy airplane ticket or one round trip by car, for each year of the effective period of the scholarship (maximum of 2 years)

Length of Study: 2-3 years

Frequency: Annual

Closing Date: July

Contributor: The Commission des normes, de l'équité, de la santé et de la sécurité du travail provides most of the Institute's funding from the contributions it collects from the employers

Additional Information: Please check the website for further details.

For further information contact:

Canada

Tel: (1) 5142881551 ext. 377

Email: bourses@irsst.qc.ca

Contact: Michel Asselin, Research advisor Coordinator of the

Graduate Scholarship Program 


\section{INSTITUT FRANÇAIS D'AMÉRIQUE}

\author{
Department of History, CB\# 3195, Chapel Hill, NC, 27599-3195, \\ United States of America \\ Tel: (1) 9199622115 \\ Fax: (1) 9199621403 \\ Email: IFA@unc.edu \\ Website: http://institut.unc.edu/ \\ Contact: Professor Jay Smith
}

The mission of the Institut Français de Washington is to promote the American study of French culture, language, history and society, and to encourage the work of teachers, scholars and students in these fields. The Institute also sponsors events to foster public understanding of French-American relations. The IFW provides funds for fellowships, prizes, and conferences that serve this mission.

\section{Edouard Morot-Sir Fellowship in French Studies}

Subjects: French studies in the areas of art, economics, history, history of science, linguistics, literature or social sciences.

Eligibility: Open to those in the final stages of a $\mathrm{PhD}$ dissertation or who have held a PhD for no longer than 3 years before the application deadline.

Level of Study: Doctorate, Postdoctorate

Type: Fellowship

Value: US $\$ 1,500$

Length of Study: At least 1 month

Frequency: Annual

Country of Study: France

No. of awards offered: 1

Application Procedure: Applicants must write a maximum of two pages describing the research project and planned trip and enclose a curriculum vitae. A letter of recommendation from the dissertation director is required and a letter from a specialist in the field for assistant professors.

Closing Date: January 15th

Funding: Foundation, private

No. of awards given last year: 3

No. of applicants last year: 90

Additional Information: Awards are for maintenance during research in France and should not be used for travel. Please check website http://institut.unc.edu/application/ for further information. Applications should be sent by email.

For further information contact:

Email: IFA@unc.edu

\section{Gilbert Chinard Fellowships}

Subjects: French studies in the areas of art, economics, history, history of science, linguistics, literature or social sciences.

Eligibility: Open to those in the final stages of a $\mathrm{PhD}$ dissertation or who have held a PhD for no longer than 3 years before the application deadline.

Level of Study: Postdoctorate, Doctorate

Type: Fellowship

Value: US\$1,500

Length of Study: At least 1 month

Frequency: Annual

Country of Study: France

No. of awards offered: 2

Application Procedure: Applicants must write a maximum of two pages describing the research project and planned trip and enclose a curriculum vitae. A letter of recommendation from the dissertation director is also required for $\mathrm{PhD}$ candidates and a letter from a specialist in the field for assistant professors.

Closing Date: January 15th

Funding: Private

No. of awards given last year: 1

No. of applicants last year: 28

Additional Information: Awards are for maintenance during research in France and should not be used for travel. Applications should be sent by email.

For further information contact:

Email: IFA@unc.edu

\section{Harmon Chadbourn Rorison Fellowship}

Subjects: French studies in the areas of art, economics, history, history of science, linguistics, literature or social sciences.

Eligibility: Open to those in the final stages of a $\mathrm{PhD}$ dissertation or who have held a PhD for no longer than 3 years before the application deadline. Level of Study: Doctorate, Postdoctorate, Postgraduate

Type: Fellowship

Value: US $\$ 1,500$

Length of Study: At least 1 month

Frequency: Every 2 years

Country of Study: France

No. of awards offered: 1

Application Procedure: Applicants must write a maximum of two pages describing the research project and planned trip and enclose a curriculum vitae. A letter of recommendation from the dissertation director is required for $\mathrm{PhD}$ candidates and a letter from a specialist in the field for assistant professors.

Closing Date: January 15th

Funding: Foundation, private

No. of awards given last year: 1

No. of applicants last year: 27

Additional Information: Awards are for maintenance during research in France and should not be used for travel. Applications should be sent by email.

For further information contact:

Email: IFA@unc.edu

\section{THE INSTITUT MITTAG-LEFFLER}

\author{
Auravägen 17, SE-18260 Djursholm, Sweden \\ Tel: (46) 86220560 \\ Email: info@mittag-leffler.se \\ Website: www.mittag-leffler.se \\ Contact: Secretarial Office
}

Institut Mittag-Leffler is a Nordic research institute for mathematics, under the auspices of the Royal Swedish Academy of Sciences, created by Gösta and Signe Mittag-Leffler, who donated their house, library and fortune to the Academy in 1916.

\section{Institut Mittag-Leffler Postdoctoral fellowship grants}

Subjects: Mathematics. Programs are of 3, 5 months length (In general January - April, September - December respectively). Eligibility: Open to recent PhDs and advanced graduate students. Preference will be given to applications for long stays.

Level of Study: Graduate, Postdoctorate

Type: Fellowship

Value: 17,000-20,000 Swedish Kronor per month; travel expenses to and from Stockholm, accommodation free of charge and office space Length of Study: There are two different topics during 1 academic year Country of Study: Sweden

No. of awards offered: 8

Application Procedure: In addition to the completed application form, applicants should send a short description of the candidate's research interests and plans, copies of the applicant's papers and preprints and two or (preferably) three letters of recommendation. See the website for further details: www.mittag-leffler.se/programs/1213/ grants.php.

Closing Date: January 12th

Additional Information: Inquiries may be directed to the Institute director, Professor Ari Laptev, director@mittag-leffler.se or, for practical matters, to Programme Administrator Inger Halvarsson, secretary@mittag-leffler.se.

\section{INSTITUTE FOR ADVANCED STUDIES IN THE HUMANITIES}

University of Edinburg, Hope Park Square, Edinburgh, EH8 9NW, Scotland

Tel: (44) 1316504671

Email: iash@ed.ac.uk

Website: www.ed.ac.uk/iash

Contact: Ms Peta Freestone, Administrative Manager 
The Institute for Advanced Studies in the Humanities aims to promote scholarship in the humanities, and, wherever possible, to foster interdisciplinary enquiries. This is achieved by means of fellowships awarded for the pursuit of relevant research and by the public dissemination of findings in seminars, lectures, conferences, exhibitions, cultural events and publications.

\section{David Hume Fellowship}

Subjects: Humanities.

Purpose: To enable research in Edinburgh in any aspect of Hume studies.

Eligibility: Open to Scholars of any nationality holding a doctorate or offering equivalent evidence of aptitude for Advanced studies.

Level of Study: Postdoctorate

Type: Fellowship

Value: $£ 5,000$

Length of Study: 3-4 months

Frequency: Annual

Study Establishment: Institute for Advanced Studies in the

Humanities, University of Edinburgh

Country of Study: United Kingdom

No. of awards offered: 20

Application Procedure: Application form can be downloaded from Institute's website.

Closing Date: February 28th

Funding: Private, trusts

No. of awards given last year: 0

No. of applicants last year: 9

\section{IASH Visiting Research Fellowships}

Subjects: Any discipline within the humanities and social sciences, but priority will be given to those whose work falls within the scope of one of the institute's research themes.

Purpose: To promote advanced research within the field and also to sponsor interdisciplinary research.

Eligibility: Open to scholars of any nationality holding a doctorate or offering equivalent evidence of aptitude for advanced studies.

Level of Study: Postdoctorate

Type: Fellowship

Length of Study: 2-6 months

Frequency: Annual

Study Establishment: The Institute for Advanced Studies in the Humanities at the University of Edinburgh

Country of Study: United Kingdom

No. of awards offered: 15

Application Procedure: Applicants must complete an application form, available from the Institute. Candidates should advise their referees to write on their behalf directly to the Institute. A minimum of two and a maximum of three references are required. At least one referee should come from outside the institution of the applicant.

Closing Date: February 28th

Funding: Private

No. of awards given last year: 15

No. of applicants last year: 33

Additional Information: Fellows have a private office at the Institute, near the library and within easy reach of the National Library of Scotland, the Central City Library, the National Galleries and Museums, the Library of the Society of Antiquaries in Scotland and the National Archives of Scotland. Only fully completed applications will be considered. It is the responsibility of each applicant to ensure that all documentation is complete, and that referees submit their reports to the Institute by the closing date.

\section{IASH-SSPS Visiting Research Fellowships}

Subjects: Social and political science.

Purpose: To encourage outstanding research, international scholarly collaboration and networking activities.

Eligibility: Open to scholars of any nationality holding and doctorate or equivalent professional qualification.

Level of Study: Postdoctorate

Type: Fellowship

Value: Unfunded. Some sub-schemes within this programme offer travel and subsistence assistance. Check IASH website for details Length of Study: 2-4 months

Frequency: Annual
Study Establishment: Institute for Advanced Studies in the Humanities, University of Edinburgh

Country of Study: United Kingdom

No. of awards offered: Varies

Application Procedure: Application form available on Institute's website.

Closing Date: February 28th

Funding: Private

No. of awards given last year: 6

No. of applicants last year: 11

Additional Information: Fellows will be expected to work in collaboration with one or more member of School of Social and

Political Science, University of Edinburgh.

\section{Postdoctoral Bursaries}

Subjects: Humanities and social sciences.

Purpose: To support candidates in any area of the Humanities and Social Sciences, whose work falls within the scope of one of the Institute for Advanced Studies current research themes or across disciplinary boundaries in the Humanities.

Eligibility: Applicants must have been awarded a doctorate, normally within the last 3 years, and should not have held a permanent position at a university, or a previous fellowship at the Institute for Advanced Studies. Those who have held temporary and/or short-term appointments are eligible to apply.

Level of Study: Postdoctorate

Type: Bursary

Value: Up to $£ 10,000$

Length of Study: 3-9 months

Frequency: Annual

Study Establishment: Institute for Advanced Studies in the

Humanities, University of Edinburgh

Country of Study: Scotland

No. of awards offered: $10-14$

Application Procedure: Application form can be downloaded from the Institute's website.

Closing Date: April 30

Funding: Trusts

No. of awards given last year: 13

No. of applicants last year: 94

Additional Information: In order to take full advantage of the seminars and lectures which take place during the semesters and to meet with staff in the College of Humanities and Social Science, applicants are encouraged to apply for periods that will include at least part of one of the semesters. Check website for further details

\section{INSTITUTE FOR ADVANCED STUDIES ON SCIENCE, TECHNOLOGY AND SOCIETY (IAS-STS)}

\author{
Kopernikusgasse 9, Graz, 8010, Austria \\ Tel: (43) 31681390934 \\ Fax: (43) 316810274 \\ Email: info@sts.tugraz.at \\ Website: www.sts.tugraz.at \\ Contact: Günter Getzinger, Acting Director
}

In 1999 the Inter University Research Centre for Technology, Work and Culture (IFZ) launched the IAS-STS in Graz, Austria. It promotes the interdisciplinary investigation of the links and interaction between science, technology and society as well as research on the development and implementation of socially and environmentally sound, sustainable technologies.

\section{IAS-STS Fellowship Programme}

Subjects: Gender (technology and environment), technology studies, information and communication technologies and society, technology assessment, participatory technology design, sustainable consumption and production, genetics and biotechnology, energy and climate. Purpose: To give the students the opportunity to explore issues. Eligibility: Applicants must hold an academic degree.

Level of Study: Doctorate, Postdoctorate, Postgraduate, Research

Type: Fellowships

Value: $€ 940$ per month 
Length of Study: Up to 9 months

Frequency: Annual

Study Establishment: IAS-STS

Country of Study: Austria

No. of awards offered: 5

Application Procedure: Application forms can be download from the website.

Closing Date: June 30th

Funding: Government

Contributor: Styrian Government

No. of awards given last year: 5

No. of applicants last year: 50

\section{THE INSTITUTE FOR CLINICAL SOCIAL WORK}

401 South State Street, Suite 822, Chicago, IL, 60605,

United States of America

Tel: (1) (312) 9354232

Fax: (1) (312) 9354255

Email: info@icsw.edu

Website: www.icsw.edu

Contact: Mr John Dowdy, Manager of Strategic Operations and Financial Aid

\section{Elizabeth Jacobs Scholarship}

Subjects: Clinical social work.

Purpose: To support promising students who are dedicated to working with families challenged by poverty, immigration or trauma. Eligibility: Open to full time students who have successfully completed their first year of studies, who have financial need and have been nominated by faculty.

Level of Study: Doctorate

Type: Scholarship

Value: Varies

Frequency: Annual

Study Establishment: The Institute for Clinical Social Work

Country of Study: United States of America

No. of awards offered: Varies

Application Procedure: Applicants must contact the financial aid administrator.

\section{INSTITUTE FOR HUMANE STUDIES (IHS)}

3434 Washington Blvd. MS 1C5, Arlington, VA, 22201, United States of America

Tel: (1) 7039934880

Fax: (1) 7039934890

Email: abrand@gmu.edu

Website: www.theihs.org

Contact: Ms Amanda Bland, Director of Academic Programs

The Institute for Humane Studies (IHS) is a unique organization that assists graduate students worldwide with a special interest in individual liberty. IHS awards over US $\$ 400,000$ a year in scholarships to students from universities around the world. They also sponsor the attendance of hundreds of students at free summer seminars and provide various forms of career assistance. Through these and other programmes, IHS and a network of faculty associates promote the study of liberty across a broad range of disciplines, encouraging understanding, open enquiry, rigorous scholarship and creative problem-solving.

\section{Hayek Fund for Scholars}

Subjects: Social sciences, law, the humanities, journalism.

Purpose: To help offset expenses for participating in professional conferences and job interviews.

Eligibility: Open to graduate students and untenured faculty members and postdoctoral students.

Level of Study: Postgraduate

Value: US $\$ 750$

Frequency: Annual

Country of Study: Any country

Application Procedure: For application requirements visit the website.
Closing Date: Applications for the Hayek Fund must be submitted online at least 4 weeks in advance of your activity

Additional Information: You will need an IHS account to apply. You may save your application and return later to submit it.

For further information contact:

George Mason University, 4400 University Drive, Fairfax, VA, 22030, United States of America

Tel: (1) 7033231055

Fax: (1) 7034251536

Contact: Keri Anderson, Programme Director

\section{IHS Humane Studies Fellowships}

Subjects: A variety of fields, including economics, philosophy, law, political science, history, and sociology.

Purpose: To support outstanding students with a demonstrated interest in the classical liberal tradition intent on pursuing an intellectual and scholarly career.

Eligibility: Open to graduate students who have enroled for the next academic year at accredited colleges and universities.

Level of Study: Graduate, Postgraduate

Type: Fellowship

Value: $\$ 2,000-15,000$

Frequency: Annual

Country of Study: Any country

Application Procedure: Applicants must complete and submit an application form with three completed evaluations, three essays, official test scores, official transcripts and a term paper or writing sample. Applications can be downloaded at www.theihs.org/hsf.

Closing Date: December 31st

Funding: Private

No. of awards given last year: 195

\section{IHS Summer Graduate Research Fellowship}

Subjects: The humane sciences, e.g. history, political and moral philosophy, political economy, economic history, legal and social theory. Purpose: To give students who share an interest in scholarly research in the classical liberal tradition the opportunity to work on a thesis chapter or a paper of publishable quality and to participate in interdisciplinary seminars under the guidance of a faculty supervisor. Eligibility: Open to graduate students in the humanities, social sciences and law who intend to pursue academic careers and who are currently pursuing research in the classical liberal tradition.

Level of Study: Doctorate, Graduate, Postgraduate

Type: Fellowship

Value: $\$ 5,000$ stipend plus a travel and housing allowance to attend the two conferences

Frequency: Annual

Country of Study: United States of America

No. of awards offered: 8-10

Application Procedure: Applicants must submit a proposal, curriculum vitae, a copy of Graduate Record Examination scores or Law School Admission Test scores and transcripts, a writing sample and reference details. Visit the website for further information.

Closing Date: February 15th

Funding: Private

Additional Information: The opportunity to apply is by invitation only Please see the website www.theihs.org/summer-graduate-researchfellowships for further details.

\section{THE INSTITUTE FOR SUPPLY MANAGEMENT (ISM)}

\author{
2055 E. Centennial Circle, Tempe, AZ, 85285-2160, \\ United States of America \\ Tel: (1) 4807526276 \\ Fax: (1) 4807527890 \\ Email: ssturzl@ism.ws \\ Website: www.ism.ws \\ Contact: Valerie Gryniewicz, Manager, Education
}

The Institute for Supply Management (ISM) is a non-profit association that provides national and international leadership in purchasing and supply management research and education. ISM provides more than 40,000 members with opportunities to expand their professional skills and knowledge. 


\section{ISM Dissertation Research Grant}

Subjects: Purchasing materials and supply management.

Purpose: To financially assist individuals in preparation for a career in the field, for university teaching and to encourage research.

Eligibility: Open to doctoral candidates who are pursuing a $\mathrm{PhD}$ or DBA in purchasing, business, logistics, management, economics, industrial engineering or a related field and who are at the dissertation stage. Applicants must be enroled in an accredited U.S. university are eligible for the award.

Level of Study: Doctorate

Type: Grant

Value: Up to US $\$ 12,000$

Frequency: Annual

Country of Study: United States of America

No. of awards offered: Up to 4

Application Procedure: (1) Letter of application, signed by the candidate. (2) Official transcripts from the candidate's current university. (3) Proposal abstract, maximum 25 pages, including a literature search and a research design. The proposal must specifically discuss problem statement or hypothesis; research methodology, including data sources, collection, and analysis; significance/value of the research in purchasing/supply management. (4) A letter from the candidate's major advisor, stating that the dissertation topic is acceptable. (5) Three letters of recommendation (one letter may serve as the letter requested in \#4 above) from professors or administrators familiar with the applicant's research capabilities. The letters should be sealed independently within the application package. (6) A curriculum vitae, which may include a list of research in progress, accomplishments in academe, honors, awards, and relevant work experience. The ISM Doctoral Grant Program seeks to notify all applicants by mid-June whether they received a grant. Please check at www.ism.ws/education/content.cfm?ltemNumber $=791$ for detailed information.

Closing Date: January 31 st

Funding: Private

Contributor: ISM

No. of awards given last year: 3

No. of applicants last year: 20

Additional Information: Upon successful completion of the research, the ISM will be interested in the publication of material from the study. Nominations are invited from departments of economics, management, marketing and business administration at U.S. universities offering a doctoral degree in appropriate fields.

\section{INSTITUTE FOR WORK AND HEALTH}

481 University Avenue Suite 800, Toronto, ON, M5G 2E9, Canada Tel: (1) 4169272027

Fax: (1) 4169274167

Email: info@iwh.on.ca

Website: www.iwh.on.ca

Institute for Work and Health is an independent, non-profit research organization whose mission is to conduct and share research with workers, labourers, employers, clinicians and policy makers to promote, protect and improve the health of working people.

\section{S. Leonard Syme Training Fellowships in Work and Health}

Subjects: Work and health.

Purpose: To financially support young researchers at the Master's or doctoral level who intend studying in the field of work and health. Eligibility: Open to candidates who are enroled at an Ontario university that has a formal affiliation with the Institute for Work \& Health. Candidates who are part-way through their programme of study will also be considered. Preference will be given to candidates whose research interests include understanding the social determinants of health and illness in work environments, and/or evaluating workplace interventions to improve health and/or the associated measurement issues.

Level of Study: Postgraduate, Doctorate

Type: Fellowship

Value: Major award of up to $\$ 15,000$ and a minor award of up to $\$ 5,000$

Length of Study: 1 year
Frequency: Annual

Study Establishment: Several universities

Country of Study: Canada

Application Procedure: Applicants must provide a completed

application form, a 300-word statement of their research interests and a 200-word statement of their career objectives, a reference letter and curriculum vitae. Application form is available online.

Closing Date: June 2nd

Additional Information: Please check website (www.iwh.on.ca/ syme) for availability and latest updates.

For further information contact:

Website: www.iwh.on.ca

Contact: Ms Lyudmila Marsurova

\section{INSTITUTE OF ADVANCED LEGAL STUDIES (IALS)}

Institute of Advanced Legal Studies, Charles Clore House, 17 Russell Square, London, WC1B 5DR, England Tel: (44) 02078625800

Fax: (44) 02078625850

Email: ials.administrator@sas.ac.uk

Website: www.ials.sas.ac.uk

Contact: Margaret Wilson, Institute Manager

The Institute of Advanced Legal Studies (IALS) plays a national and international role in the promotion and facilitation of legal research. It possesses one of the leading research libraries in Europe and organizes a regular programme of conferences, seminars and lectures. It also offers postgraduate taught and research programmes and specialized training courses.

\section{IALS Visiting Fellowship in Law Librarianship}

Subjects: Law and library science.

Purpose: To enable experienced law librarians, who are undertaking research in, appropriate fields, to relate their work to activities in which the Institutes own library is involved.

Eligibility: Open to experienced law librarians from any country. Level of Study: Unrestricted

Type: Fellowship

Value: Fellowships can consist of or include a period working with Institute library staff or be a period of research based in a research carrel

Length of Study: Between 2 and 6 months

Frequency: Annual

Study Establishment: The IALS

Country of Study: United Kingdom

No. of awards offered: 1

Application Procedure: Applicants must submit a full curriculum vitae, the names, addresses and telephone numbers of two referees and a brief statement of the research programme to be undertaken to the Administrative Secretary.

Closing Date: Applications may be considered at any time of the year No. of awards given last year: 1

No. of applicants last year: 1

\section{IALS Visiting Fellowships}

Subjects: Law: legal skills, legal profession, legal education, legal implementation studies, company and commercial law, financial services law, access to legal information.

Purpose: Visiting fellowships are designed for persons already established in their own field of activity who are undertaking work within fields covered by or adjacent to the Institute's own research programmes or interests.

Eligibility: Open to nationals of any country who are established legal scholars and are undertaking research in appropriate fields.

Level of Study: Unrestricted

Type: Fellowship

Value: Non-stipendary

Length of Study: A minimum of 3 months and a maximum of 1 year

Frequency: Annual

Study Establishment: The IALS

Country of Study: United Kingdom

No. of awards offered: Up to 6 
Application Procedure: Applicants must submit a full curriculum vitae, the names, addresses and telephone numbers of two referees and a brief statement of the research programme to be undertaken. Closing Date: January 30th for the following academic year

No. of awards given last year: 7

No. of applicants last year: 16

Additional Information: This award is not available for postgraduate research.

\section{THE INSTITUTE OF CANCER RESEARCH (ICR)}

Genetic Epidemiology Building, 15 Cotswold Road, Belmont, Sutton, Surrey, SM2 5NG, England

Tel: (44) 02086438901 ext. 4253 Fax: (44) 02086436940

Email: emma.pendleton@icr.ac.uk Website: www.icr.ac.uk

Contact: Sarah Goodwin, Registry Project Manager

Over the past 100 years, the Institute of Cancer Research (ICR) has become one of the largest, most successful and innovative cancer research centres in the world. The Institute and the Royal Marsden NHS Trust exist side by side in Chelsea and on a joint site at Sutton, and this close association allows for maximum interaction between fundamental laboratory work and clinical environment.

\section{ICR Studentships}

Subjects: Cancer research.

Purpose: Research degree studentships.

Eligibility: First class or upper second class undergraduate degree required in a relevant subject. Overseas equivalent level: experience of lab or research work, a TOEFL score of 650 or IELTS score of $7.0-$ or equivalent language assessment.

Level of Study: Postdoctorate, Doctorate

Type: Studentship

Value: $£ 19,500$ (inner London - Chester Beatty Laboratories, Fulham Road) or £18,180 (outer London - Sutton Campus), is increased annually in-line with the increase in cost-of-living

Length of Study: Up to 4 years

Frequency: Annual

Study Establishment: The Institute of Cancer Research, University of London

Country of Study: United Kingdom

No. of awards offered: $20-30$

Application Procedure: See website www.icr.ac.uk/phds.

Funding: Government, trusts

Contributor: Cancer Research UK/Wellcome Trust, Medical Research Council

No. of awards given last year: 28

No. of applicants last year: 300

Additional Information: A limited number of Institute postdoctoral fellowships are offered from time to time as vacancies occur.

\section{INSTITUTE OF CURRENT WORLD AFFAIRS}

1779 Massachusetts Ave. NW, Suite 615, Washington, DC, 2003 United States of America

Tel: (1) 2023644068

Fax: (1) 2023640498

Email: icwa@icwa.org

Website: www.icwa.org

Contact: Steven Butler, Executive Director

\section{Institute of Current World Affairs Fellowships}

Subjects: International affairs.

Purpose: To enable young adults of outstanding promise and character to study and write about areas or issues of the world outside the USA.

Eligibility: Open to individuals up to the age of 36 who have finished their formal education. Applicants must have a good command of spoken and written English, and have 'completed the current phase of their formal education' before the date of application.
Level of Study: Professional development, Postgraduate Type: Fellowship

Value: The Institute provides fellows with sufficient funding to allow them and their families to live comfortably and in good health

Length of Study: Minimum 2 years

Country of Study: Any country

No. of awards offered: 2

Application Procedure: Applicants must write to the Executive Director and briefly explain their personal background and the professional experience that would qualify them in the Institute's current areas of concern, details of which are available upon request They should also describe the activities they would like to carry out during the 2 years overseas. This initial letter is followed by a more detailed written application process and must be completed prior to the deadline.

Closing Date: March 1st, September 1st

Funding: Private

Additional Information: Fellowships are not awarded to support work toward academic degrees nor to underwrite specific studies or research projects. The Institute is also known as the Crane-Rogers Foundation.

\section{THE INSTITUTE OF EAST ASIAN STUDIES (IEAS)}

University of California, 2223 Fulton Street \#2318, Berkley, CA, 94720-2318, United States of America Tel: (1) 5106422809

Email: ieas@berkeley.edu

Website: http://ieas.berkeley.edu/

The Institute of East Asian Studies (IEAS) is an Organized Research Unit that serves as the focal point for all of UC Berkeley programs related to East Asia and the Pacific. Frequently ranked first in depth and breadth among all such programs in the nation, East Asian Studies at Berkeley is a unique national resource and an invaluable asset for California and the West Coast.

\section{IEAS Graduate Fellowships in East Asian Studies in USA}

Subjects: Fellowships are provided in the field of East Asian Studies.

Purpose: IEAS will accept applications for most academic purposes including pre-dissertation research or study, dissertation research, dissertation write-up awards, etc.

Eligibility: IEAS will consider applications from students whose research goes beyond the boundaries of one country or region. Regions may include China, Japan, Korea, and their neighbors in Northeast Asia, Central Asia, Southeast Asia, or beyond. Students whose work focuses on only a single country should apply to the appropriate Center. Single-country applications received by IEAS may be referred to the Center for Chinese, Japanese, or Korean Studies. For detailed information, please visit website.

Level of Study: Research

Type: Fellowship

Value: Full awards are in the $\$ 1,500-3,500$ range. Smaller awards (up to $\$ 600$ ) may also be available.

Country of Study: United States of America

Application Procedure: The mode of applying is by mail or post. The required documents are: application cover sheet; a current curriculum vitae; a current transcript (unofficial copies) from UCB together with a list of any courses currently in progress; a list of all financial assistance received during graduate study, including fellowships from all sources (extramural fellowships as well), research assistantships, teaching appointments, and grants; a complete list of all support, including the amount of funds requested for the coming academic year, with notes on the status of the requests; a detailed research/study proposal for the period of requested support (max. 2 pages); an estimated budget for the project; two letters of recommendation.

Closing Date: April 1st

Contributor: The Centers for Chinese Studies (CCS), Japanese Studies (CJS) and Korean Studies (CKS) and the Institute of East Asian Studies (IEAS)

Additional Information: Awards will be announced in late April. 


\section{INSTITUTE OF EDUCATION}

20 Bedford Way, London, WC1H OAL, England Tel: (44) 02076126000

Email: info@ioe.ac.uk

Website: www.ioe.ac.uk

Contact: Josie Charlton, Head of Marketing and Development

Founded in 1902, the Institute of Education is a world-class centre of excellence for research, teacher training, higher degrees and consultancy in education and education-related areas of social science. Our pre-eminent scholars and talented students from all walks of life make up an intellectually rich and diverse learning community.

\section{Nicholas Hans Comparative Education Scholarship} Subjects: Comparative education.

Purpose: To assist a well-qualified student to study for a $\mathrm{PhD}$ in comparative education at the Institute of Education.

Eligibility: Candidates must be registered Institute students not normally resident in the UK.

Level of Study: Doctorate

Type: Scholarship

Value: Full-time tuition fees

Length of Study: 3-7 years

Frequency: Annual

Study Establishment: Institute of Education

Country of Study: United Kingdom

No. of awards offered: 1

Application Procedure: Candidates are required to submit an extended essay of 25,000-30,000 words, based upon their research or proposed research, that exemplifies, extends or develops by critique the concerns of Nicholas Hans in comparative education.

Closing Date: June 1st

Funding: Trusts

Contributor: Trust fund based upon money left in the will of Nicholas Hans' widow

For further information contact:

Email: p.kelly@ioe.ac.uk

Contact: Patricia Kelly

\section{INSTITUTE OF EUROPEAN HISTORY}

\author{
Alte Universitätsstrasse 19, D-55116 Mainz, Germany \\ Tel: (49) 61313939350 \\ Fax: (49) 61313935326 \\ Email: ieg4@ieg-mainz.de \\ Website: www.ieg-mainz.de \\ Contact: Dr Denise Kratzmeier
}

The Institute of European History in Mainz, founded in 1950, is dedicated to the promotion of interdisciplinary historical research that focuses on European communication and transfer processes since 1450. Its research groups and international fellows focus on the interplay of religious, political and social phenomena relating to these processes.

\section{Leibniz Institute of European History Fellowships}

Subjects: Research on the historical foundations of Europe from early modern period to contemporary history, particularly their religion, political and social dimensions. Projects dealing with European communication and transfer processes or project focusing on theology, church history and intellectual history are particularly welcome.

Purpose: To support young scientists in the completion of their doctoral work or in the execution of shorter postdoctoral projects. Participation in the Institute's research groups is particularly welcome. Eligibility: Doctoral Fellowships are open to holders of a Master's degree and to Fellows in the advanced stages of graduate work in history, theology or other historical subjects. Applicants must have successfully completed their comprehensive oral examinations. Postdoctoral Fellowships are open to applicants who have completed PhD.

Level of Study: Doctorate, Postdoctorate

Type: Fellowship
Value: A monthly stipend

Length of Study: 6-12 months

Frequency: Annual

Study Establishment: The Leibniz Institute of European History

Country of Study: Germany

No. of awards offered: $10-30$ doctoral fellowships and 2 postdoctora fellowships

Application Procedure: Applicants must contact the directors of the institute. For the application form, details and deadlines see the website: www.ieg-mainz.de/stipendienprogramm. Please use the application form including curriculum vitae, list of publications and a description of PhD thesis. Copies of university transcripts and two letters of support are additionally required.

Closing Date: February and August

Funding: Government

No. of awards given last year: 20

No. of applicants last year: 100

Additional Information: Please see the website for more details.

\section{INSTITUTE OF FOOD TECHNOLOGISTS} (IFT)

\author{
525 W. Van Buren, Suite 1000, Chicago, IL, 60607, \\ United States of America \\ Tel: (1) 3127828424 \\ Fax: (1) 3127828348 \\ Email: info@ift.org \\ Website: www.ift.org \\ Contact: Dr Robert A. Vitas
}

The Institute of Food Technologists (IFT), founded in 1939, is a nonprofit scientific society with 29,000 members working in food science, technology and related professions in industry, academia, and government. IFT's mission is to advance the science and technology of food through the exchange of knowledge. As a society for food science and technology, IFT brings a scientific perspective to the public discussion of food issues.

\section{IFT Foundation Graduate Scholarships}

Subjects: Food technology and food science.

Purpose: To encourage and support outstanding research.

Eligibility: Open to current graduates pursuing a course of study leading to an $\mathrm{MS}$ or $\mathrm{PhD}$ degree. Candidates must possess an aboveaverage interest in research together with demonstrated scientific aptitude. Candidates must have at least a 3.0 cumulative GPA Candidates must be a student member of IFT at the time of application.

Level of Study: Doctorate, Graduate, Postgraduate

Type: Scholarship

Value: Varies

Frequency: Annual

Study Establishment: Any educational institution that is conducting fundamental investigations in the advancement of food science and technology

Country of Study: United States of America or other countries if appropriate

Application Procedure: Applicants must visit IFT foundation website for details.

Closing Date: April 2nd

Funding: Commercial, individuals, private

Contributor: Contributors include General Mills, Inc., Edlong Dairy

Flavors, Nutraceuticals and Functional Foods Division, Education Division, Food Laws and Regulation Division, and Proctor \& Gamble Company

\section{Marcel Loncin Research Prize}

Subjects: Chemistry/Physics/Engineering research applied to food processing and the improvement of food quality.

Purpose: To provide funds for research in food processing and the improvement of food quality.

Eligibility: Open to all individuals who are capable of conducting research.

Level of Study: Research

Type: Prize 
Value: US $\$ 50,000$ and a plaque

Frequency: Bi-annual

Application Procedure: A completed application form accompanied by a grant proposal and a biographical sketch must be submitted.

Closing Date: December 1st

Funding: Foundation

Contributor: Institute of Food Technologists

\section{INSTITUTE OF FUNDAMENTAL SCIENCES, MASSEY UNIVERSITY}

\author{
Institute of Fundamental Sciences, Massey University, \\ Palmerston North, New Zealand \\ Email: r.mclachlan@massey.ac.nz \\ Contact: Professor Robert McLachlan
}

The Institute of Fundamental Sciences is based at Massey University's Palmerston North, Manawatû campus. Our multi- and interdisciplinary research and teaching span the fundamental areas of chemistry, physics, nanoscience, mathematics, statistics, biochemistry, microbiology, genetics, plant science, evolutionary biology and bioinformatics.

\section{Massey Business School - PhD scholarships}

Subjects: Agrifood business, finance and financial services, innovation and entrepreneurship.

Purpose: The Massey Business School is seeking to strengthen its strategic research platforms.

Eligibility: At a minimum, you must meet MU admission criteria: GPA of 7.5 or higher (on a 9 point scale). This is above an average grade of A- (an MBA is not a direct pathway to a PhD).

Level of Study: Doctorate

Type: Scholarship

Value: NZ $\$ 25,000$ per year for a maximum of 3 years

Length of Study: 3 years

Study Establishment: Institute of Fundamental Sciences, Massey University

Country of Study: New Zealand

No. of awards offered: 8

Application Procedure: You need to submit your academic CV, academic transcripts, a one-page research proposal and other supporting documents to the appropriate person listed: School of Accountancy: Dr Lin Mei Tan L.M.Tan@massey.ac.nz. School of Aviation: Dr Andrew Gilbey A.P.Gilbey@massey.ac.nz. School of Economics \& Finance: Fong Mee Chin F.M.Chin@massey.ac.nz. School of Communication, Journalism \& Marketing: Claudia Silva C.Silva@massey.ac.nz. School of Management: Brigid Eames B.Eames@massey.ac.nz. General enquiry: Carnette Pulma C.Pulma@massey.ac.nz.

Closing Date: October 1st and March 1 st

\section{PhD Opportunity - Engineering}

Subjects: Physics or engineering.

Eligibility: The successful candidate will likely have a background in physics or engineering and will provide evidence of well-developed mathematical skills and practical ability.

Level of Study: Doctorate

Type: Stipendary

Value: The project will be carried out with an industrial partner (Ravensdown) and a stipend is offered for a duration of 3 years Length of Study: 3 years

Study Establishment: Institute of Fundamental Sciences, Massey University

Country of Study: New Zealand

Application Procedure: Applicants should provide their CV to

Professor Clive Davies C.Davies@massey.ac.nz, School of

Engineering and Advanced Technology.

\section{PhD Scholarship (Calcium ion channels and the skeleton)}

Eligibility: A sound background in physiology, biochemistry or molecular biology. Bachelor's degree with suitable Honours or a Master's degree. GPA of at least 7.5 out of $9\left(A_{-}\right)$based on their last 2 years of study. Excellent written and oral communication skills.
Level of Study: Doctorate

Type: Scholarship

Value: A tax-free living allowance of NZ $\$ 25,000$ per year for 3 years. The candidate will be responsible for university tuition fees

Length of Study: 3 years

Study Establishment: Massey University

Country of Study: New Zealand

Application Procedure: Please email your CV, academic transcripts the names of at least two academic references and a cover letter outlining your interest in this project along with why you are suited to this PhD, to Dr Wei-Hang Chua (w.h.chua@massey.ac.nz).

Closing Date: March 10th

Additional Information: Suitable candidates must meet the entry requirements for enrolling in a $\mathrm{PhD}$ at Massey University: www. massey.ac.nz/massey/research/higher-research-degrees/how-to-apply-for-the-phd/are-you-qualified-and-ready-for-the-phd/are-you-qualified-and-ready-for-the-phd_home.cfm. Non-native English speakers will need to fulfill the academic language requirements for postgraduate study at Massey University. See: www.massey.ac.nz/ massey/international/study-with-massey/entry-requirements/ entry-requirements_home.cfm.

\section{PhD Scholarship (Drug Research Team, SHORE \& Whariki Research Centre)}

Level of Study: Doctorate

Type: Scholarship

Value: NZ \$25,000 per year (tax free) plus tuition fees

Length of Study: 3 year

Frequency: Annual

Country of Study: New Zealand

Application Procedure: To apply please send a covering letter, curriculum vitae and 3 recent examples of your written work via email to Dr Chris Wilkins. If you would like to discuss this opportunity further please contact Dr Chris Wilkins (c.wilkins@massey.ac.nz).

Closing Date: March 20th

\section{PhD Scholarship in Mathematics}

Subjects: Mathematics (geometric numerical integration).

Eligibility: Applicants should have or expect to receive a BSc (Hons) or MSc degree or equivalent in mathematics.

Level of Study: Doctorate

Type: Scholarship

Value: The scholarship covers all tuition fees for international and domestic students and includes a tax-free stipend of NZ\$25,000 per year

Study Establishment: Institute of Fundamental Sciences, Massey University

Country of Study: New Zealand

Application Procedure: Applications including a CV, academic transcript and cover letter should be sent to Professor Robert McLachlan, Institute of Fundamental Sciences, Massey University, Palmerston North, New Zealand or by email to r.mclachlan@massey. ac.nz.

Additional Information: See web site dynamics.massey.ac.nz for further information.

\section{School of Engineering and Advanced Technology scholarships}

Eligibility: To be eligible you must hold a recognized entrance qualification.

Level of Study: Doctorate

Type: Scholarship

Value: $\$ 25,000$ a year for 3 years, to cover fees and living expenses

Length of Study: 3 years

Frequency: Annual

Study Establishment: Institute of Fundamental Sciences, Massey University

Country of Study: New Zealand

No. of awards offered: 4

Application Procedure: Initial applications should be on the Massey University form. Please send the form to Michele Wagner (m.wagner@massey.ac.nz), not the college coordinator

Closing Date: November each year 


\section{INSTITUTE OF HISTORICAL RESEARCH (IHR)}

University of London, Senate House, Malet Street, London, WC1E $7 \mathrm{HU}$, England

Tel: (44) 02078628740

Fax: (44) 02078628745

Email: ihr.reception@sas.ac.uk

Website: www.ihr.sas.ac.uk Contact: Director

The Institute of Historical Research (IHR) is a centre for advanced study in history. It is the meeting place for scholars from around the world, housing the largest open access collection of primary sources for historians in the UK, administering research and providing courses, seminars and conferences.

\section{The Annual Pollard Prize}

Purpose: The Pollard Prize is awarded annually for the best paper presented at an Institute of Historical Research seminar by a postgraduate student or by a researcher within 1 year of completing the PhD.

Eligibility: Applicants are required to have delivered a paper at an IHR seminar during the academic year in which the award is made. Papers should be fully footnoted, although it is not necessary at this stage to follow Historical Research house style. All papers submitted must be eligible for publication.

Level of Study: Research, Postdoctorate

Type: Prize

Value: Fast track publication in the prestigious IHR journal, Historical Research, and $£ 200$ of Blackwell books. A variable number of runner up prizes will be awarded, depending on the quality of applications in any given year

Frequency: Annual

Application Procedure: Submissions should be supported by a reference from a convenor of the appropriate seminar.

Closing Date: May 30th

No. of awards given last year: 1

\section{Conrad and Elizabeth Russell Postgraduate Emergency Hardship Fund}

Subjects: History.

Purpose: The Conrad and Elizabeth Russell Postgraduate Emergency Hardship Fund exists to support PhD candidates (in History) who meet with sudden and unexpected hardship.

Eligibility: Applicants should meet all the following criteria: Have met with sudden and unexpected hardship. Be members of the IHR community (usually defined as being either a regular attender at IHR seminars or a regular user of the IHR as a reader). Be registered for a $\mathrm{PhD}$ in History at a British or North American university. Be resident in London, whether temporarily for the purposes of their research or as their normal place of residence. London is broadly defined as within the Greater London area. Have applied (wherever possible) to their own university or college for assistance before turning to the fund.

Level of Study: Doctorate

Type: Funding support

Value: $£ 1,000$ will normally be available for distribution during any

1 year and an individual student will not normally receive an award of more than $£ 500$

Frequency: Dependent on funds available

Application Procedure: Applicants must submit an application form. Closing Date: July 31 st

\section{The Huguenot Scholarship}

Subjects: The study of any activity of the French, the Dutch, the Flemish or the Walloon Protestants from the 16th century to the present, in any geographical area. 'Activity' will be interpreted in the widest sense.

Purpose: The award will be made to a student working for a higher degree on a Huguenot subject.

Eligibility: Applicants may be of any nationality or academic affiliation, but they must be registered for a postgraduate degree in History, or a closely related subject.

Level of Study: Research

Type: Scholarship

Value: $£ 2,500$
Frequency: Annual

Application Procedure: Candidates should ensure that they supply, in addition to their application form, two confidential references from academic referees in sealed envelopes.

Closing Date: July 1st

Funding: Trusts

IHR Bursaries (IHR Friends, Alwyn Ruddock, David Bates)

Purpose: Applications are invited from doctoral students registered at universities in the UK for bursaries to undertake research trips to London archives.

Eligibility: The bursaries are intended for students who are not registered at London-based institutions and who do not live within

Greater London.

Level of Study: Doctorate, Research

Type: Bursary

Value: Up to $£ 500$

Frequency: Annual

Application Procedure: Applicants must submit an application form. Closing Date: July 7 th

\section{Isobel Thornley Research Fellowship}

Subjects: Medieval history, modern history or contemporary history. Purpose: To help candidates at an advanced stage of a PhD to complete their doctorates.

Eligibility: Open to nationals of any country, but only to those who are registered for a $\mathrm{PhD}$ at the University of London.

Level of Study: Doctorate

Type: Fellowship

Value: UK£10,000

Length of Study: 1 year

Frequency: Dependent on funds available

Study Establishment: IHR

Country of Study: United Kingdom

No. of awards offered: 1

Application Procedure: Applicants must complete an application form, available from the Fellowship Assistant in early January.

Closing Date: March 4th

Funding: Private

Contributor: Isobel Thornley Bequest

No. of awards given last year: 1

No. of applicants last year: 80

\section{Jacobite Studies Trust Fellowship}

Subjects: Research into the Stuart Dynasty in Britain and Ireland, and in exile, from the departure of James II in 1688 to the death of Henry Benedict Stuart in 1807.

Purpose: To support 6 months of postdoctoral research into any aspect of Jacobite History.

Eligibility: Open to Doctorate students with academic excellence and depending on the candidate's contribution to the field. Open without regard to nationality or academic affiliation.

Level of Study: Postdoctorate

Type: Fellowship

Value: $£ 7,500$

Length of Study: 6 months

Frequency: Annual

No. of awards offered: 2

Application Procedure: Details at www.history.ac.uk/awards.

Closing Date: April 20th

Funding: Trusts

Contributor: Jacobite Studies Trust

\section{The Parliamentary History Prize}

Subjects: The parliamentary history of Britain, England and Wales, Ireland, Scotland or British colonial assemblies.

Purpose: The award is offered for the best essay submitted on any aspect of the parliamentary history of Britain, England and Wales, Ireland, Scotland or British colonial assemblies.

Eligibility: Candidates must normally not at the date of submission be over the age of 35 (exception may be made for candidates with unusual academic curriculum vitaes), and must submit a brief essay with their entry. The essay must be a genuine work of original research, not hitherto published or accepted for publication. Level of Study: Postgraduate, Research 
Type: Prize

Value: $£ 400$

Frequency: Annual

Application Procedure: Essay and curriculum vitae.

Closing Date: June 1st

\section{Past \& Present Fellowships}

Subjects: Social history.

Purpose: To fund 1 year of postdoctoral research.

Eligibility: Applicants may be of any nationality and their $\mathrm{PhD}$ may have been awarded in any country. The fellowship may not be held in conjunction with any other award. Fellowships will begin on October 1st each year and it is a strict condition of these awards that a PhD thesis should have been submitted by that date.

Level of Study: Postdoctorate

Type: Fellowship

Value: Approx. UK£20,000

Length of Study: 1 year

Frequency: Dependent on funds available

Study Establishment: IHR

Country of Study: United Kingdom

No. of awards offered: 2 (may vary according to funds)

Application Procedure: Applicants must complete an application

form, available from the Fellowship Officer in early January.

Closing Date: March 31st

Funding: Private

Contributor: The Past and Present Society and IHR

No. of awards given last year: 2

No. of applicants last year: 200

Additional Information: Those who have previously held another postdoctoral research fellowship will not be eligible. The Fellowship cannot be held in conjunction with any other substantial maintenance grant.

\section{Royal History Society Fellowship}

Subjects: Medieval history, modern history and contemporary history. Purpose: To help candidates at an advanced stage of a PhD to complete their doctorates.

Eligibility: Open to nationals of any country.

Level of Study: Doctorate

Type: Fellowship

Value: Approx. UK£10,000

Length of Study: 1 year

Frequency: Dependent on funds available

Study Establishment: IHR

Country of Study: United Kingdom

No. of awards offered: 1

Application Procedure: Applicants must complete an application

form, available from the Fellowship Officer in early January.

Closing Date: March 4th

Funding: Private

Contributor: The Royal Historical Society

No. of awards given last year: 1

\section{Scouloudi Fellowships}

Subjects: Medieval history, modern history and contemporary history.

Purpose: To help candidates at an advanced stage of a PhD to complete their doctorates.

Eligibility: Only open to U.K. citizens or to candidates with a first degree from a U.K. university.

Level of Study: Doctorate

Type: Fellowship

Value: UK£10,000

Length of Study: 1 year

Frequency: Dependent on funds available

Study Establishment: IHR

Country of Study: United Kingdom

No. of awards offered: 5

Application Procedure: Applicants must complete an application

form, available from the Fellowship Officer in early January.

Closing Date: March 2nd

Funding: Private

Contributor: The Scouloudi Foundation

No. of awards given last year: 4

No. of applicants last year: 80

\section{Scouloudi Historical Awards}

Purpose: The purpose for these awards are as a subsidy towards the cost of publishing a scholarly book or article, or an issue of a learned journal in the field of history. To pay for research, and other expenses, to be incurred in the completion of advanced historical work, which the applicant intends subsequently to publish. This does not include expenses incurred in the preparation of a thesis for a higher degree. Eligibility: Awards are not available to those registered for undergraduate or postgraduate courses or degrees.

Level of Study: Doctorate, Postdoctorate, Research

Type: Award

Value: Up to $£ 1,000$

Frequency: Annual

Application Procedure: Applicants must submit an application form. Closing Date: March 11th

The Sir John Neale Prize in Tudor History

Subjects: 16th Century in England.

Purpose: The Neale Prize is awarded annually to a historian in the early stages of his/her career.

Eligibility: Candidates must either be registered for a higher degree at a British institution or have been registered for such a degree at a British institution within the last 3 years.

Level of Study: Postgraduate, Research

Type: Prize

Value: $£ 1,000$

Frequency: Annual

Application Procedure: An essay and an application form. Essays should be no more than 8,000 words including footnotes, on a theme related to Tudor history. Three double-spaced copies should be submitted.

Closing Date: April 15th

No. of applicants last year: 2

\section{INSTITUTE OF INTERNATIONAL EDUCATION}

\author{
809 United Nations Plaza, NY, New York, 10017 \\ United States of America \\ Email: whitaker@iie.org \\ Website: www.iie.org \\ Contact: Sabeen Altaf, Program Manager
}

Whitaker International Fellows and Scholars Program

Purpose: From 1975 until 2006, The Whitaker Foundation supported the development and enhancement of biomedical engineering (BME) in the US, contributing nearly $\$ 700,000,000$ to universities. When they closed, The Whitaker Foundation committed its remaining funds to the Institute of International Education to create the Whitaker International Fellows and Scholars Program, with the goal of enhancing international collaborative ties between the emerging leaders in the US BME community and their counterparts abroad.

Eligibility: Open to U.S.-based biomedical engineers who are graduating seniors, graduate students, postdocs or early-career professionals. Applicants should be either currently-enroled or no more than 3 years from their most recent degree.

Type: Fellowship

Value: Benefits include maintenance allowance, airfare, accident and sickness insurance, partial tuition reimbursement (Fellows only), and access to grantee events, as well as membership in an elite alumni resource network

Frequency: Annual

Closing Date: December 15th

Additional Information: For further information, please visit at www.iie.org/Programs/Whitaker-International-Fellows-and-ScholarsProgram.

\section{INSTITUTE OF IRISH STUDIES}

Queen's University Belfast, 53-67 University Road, Belfast, BT7 1NF, Northern Ireland

Tel: (44) 2890973386

Fax: (44) 2890973388

Email: irish.studies@qub.ac.uk

Website: www.qub.ac.uk/iis 
The Institute of Irish Studies at Queen's University was established in 1965 and was one of the first of its kind. It is one of the leading centres for research-based teaching in Irish studies and is an internationally renowned centre of interdisciplinary Irish scholarship attracting academics from all over the world.

\section{Institute of Irish Studies Research Fellowships}

Subjects: Any field of Irish studies.

Purpose: To promote research.

Eligibility: Candidates must hold at least a Second Class (Honours) degree, have research experience and a viable research proposal.

Level of Study: Postdoctorate

Type: Fellowship

Value: UK£28,000

Length of Study: 1 year

Frequency: Annual

Study Establishment: The Institute of Irish Studies, Queen's

University Belfast

Country of Study: Northern Ireland

No. of awards offered: Up to 3

Application Procedure: Applicants must see the website for details.

Awards are usually advertised in February to March.

Closing Date: Varies

Funding: Government

No. of awards given last year: 3

No. of applicants last year: 50

\section{Mary McNeill Scholarship in Irish Studies}

Subjects: Irish studies.

Eligibility: Open to well-qualified students enroled in the 1-year MA course in Irish studies at Queen's University. Applicants must be citizens of the USA or Canada and be enroled as overseas students in this course.

Level of Study: Postgraduate

Type: Scholarship

Value: UK£3,000

Length of Study: 1 year

Frequency: Dependent on funds available

Study Establishment: Queen's University Belfast

Country of Study: Northern Ireland

No. of awards offered: 1

Application Procedure: Application form can be downloaded from the website.

Closing Date: June 1st

No. of awards given last year: 1

\section{THE INSTITUTE OF MATERIALS, MINERALS AND MINING}

\author{
1 Carlton House Terrace, London, SW1Y 5DB, United Kingdom \\ Tel: (44) 01302320486$$
\text { Fax: (44) } 01302380900
$$ \\ Email: graham.woodrow@iom3.org \\ Website: www.iom3.org/index.htm \\ Contact: Dr M Urquhart, PA to Deputy Chief Executive
}

The Institute of Materials, Minerals and Mining (IOM3) was officially recognized by the UK's Privy Council on June 26th, created from the merger of The Institute of Materials (IOM) and The Institution of Mining and Metallurgy (IMM). The Institute intends to be the leading international professional body for the advancement of materials, minerals and mining to governments, industry, academia, the public, and the professionals.

\section{Bosworth Smith Trust Fund}

Subjects: Metal mining and non-ferrous extraction metallurgy or mineral dressing

Purpose: To assist research.

Eligibility: Open to applicants who possess a degree in a relevant subject.

Level of Study: Postgraduate

Value: Approx. UK£5,500 to cover working expenses, visits to mines and plants in connection with research and the purchase of apparatus Length of Study: 1 year
Frequency: Annual

Study Establishment: An approved university

Country of Study: United Kingdom

No. of awards offered: Varies

Application Procedure: Applicants must complete an application

form, available on request.

Closing Date: March 26th

\section{Edgar Pam Fellowship}

Subjects: All subjects within field of interest ranging from explorative geology to extractive metallurgy.

Eligibility: Open to young graduates resident in Australia, Canada, New Zealand, South Africa or the UK who wish to undertake advanced study or research in the UK.

Level of Study: Postgraduate

Type: Fellowship

Value: UK£2,000

Length of Study: 1 year

Frequency: Annual

Study Establishment: Approved universities

Country of Study: United Kingdom

No. of awards offered: 1

Application Procedure: Applicants must complete an application

form, available on request.

Closing Date: March 26th

\section{G Vernon Hobson Bequest}

Subjects: Mining geology.

Purpose: To advance the teaching and practice of geology as applied to mining.

Eligibility: Open to university staff throughout the UK.

Level of Study: Professional development

Value: Approx. UK£1,300 to cover travel, research or other objects in accordance with the terms of the bequest

Frequency: Annual

Country of Study: United Kingdom

No. of awards offered: More than 1

Application Procedure: Applicants must complete an application

form, available on request.

Closing Date: March 26th

\section{Mining Club Award}

Subjects: Mineral industry operations.

Purpose: To enable candidates to study in the UK or overseas, to present a paper at an international minerals industry conference or to assist the candidate in attending a full-time course of study related to the minerals industry outside the UK.

Eligibility: Open to British citizens aged $21-35$ years who are actively engaged in full or part-time postgraduate study or employment in the minerals industry.

Level of Study: Postgraduate, Professional development

Type: Award

Value: Approx. UK£1,500

Frequency: Annual

Country of Study: Any country

No. of awards offered: Varies

Application Procedure: Applicants must complete an application form, available on request.

Closing Date: March 26th

\section{Stanley Elmore Fellowship Fund}

Subjects: Extractive metallurgy and mineral processing.

Purpose: To provide funds for research that is related to metallurgy and mineral processing.

Eligibility: Preference will be given to Institute members, and for the Centenary Scholarship, Student Membership of the Institute is a requirement.

Level of Study: Postdoctorate, Doctorate

Type: Fellowship

Value: UK£14,000

Length of Study: 1 year

Frequency: Annual

No. of awards offered: 2

Closing Date: March 26th 
The Tom Seaman Travelling Scholarship

Subjects: Mining and/or related technologies.

Purpose: To assist the study for an aspect of engineering in the minerals industry.

Eligibility: Open to candidates who are training or have been trained for a career in mining.

Level of Study: Postgraduate, Professional development

Type: Scholarship

Value: Up to UK£5,500

Frequency: Annual

Application Procedure: A completed application form must be submitted.

Closing Date: March 26th

Additional Information: check the website for further details (www iom3.org/content/scholarships-bursaries).

For further information contact:

The Institute of Materials, Minerals and Mining

Tel: (0) 1302320486

Fax: (0) 1302380900

Contact: Dr GJM Woodrow, Deputy Chief Executive

\section{THE INSTITUTE OF SPORTS AND EXERCISE MEDICINE}

30 Devonshire Street, London, W1G 6PU, England Tel: (44) 02072885292

Email: d.patterson@ucl.ac.uk

Website: www.fsem.ac.uk

Contact: Miss Diana Meynell, Secretary

The Institute of Sports and Exercise Medicine is a postgraduate medical institute, which was established to develop research, teaching and treatment in sports medicine. It offers annual awards to medical practitioners and runs courses on different aspects of this specialist subject. In 2007 it became the research arm of the Faculty of Sport and Exercise Medicine (UK), with a remit to promote sport and exercise medicine research throughout the UK.

\section{Duke of Edinburgh Prize for Sports Medicine}

Subjects: Sports medicine in the community.

Purpose: To promote postgraduate work and signify standards of excellence.

Eligibility: Open to medical practitioners in the UK.

Level of Study: Postgraduate

Type: Prize

Value: Varies, but usually a substantial cash prize

Frequency: Annual

Country of Study: United Kingdom

No. of awards offered: Varies

Application Procedure: Applicants must write for an entry or

nomination form in the first instance.

Closing Date: See the website for details

Funding: Private

\section{Sir Robert Atkins Award}

Subjects: Sports medicine.

Purpose: To increase medical support and active involvement in the field and to recognize a doctor who has provided the most consistently valuable medical, clinical or preventive service to a national sporting organization or sport in general.

Eligibility: Open to medical practitioners in the UK.

Level of Study: Postgraduate

Type: Award

Value: Varies, but usually a substantial cash prize

Frequency: Annual

Country of Study: United Kingdom

No. of awards offered: 1

Application Procedure: Applicants must write for an entry or nomination form in the first instance.

Closing Date: Varies

Funding: Private

No. of awards given last year: 1

No. of applicants last year: 1

\section{INSTITUTE OF TRANSPERSONAL PSYCHOLOGY}

1069 E. Meadow Circle, Palo Alto, CA, 9430, United States of America Tel: (1) 6504934430 ext. 271 Fax: (1) 6504936835

Email: askinnerjones@itp.edu Website: www.itp.edu

Contact: Ms Ann Skinner-Jones

\section{Center for Sacred Feminine (CSF) Scholarship}

Subjects: Transpersonal psychology.

Purpose: To fund research to further the education and awareness of the Sacred Feminine, gender and feminist studies, and transpersonal psychology.

Eligibility: Awarded on a study's disciplinary emphasis on the Divine Feminine, gender studies, and Feminist studies that includes some element of the sacred in them, and/or the project's contribution to the field of transpersonal psychology and the Divine Feminine.

Level of Study: Doctorate, MBA

Type: Scholarship

Value: All scholarship awards are in the form of tuition reduction applied directly to ITP student accounts in equal installments in the Fall, Winter, and Spring

Frequency: Annual

Study Establishment: Institute of Transpersonal Psychology Country of Study: United States of America

No. of awards offered: 35

Application Procedure: Application form and other documents are available in the organization website.

Closing Date: April 25th

Contributor: The Center for the Divine Feminine (CDF)

\section{ITP Institute Scholarship}

Subjects: Transpersonal Psychology.

Purpose: The scholarship program is intended as a bridge to assist needy students in managing tuition increases.

Eligibility: Open to any student enroled in an Institute program. The awards for the scholarship are need based, with secondary consideration given to diversifying the student body and to students demonstrating high potential to advance the field of transpersonal psychology.

Level of Study: Research, MBA, Postdoctorate

Type: Scholarship

Value: $\$ 500-1,500$

Length of Study: 1 year

Frequency: Annual

Study Establishment: Institute of Transpersonal Psychology

Country of Study: United States of America

No. of awards offered: Varies

Application Procedure: Applicants must submit Institute Application Form, Cover Letter and Essay Student Aid Report, Global Scholarship Application Form and Residential Scholarship Application Form.

\section{President's Diversity Scholarship}

Subjects: Transpersonal Psychology.

Purpose: To support new incoming doctoral students of economic need and/or culturally diverse backgrounds.

Eligibility: New students who have been accepted into an Institute program and continuing students may qualify for the President's Scholarship. The awards are need-based with an emphasis on diversifying the student body. An award may be granted in additional years upon reapplication for the President's Scholarship by the March 1 st priority deadline. Awards are limited to students enroled full-time in an Institute Program.

Level of Study: Doctorate

Type: Scholarship

Value: 25 per cent tuition reduction

Length of Study: Up to 4 years

Frequency: Annual

Study Establishment: Institute of Transpersonal Psychology

Country of Study: United States of America

Application Procedure: Application form is available on website. Income verification statement (for non-U.S. citizens only), Student Aid Report (FAFSA (U.S. citizens only)), and a cover letter describing the 
student's qualifications for the scholarship (two pages maximum) should be attached with the application form.

Closing Date: June 1st

\section{Residential PhD African American Scholarship}

Subjects: Transpersonal Psychology.

Purpose: To assist with $\mathrm{PhD}$ tuition costs.

Eligibility: Applicants must be African American in full-time third year of the Residential PhD Program.

Level of Study: Doctorate

Type: Scholarship

Value: $\$ 1,000$ per quarter (maximum of $\$ 3,000$ per year) as tuition reduction and applied directly to student accounts in the Fall, Winter and Spring quarters

Frequency: Annual

Study Establishment: Institute of Transpersonal Psychology

Country of Study: United States of America

Application Procedure: To be considered for this scholarship, all applicants must complete both the application for this scholarship and the Free Application for Federal Student Financial Aid (FAFSA). Please contact the Financial Aid office at financial aid@itp.edu or 650493 4430, extn. 241) for more information on the FAFSA. Closing Date: June 1st

\section{INSTITUTE OF TURKISH STUDIES (ITS)}

Georgetown University, Intercultural Center 305R, Washington, DC, 20057 1033, United States of America

Tel: (1) 2026870295

Fax: (1) 2026873780

Email: dcc@turkishstudies.org

Website: www.turkishstudies.org

Contact: David C Cuthell, Director

The Institute of Turkish Studies (ITS) was founded and incorporated in the District of Columbia in 1982. It is the only non-profit, private educational foundation in the US that is exclusively dedicated to the support and development of Turkish Studies in U.S. higher education.

\section{Dissertation Writing Grants for Graduate Students}

Subjects: Social sciences and humanities.

Purpose: To fund advanced students who have finished the research stage of their dissertation.

Eligibility: Applicants must be graduate students in any field of the social sciences and/or humanities who are U.S. citizens or permanent residents at the time of the application, currently enroled in a $\mathrm{PhD}$ degree program in the US, and expecting to complete all $\mathrm{PhD}$ requirements except their dissertation by March.

Level of Study: Doctorate

Type: Grant

Value: US $\$ 5,000-15,000$

Length of Study: 1 academic year

Frequency: Annual

Application Procedure: A complete application must include the twopage grant application cover sheet completed in full, a project proposal (maximum six double-spaced pages), a budget statement, three letters of recommendation sent directly to ITS, an updated curriculum vitae and academic transcripts of all graduate work.

Closing Date: March 8th

Funding: Private

Additional Information: Decisions on applications will be announced in May. For further details check the website http://turkishstudies.org/ grants/grants_competition.shtml.

\section{Postdoctoral Summer Travel Grants}

Subjects: Ottoman and modern Turkish Studies.

Purpose: To provide partial support for travel and research to Turkey. Eligibility: Open to citizens or permanent residents of the US who currently live/work in the US. The candidates must have obtained a $\mathrm{PhD}$ in humanities or social sciences.

Level of Study: Research

Type: Grant

Value: Maximum award is round-trip airfare to Turkey

Length of Study: 4 weeks

Frequency: Annual
Country of Study: Turkey

Application Procedure: Applicants can download the application cover sheet from the website. The completed cover sheet along with a project proposal, budget, letters of recommendation and curriculum vitae must be submitted.

Closing Date: March 2nd

Additional Information: Application forms and supporting materials submitted by fax will not be accepted. Please see the website for further details http://turkishstudies.org/grants/grants competition. shtml.

\section{Summer Language Study Grants in Turkey for Graduate} Students

Subjects: Turkish language.

Purpose: To fund summer travel to Turkey for language study in preparation for graduate research.

Eligibility: Applicants must be graduate students in any field of the social sciences or humanities, currently enroled in a university in the USA. Open to citizens of the USA or permanent residents.

Level of Study: Graduate

Type: Grant

Value: US\$2,000-3,000

Length of Study: Minimum of 2 months

Frequency: Annual

Study Establishment: An established Ottoman or Turkish language training facility

Application Procedure: A complete application must include the twopage grant application cover sheet completed in full, a project proposal (maximum three double-spaced pages), a budget statement, three letters of recommendation sent directly to ITS, an updated curriculum vitae and academic transcripts of all graduate work.

Closing Date: March 8th

Funding: Private

Additional Information: Decisions on applications will be announced in May. For further details check the website.

\section{Summer Research Grants in Turkey for Graduate Students}

Subjects: Social sciences and humanities.

Purpose: To fund summer travel to carry out projects.

Eligibility: Applicants must be graduate students in any field of the social sciences or humanities in the USA, currently not engaged in dissertation writing. Applicants must be citizens of the USA or permanent residents.

Level of Study: Graduate, Postgraduate

Type: Grant

Value: US\$1,000-3,000

Length of Study: Varies, minimum of 2 months

Frequency: Annual

Application Procedure: A complete application must include the grant application cover sheet completed in full, a project proposal (maximum five double-spaced pages), a detailed budget stating the amount requested from ITS, three letters of recommendation sent directly to ITS, an updated curriculum vitae and academic transcripts of all graduates work.

Closing Date: March 11th

Funding: Private

Additional Information: Decisions on applications will be announced in May. For further details check the website http://turkishstudies.org/ grants/grants_competition.shtml.

\section{Turkish Studies Academic Conference Grant}

Subjects: Ottoman and modern Turkish studies.

Purpose: To support and encourage the development of research, scholarship and learning in the field of Turkish Studies in the US.

Eligibility: Open to postdoctoral scholars in the US who study aspects of the Republic of Turkey (post-1922). The applicants must be citizens or permanent residents of the US and affiliated with a university in the US.

Level of Study: Graduate, Doctorate, Postdoctorate

Type: Grant

Value: US\$10,000

Length of Study: 1 year

Frequency: Annual 
Application Procedure: Applicants can download the application cover sheet from the website. The completed cover sheet must be sent along with a project proposal, budget, letters of recommendation, curriculum vitae and academic transcripts.

Closing Date: Ongoing process (check the website)

Additional Information: Application forms and supporting materials submitted by fax will not be accepted. Please see the website for further details http://turkishstudies.org/grants/grants_competition.shtml.

\section{THE INSTITUTION OF CIVIL ENGINEERS}

1 Great George Street, Westminster, London, SW1P 3AA, England Tel: (44) 02076652193

Email: quest.awards@ice.org.uk

Website: www.ice.org.uk/quest

Contact: QUEST Coordinator

\section{QUEST Continuing Education Award}

Subjects: Civil engineering.

Purpose: This award provides financial support of up to $£ 2,500$ for ICE members who are working within the industry but would like to return to full or part time study to further their professional development.

Eligibility: Open to ICE graduate and professionally qualified members of at least 2 years standing. Applicants must also have at least 2 years industrial experience.

Level of Study: MBA, Postgraduate

Type: Award

Value: Up to UK£2,500

Frequency: Annual

Country of Study: United Kingdom

No. of awards offered: Approx. 10-15

Application Procedure: Applicants must complete an application form, arrange for a reference form to be completed by someone suitable and provide a one page employment history. Forms are available to download at www.ice.org.uk/questcea.

Closing Date: April 26th

\section{QUEST Travel Award}

Subjects: Civil engineering, environmental engineering, transportation and agricultural engineering.

Purpose: This award provides funding of up to $£ 1,500$ for ICE members and up to $£ 6,000$ for a group of ICE members to undertake an activity that furthers their professional development and which involves overseas travel.

Eligibility: Open to ICE graduate and professionally qualified members of at least 2 years standing.

Level of Study: Graduate, Postgraduate

Type: Travel award

Value: Up to $£ 6,000$ for groups

Frequency: Annual

Country of Study: Any country

No. of awards offered: Approx. 25

Application Procedure: Complete an application form and arrange for a reference form to be completed by someone suitable. Form can be downloaded from www.ice.org.uk/questtravel.

Closing Date: April 26th, September 28th

\section{THE INSTITUTION OF ENGINEERING AND TECHNOLOGY (IET)}

Michael Faraday House, Six Hills Way, Stevenage, Hertfordshire, SG1 2AY, England

$$
\text { Tel: (44) } 1438313311
$$

Fax: (44) 1438765526

Email: awards@theiet.org

Website: www.theiet.org/awards

Contact: J Tilley, Scholarships Coordinator

The IET is one of the world's largest engineering institutions with over 163,000 members in 127 countries. It is also the most interdisciplinary to reflect the increasingly diverse nature of engineering in the $21 \mathrm{st}$ century. Energy, transport, manufacturing, information and communications, and the built environment: the IET covers them all.
Hudswell International Research Scholarship

Subjects: Electrical, electronic, information technology, manufacturing engineering and related disciplines.

Purpose: To assist members of the IET with advanced research work, leading to the award of a doctorate, to be undertaken outside the applicant's home country.

Eligibility: Applicants should be members of the IET and must have commenced their studies prior to applying for this scholarship.

Level of Study: Postgraduate, Research, Doctorate

Type: Scholarship

Value: UK£5,000

Length of Study: 1 year

Frequency: Annual

Study Establishment: Internationally recognized universities or research establishments with a high reputation for research

Country of Study: Country of study must be different than the country of residence

No. of awards offered: 1

Application Procedure: Applicants should complete the online application form at www.theiet.org/postgradawards.

Closing Date: April

Funding: Trusts

\section{IET Postgraduate Scholarship for an Outstanding \\ Researcher}

Subjects: Engineering and Technology.

Purpose: To assist IET members with research studies.

Eligibility: Applicants should be members of the IET and must have commenced their studies prior to applying for this scholarship.

Level of Study: Research, Doctorate, Postgraduate

Type: Scholarship

Value: UK£10,000

Length of Study: 1 year

Frequency: Annual

Country of Study: Any country

No. of awards offered: 1

Application Procedure: Applicants should complete the online application form at www.theiet.org/postgradawards.

Closing Date: April

Funding: Trusts

\section{IET Postgraduate Scholarships}

Subjects: Engineering and Technology.

Purpose: To assist IET members with research studies.

Eligibility: Applicants should be members of the IET and must have commenced their studies prior to applying for this scholarship.

Level of Study: Doctorate, Postgraduate, Research

Type: Scholarship

Value: UK£2,500-£10,000

Length of Study: 1 year

Frequency: Annual

Study Establishment: University in the UK

Country of Study: United Kingdom

No. of awards offered: 5

Application Procedure: Applicants should complete the online application form at www.theiet.org/postgradawards.

Closing Date: April

Funding: Trusts

No. of awards given last year: 2

\section{IET Travel Awards}

Subjects: Engineering and Technology.

Purpose: To assist IET members undertaking international travel to attend conferences, work in industry or study tours.

Eligibility: Open to IET members

Level of Study: Unrestricted

Type: Travel grant

Value: UK£500

Length of Study: N/A

Frequency: Annual

Country of Study: Any country

No. of awards offered: Offer up to 12 awards per year

Application Procedure: Applicants should complete the online application form at www.theiet.org/travel-awards. 
Closing Date: Deadlines for applications can be found at http:// conferences.theiet.org/achievement/travel/index.cfm?origin $=/$ travelawards

\section{Funding: Trusts}

Additional Information: If a successful applicant does not undertake the visit, or submit a report within 1 month of the visit, they must return the funding to the IET. Awards are available throughout the year for IET members who present a paper/poster at conferences around the world, or participate in international research visits or projects.

\section{Leslie H Paddle Scholarship}

Subjects: Electronic and radio engineering.

Purpose: To assist IET members with research studies.

Eligibility: Applicants should be members of the IET and must have commenced their studies prior to applying for this scholarship.

Level of Study: Doctorate, Postgraduate, Research

Type: Scholarship

Value: UK£5,000

Length of Study: 1 year

Frequency: Annual

Study Establishment: University of Birmingham

Country of Study: United Kingdom

No. of awards offered: 1

Application Procedure: Applicants should complete the online

application form at www.theiet.org/postgradawards.

Closing Date: April

Funding: Trusts

No. of awards given last year: 1

Additional Information: Please check website for more information.

\section{INSTITUTION OF MECHANICAL ENGINEERS (IMECHE)}

1 Birdcage Walk, Westminster, London, SW1H 9JJ, England Tel: (44) 02072227899

Fax: (44) 02072224557

Email: enquiries@imeche.org

Website: www.imeche.org

Contact: The Prizes and Awards Officer

The Institution of Mechanical Engineers (IMechE) was founded in 1847 by engineers. They formed an institution to promote the exchange of ideas and encourage individuals or groups in creating inventions that would be crucial to the development of the world as a whole. Now, over 150 years later, IMechE is one of the largest engineering institutions in the world, with over 88,000 members in 120 countries.

\section{Donald Julius Groen Prize}

Subjects: Engineering.

Purpose: To award the author of outstanding papers or for outstanding achievements in the group's sphere of activity.

Eligibility: Open to authors of papers or those who have achievements of a sufficiently high standard to warrant the award of an IMechE prize. As a general rule, but with certain exceptions, grants are normally awarded only to members of the Institution.

Type: Prize

Value: UK£250

Frequency: Annual

No. of awards offered: 1

Application Procedure: Applicants must contact the Institution of Mechanical Engineers for details.

Funding: Private

Additional Information: Please see the website www.imeche.org/ knowledge/industries/tribology/prizes-and-awards/donald-juliusgroen-prize for details.

\section{James Clayton Overseas Conference Travel for Senior Engineers}

Subjects: Mechanical engineering

Purpose: To assist members of the Institution who have been invited to contribute in some way to a conference or who could be expected to make a significant contribution to the aims of a conference by their attendance.

Eligibility: Open to IMechE members over the age of 40 years.

Level of Study: Professional development

Type: Travel grant
Value: Up to UK£1,000

Country of Study: Any country

No. of awards offered: Varies

Application Procedure: Applicants must submit a completed

application form with 3 references.

Closing Date: Applications can be made throughout the year using the online application form

Funding: Private

Additional Information: A report is required 3 months after the conference. Please see the website for details.

\section{James Clayton Prize}

Subjects: Modern engineering science.

Purpose: To enable the recipient to pursue advanced postgraduate studies or programmes of research.

Eligibility: The award is open to IMechE members of all grades.

Level of Study: Postgraduate

Type: Grant

Value: Up to $£ 10,000$ plus certificate

Frequency: Annual

Study Establishment: An approved centre

Country of Study: United Kingdom

No. of awards offered: Approx. 10

Application Procedure: Nominations are considered by the Trustee Board Awards Committee in May and recommendations for awards are forwarded to the Trustee Board for approval in June. Download the Nomination form [from www.imeche.org/about-us/scholarshipsand-awards/recognition-awards/Prestige-Awards/James-Clayton-

Prize] and send with any supporting documentation to Karen Frost. Closing Date: Applications can be made throughout the year using the online application form

Funding: Private

Additional Information: Please email awards@imeche.org or call +44 (0) 1284717887 if you have any queries or experience problems downloading the form.

\section{For further information contact:}

ASK House, IMechE Prizes and Awards Department, Northgate Avenue, Bury St Edmunds, Suffolk, IP32 6BB, United Kingdom Contact: Karen Frost

\section{James Watt International Gold Medal}

Subjects: Mechanical engineering.

Purpose: To award an eminent engineer who has attained worldwide recognition in mechanical engineering.

Eligibility: The award is open to IMechE members of all grades as well as non members.

Type: Prize

Value: Gold medal

No. of awards offered: 1

Application Procedure: Applicants must write for details.

Closing Date: March 31st

Funding: Private

Additional Information: This award is the premier international award of the Institution. Please email awards@imeche.org or call + 44 (0) 1284717887 if you have any queries or experience problems downloading the documents.

\section{Postgraduate Masters Scholarships}

Subjects: Mechanical engineering.

Purpose: To assist graduates to undertake an IMechE accredited Masters degree for the purpose of obtaining the academic requirements for professional registration as a Chartered Engineer (CEng). Eligibility: Open to candidates who are currently resident in the UK, who will commence their IMechE accredited masters degree in the next academic session.

Level of Study: Postgraduate

Type: Scholarship

Value: Up to $£ 6,500$ (full-time), pro rata (part-time)

Length of Study: 1 year (full-time), 2 years (part-time)

Frequency: Annual

Country of Study: United Kingdom

Application Procedure: Please see the website www.imeche.org/

About-Us/scholarships-and-awards/postgraduate/masters-scholarships for complete details. 
Closing Date: August 1st

Funding: Private

Additional Information: It is intended that study should be on a 1-year full-time programme; however, if a suitable part-time 2 year programme is proposed, then the award may be divided equally in each year. For a part-time programme, renewal of the award after the first year is conditional on satisfactory progress being made.

\section{INTEL CORPORATION}

\author{
2200 Mission College Blvd, Santa Clara, CA, 95054 1549, \\ United States of America \\ Tel: (1) 4087658080 \\ Fax: (1) 4087653804 \\ Email: scholarships@intel.com \\ Website: www.intel.com
}

Intel Corporation is committed to maintaining and enhancing the quality of life in the communities where the company has a major presence.

\section{Intel Public Affairs Russia Grant}

Subjects: Science, mathematics, environmental students and technology education.

Purpose: To support further study programmes with educational and technological components in Russia.

Eligibility: Each request will be evaluated on the basis of the services offered and the programme's impact on the community and the potential for Intel employee involvement.

Type: Grant

Frequency: Annual

Country of Study: Russia

No. of awards offered: Varies

Application Procedure: Apply online or contact the office.

Funding: Corporation

Contributor: Intel Corporation

For further information contact:

30 Turgenev Street, Novgorod, Nizhny Novgorod, 603024, Russia Tel: (7) (831) 2969444

Email: paris@intel.com

Contact: Mr Evgeny Zakablukovsky, Russia Community and Regional Government Relations Manager

\section{INTENSIVE CARE SOCIETY (ICS)}

Churchill House, 35 Red Lion Square, London, WC1R 4SG, England Tel: (44) 02072804350

Fax: (44) 02072804369

Email: shaba@ics.ac.uk

Website: www.ics.ac.uk

Contact: Shaba Haque, Research Grant and Visiting Scholarship Enquiries \& Educational Events Team Leader

The Intensive Care Society (ICS) is a charitable organization promoting advances in the care of the critically ill. This is largely accomplished through educational means and promoting research activity.

\section{ICS Visiting Fellowship}

Subjects: Medicine.

Purpose: To provide the cost of travel to ICS members who wish to travel to an institution other than their own, either within the UK, or overseas. Eligibility: Open to all members of ICS.

Level of Study: Doctorate, Postdoctorate

Type: Fellowship

Value: Up to UK£5,000

Application Procedure: A written proposal of not more than 1,000 words should be submitted, outlining the proposed use of the grant, appropriate costs and the benefits accruing from the visit.

Closing Date: June 25th

\section{ICS Young Investigator Award (Research Grants)}

Subjects: Any aspect of intensive care medicine and care of the critically ill. Purpose: To promote research and intended to be pump-priming grants that will lead to further and more substantial support from other grant giving bodies.

Eligibility: Applicants must be ICS members. Please see the website for details.
Level of Study: Unrestricted

Type: Research grant

Value: $£ 15,000$

Frequency: Dependent on funds available

Country of Study: Any country

No. of awards offered: Varies

Application Procedure: Applications should be made to the Research Committee using the standard application form available from the ICS website. One Application to be sent electronically plus one original signed copy posted to the ICS offices. For any queries please contact jenny@ics.ac.uk.

Closing Date: March 1st

Funding: Private

Additional Information: Further information is available on the Society's website www.ics.ac.uk/foundation_home/grants/ new_investigator_award.

\section{INTER AMERICAN PRESS ASSOCIATION (IAPA)}

Jules Dubois Building, 1801 SW, 3rd Avenue, 8th Floor, Miami, FL, 33129, United States of America

Tel: (1) 3056342465

Fax: (1) 3056352272

Email: mestrada@sipiapa.org

Website: www.sipiapa.org

Contact: Martha Estrada, Assistant to the Executive Director

The Inter American Press Association (IAPA) was established in 1942 to defend and promote the right of the peoples of the America to be fully and freely informed through an independent press.

\section{IAPA Scholarships}

Subjects: Journalism in the print media.

Purpose: To help develop more rounded journalists through cultural exposure and study in a foreign country.

Eligibility: Open to all journalists or journalism school seniors or graduates between 21 and 35 years of age.

Level of Study: Postgraduate, Professional development

Type: Scholarship

Value: US $\$ 20,000$ and a one-time round-trip airfare for the year

Length of Study: 1 year

Frequency: Annual

Study Establishment: An American or Canadian university school of journalism approved by the Fund for Latin American and West Indian candidates, or an approved university or field work in a Latin American country for U.S. and Canadian candidates

Country of Study: Other

No. of awards offered: $4-6$

Application Procedure: Applicants must complete an application form, available from the Scholarships Director.

Closing Date: January 30th

Funding: Foundation, private

Contributor: Newspapers members; Foundations

Additional Information: Candidates should have good command of the language of the country they intend to visit. U.S. and Canadian Scholars must take a minimum of three university courses, participate in the Fund's Reporting Program, and undertake a major research project. The Association also gives IAPA awards of US $\$ 2,000$ and a scroll or plaque to Latin American and American journalists.

\section{INTERNATIONAL AGENCY FOR RESEARCH ON CANCER (IARC)}

\author{
150 Cours Albert Thomas, F-69372 Lyon Cedex 08, France \\ Tel: (33) 472738448 \\ Fax: (33) 472738080 \\ Email: fel@iarc.fr \\ Website: www.iarc.fr \\ Contact: Administrative Assistant IARC Fellowship Programme
}

The International Agency for Research on Cancer (IARC) is part of the World Health Organization. IARC's mission is to co-ordinate and conduct research into the causes of human cancer and the disease's mechanisms and to develop scientific strategies for cancer control. 
The Agency is involved in both epidemiological and laboratory research and disseminates scientific information through publications, meetings, courses and fellowships.

\section{IARC Postdoctoral Fellowships for Training in Cancer Research}

Subjects: Epidemiology (including genetic and molecular), biostatistics, bioinformatics, and areas related to mechanisms of carcinogenesis including molecular and cell biology, molecular genetics, epigenetics, and molecular pathology. There is an emphasis on interdisciplinary projects.

Purpose: To provide training in cancer research to junior scientists from any country. However applications from candidates from lowand medium-resource countries or from applicants from any parts of the world but with projects related to low- and medium-resource countries are encouraged.

Eligibility: Applicants are eligible from any country. Candidates should have finished their doctoral degree $(\mathrm{PhD})$ within 5 years of the closing date for application. The working languages at IARC are English and French. Candidates must be proficient in English at a level sufficient for scientific communication. Candidates are encouraged to contact the host group of their choice at IARC before application in order to establish a proposed programme of mutual interest. Candidates currently working as IARC-funded postdoctoral scientists, or candidates who have worked at the Agency as a postdoc for a period greater than 6 months cannot be considered.

Level of Study: Postdoctorate

Type: Fellowship

Value: Travel for the Fellow and for dependents if accompanying the Fellow for at least 8 months; an annual stipend of approx. $€ 33,000$, an annual family allowance of $€ 310$ for spouses and $€ 350$ for each child; and health insurance covered

Length of Study: 2 years, the 2nd year being subject to satisfactory appraisal

Frequency: Annual

Study Establishment: IARC in Lyon, France

Country of Study: France

No. of awards offered: Approx. 8-10

Application Procedure: Applicants must complete and submit an application form online.

Closing Date: November 30th

Contributor: IARC regular budget

No. of awards given last year: 11

No. of applicants last year: 98

Additional Information: It is anticipated that with widened experience gained from working at the Agency, the fellows will return to their home institute, able to make an increasing contribution to cancer research. As an international Agency with an interest in capacity building in LMICs, an important selection criterion is return home especially with regard to candidates from LMICs: additional points will therefore be granted to applications from LMIC candidates who are likely to return to their country of origin.

\section{INTERNATIONAL ANESTHESIA RESEARCH SOCIETY}

44 Montgomery Street, Suite 1605, San Francisco, CA, 94104, United States of America

Tel: (1) 4152966900

Fax: (1) 4152966901

Email: awards@iars.org

Website: www.iars.org

An International society committed to improving clinical care, education and research in anaesthesia, pain management and perioperative medicine.

\section{Frontiers in Anesthesia Research Award}

Subjects: Anesthesiology.

Purpose: To foster innovation and creativity by an individual researcher in the field of anesthesiology.

Eligibility: Please see the website for details regarding eligibility at www.iars.org/awards/frontiers. Must be a member of the International Anesthesia Research Society.

Level of Study: Unrestricted

Type: Research grant
Value: Maximum to $\$ 750,000$

Length of Study: 3 years

No. of awards offered: 1

Application Procedure: Applicants must submit a formal application to the IARS by the published deadline. Applicants must be a member of the IARS. Please see the website www.iars.org/awards/frontiers for complete application procedures.

Closing Date: January 30th

Funding: Corporation

Contributor: International Anesthesia Research Society

No. of applicants last year: $13-15$

Additional Information: If you have questions regarding the Frontiers Award, contact the IARS awards department at awards@iars.org.

\section{IARS Mentored Research Awards}

Subjects: Anesthesiology and related sciences.

Purpose: To support investigations that will further the understanding of clinical practice in anesthesiology and related sciences. The grants are intended to help create future leaders and prepare applicants to apply for independent research funding.

Eligibility: Applicant must be members of the International Anesthesia Research Society (IARS) and investigators who have yet to establish substantial funding.

Type: Research award

Value: Up to four research projects will be selected annually, with each award to receive a maximum of $\$ 150,000$, payable over 2 years Length of Study: 2 years

Frequency: Annual

Study Establishment: International Anesthesia Research Society

No. of awards offered: Up to 4

Application Procedure: Candidates should present a clear research plan, propose work that is pertinent to anesthesiology, and have both a senior mentor and an appointment in a successful Principal Investigator's group.

Closing Date: January 30th

No. of awards given last year: 4

Additional Information: Awards are granted at the sole discretion of the IARS. For more information please see the website www.iars.org/ awards/mentored.

\section{Teaching Recognition Award}

Subjects: Anaesthesiology.

Purpose: To recognize anesthesiology faculty who have demonstrated outstanding teaching skills and significant contributions to the academic community.

Eligibility: Must be a member of the International Anesthesia

Research Society.

Level of Study: Unrestricted

Type: Grant

Value: The Innovation in Education award includes a $\$ 1,000$ prize to the recipient and a $\$ 15,000$ educational grant to the recipient's institution to support the awardee's established and ongoing educational project. The Achievement in Education Award includes a \$1,000 personal prize to the recipient

Frequency: Annual

Study Establishment: International Anesthesia Research Society

No. of awards offered: 2

Application Procedure: Application must be submitted to the IARS by the published deadline. Applicant must be a member of the IARS. For more details please see the website www.iars.org/awards/teaching.

Closing Date: January 30th

No. of awards given last year: 2

Additional Information: Two separate awards, Innovation in Education and Achievement in Education, are granted annually.

Please see the website.

\section{INTERNATIONAL ASSOCIATION FOR THE STUDY OF INSURANCE ECONOMICS}

53 Route de Malagnou, $\mathrm{CH}-1208$ Geneva, Switzerland

Tel: (41) 227076600

Fax: (41) 227367536

Email: secretariat@genevaassociation.org

Website: www.genevaassociation.org 
The International Association for the Study of Insurance Economics was established in 1973 for the purpose of promoting economic research in the sector of risk and insurance.

\section{Ernst Meyer Prize}

Subjects: Risk and insurance economics.

Purpose: To recognize research work that makes a significant and original contribution.

Eligibility: Open to professors, researchers or students of economics. Level of Study: Doctorate, Unrestricted

Type: Prize

Value: Swiss Franc 5,000

Frequency: Annual

Country of Study: Any country

No. of awards offered: 1

Application Procedure: Applications should be addressed to The Geneva Association, 'Ernst Meyer Prize', General Secretariat, secretariat@genevaassociation.org.

Closing Date: January 31st

Funding: Private

No. of applicants last year: 7

Additional Information: Please see the website for details www. genevaassociation.org/prizes,-awards-and-grants.

\section{Research Grants}

Subjects: Risk management and insurance economics.

Purpose: To promote economic research.

Eligibility: Open to graduates involved in research for a thesis leading to a doctoral degree in economics.

Level of Study: Postgraduate

Type: Research grant

Value: Swiss Franc 10,000

Length of Study: 10 months

Frequency: Annual

Country of Study: Any country

No. of awards offered: 2

Application Procedure: Applications for research grants must be accompanied by a curriculum vitae, a research proposal and letters of recommendation from two professors of economics.

Closing Date: December 11th

Funding: Private

Additional Information: The Association reserves the right to support research on other subjects for which applications are submitted. The Association also grants authors of university theses already submitted, dealing in depth with a subject in the field of risk and insurance economics, a subsidy of up to Swiss Francs 3,000 towards printing costs. Please see the website for details www. genevaassociation.org/prizes,-awards-and-grants.

\section{Subsidies for Thesis}

Subjects: Topics of interest in risk management or insurance.

Purpose: To defray printing costs of university theses.

Eligibility: Open to authors of university theses already submitted.

Level of Study: Doctorate, Postdoctorate

Type: Grant

Value: Swiss Franc 3,000

Frequency: Annual

Application Procedure: Applications for subsidies for theses must be accompanied by a curriculum vitae, a description of the research undertaken and letters of recommendation from two professors of economics.

Closing Date: November 30th

Funding: Private

Additional Information: Please see the website for details www. genevaassociation.org/prizes,-awards-and-grants.

\section{INTERNATIONAL ASSOCIATION FOR THE STUDY OF OBESITY}

Charles Darwin House, 12 Roger Street, London, WCIN 2JU, United Kingdom

Tel: (44) 02076852580

Fax: (44) 02076852581

Email: enquiries@iaso.org

Website: www.iaso.org
The International Association for the Study of Obesity (IASO) aims to improve global health by promoting the understanding of obesity and weight-related diseases through scientific research and dialogue whilst encouraging the development of effective policies for their prevention and management. IASO is the leading global professional organization concerned with obesity, operating in over 50 countries around the world.

\section{The IASO New Investigator Award}

Subjects: Medicine and surgery.

Purpose: To promote interest in obesity research among investigators who are still in training.

Eligibility: Applicant must be a member of an IASO National Association. Level of Study: Doctorate, Postgraduate, Research

Type: Award/Grant

Value: Cash prize of US $\$ 500$ and a special award certificate

Length of Study: Variable

Study Establishment: Any

Country of Study: Any country

No. of awards offered: 1

Application Procedure: To apply for this award please download and complete the application form.

Closing Date: January 29th

Additional Information: For further information about the IASO New Investigator Award please write to awards@iaso.org.

For further information contact:

28 Portland Place, London, W1B 1LY, United Kingdom

Tel: (44) 2074679610

Fax: (44) 2076369258

Email: kate.baillie@iaso.org

Contact: Kate Baillie

\section{IASO Per Björntorp Travelling Fellowship Award}

Subjects: Medicine and surgery.

Purpose: To provide travel grants to enable young researchers to attend the International Congress of Obesity.

Eligibility: Applicants for this award must demonstrate their financial need for such support to attend the Congress. Applicants must be an IASO member. There is no age limit.

Level of Study: Doctorate, Postdoctorate, Postgraduate, Predoctorate, Research

Type: Studentships and bursaries

Value: Up to $\$ 2,000$ of return economy flights, congress Registration and hotel accommodation at the International Congress of Obesity

Study Establishment: Any

Country of Study: Any country

No. of awards offered: Varies

Application Procedure: Download the application form from website. Closing Date: See the website for details

Additional Information: For further information about the IASO

Travelling Fellowships Award please write to awards@iaso.org.

For further information contact:

28 Portland Place, London, W1B 1LY, United Kingdom

Tel: (44) 02074679610

Fax: (44) 02076369258

Email: kate.baillie@iaso.org

Contact: Kate Baillie

\section{INTERNATIONAL ASSOCIATION OF FIRE CHIEFS (IAFC) FOUNDATION}

4025, Fair Ridge Drive, Suite 300, Fairfax, VA, 22033, United States of America

Tel: (1) 7038964822

Email: sbaroncelli@iafc.org

Website: www.iafc.org

Contact: Diana Rothe-Smith, Association Manager

Each year, the International Association of Fire Chiefs (IAFC) Foundation co-ordinates a scholarship programme made possible through the generosity of corporations throughout the USA as well as donations from individuals and persons sponsoring a scholarship as a memorial to a friend or colleague. 


\section{IAFC Foundation Fire Explorer Scholarships}

Purpose: To assist Explorers in pursuing a career in the fire sciences or any related academic program.

Eligibility: Any fire service Explorer who is an active member of a state, county, provincial, municipal, community, industrial or federa fire department and who has demonstrated proficiency as such a member is eligible to apply. Please check the website for other criteria. Level of Study: Doctorate, Graduate, Postdoctorate, Professional development, Postgraduate, Predoctorate, MBA

Type: Scholarship

Value: US $\$ 500-5,000$

Frequency: Annual

Country of Study: Any country

Application Procedure: The applicant must submit a black-andglossy photo (such as a passport photo) for publicity purposes in the event of selection. Photo must be electronically submitted at 300 BP resolution to btaylor@lflmail.org. Application must be sent to William Taylor.

Closing Date: April 29th

Funding: Individuals, private, commercial

No. of awards given last year: 13

No. of applicants last year: 65

Additional Information: For more information about the IAFC

Foundation, please visit our website at www.iafcf.org.

For further information contact:

Learning for Life, S510, PO Box 152225, Irving, Texas, 750152225 United States of America

Contact: William Taylor

\section{INTERNATIONAL ASTRONOMICAL UNION (IAU)}

UAI Secretariat, 98 bis, boulevard Arago,

Paris, F-75014, France

Tel: (33) 143258358

Fax: (33) 143252616

Email: iau@iap.fr

Website: www.iau.org

Contact: Administrative Assistant

The mission of the International Astronomical Union (IAU), founded in 1919 , is to promote and safeguard the science of astronomy in all its aspects through international co-operation. The IAU, through its 12 scientific divisions and 40 commissions covering the full spectrum of astronomy, continues to play a key role in promoting and co-ordinating worldwide co-operation in astronomy.

\section{IAU Grants}

Subjects: Astronomy and astrophysics.

Purpose: To provide funds to qualified individuals to enable them to visit institutions abroad. It is intended that the visitors have ample time and opportunity to interact with the intellectual life of the host institution. It is a specific objective of the programme that astronomy in the home country is enriched after the applicant returns.

Eligibility: Open to faculty members, staff members, postdoctoral Fellows or graduate students at any recognized educational or research institution.

Level of Study: Graduate, Postdoctorate, Postgraduate, Research Value: One return economy fare between home and host institutions Length of Study: At least 3 months at a single host institution Country of Study: Any country

No. of awards offered: $12-15$ per year

Application Procedure: Applicants must submit an application including a curriculum vitae, a plan of scientific activity, letters of support from the home and host institutions, information on responsibility for subsistence at the host institution, and information on the lowest available fare. Applications should be submitted in time for the Officers of the Commission to consult by post.

Closing Date: There is no deadline

Contributor: Academy of Sciences

No. of awards given last year: 15

No. of applicants last year: 30

\section{INTERNATIONAL ATOMIC ENERGY} AGENCY (IAEA)

Vienna International Centre, PO Box 100, Vienna, 1400, Austria Tel: (43) 126000

Fax: (43) 126007

Email: crp.research@iaea.org

Website: http://cra.iaea.org

Contact: Section Head - NACA

The IAEA is the world's center of cooperation in the nuclear field. It was set up as the world's 'Atoms for Peace' in 1957 within the United Nations family. The agency works with its Member States and multiple partners worldwide to promote safe, secure and peaceful nuclear technologies.

\section{Research Contracts (IAEA)}

Subjects: Any scientific or technical field related to the peaceful uses of atomic energy and the use of radio-isotopes in agriculture, industries, medicine, research, etc.

Purpose: To encourage and assist research on the development and practical application of atomic energy for peaceful purposes throughout the world.

Eligibility: Institutions with research projects developed in line with the overall goals of the IAEA. Priority is normally given to proposals received from institutions in developing countries (headed by young and female researchers).

Level of Study: Research

Type: Research

Value: Approx. $€ 6,000$ per year per contract

Length of Study: 1 year (extension possible up to 3 years)

Frequency: Annual

Application Procedure: Application forms are available on request or can be downloaded from http://cra.iaea.org. Research proposals could be submitted either based on a proposal made by the IAEA or a proposal developed by the research institute itself.

Closing Date: Proposals accepted throughout the year - See on http.//cra/iaca.org

No. of awards given last year: 945

No. of applicants last year: 1,330

Additional Information: Research Proposals will be considered which involve nuclear technologies or applications and relate to the IAEA programme. Only available to IAEA member states.

\section{INTERNATIONAL CENTER FOR JOURNALISTS (ICFJ)}

1616 H Street NW, Third floor, Washington, DC 20006, United States of America

Tel: (1) 2027373700

Fax: (1) 2027370530

Email: editor@icfj.org

Website: www.icfj.org

The International Center for Journalists (ICFJ), a non-profit, professional organization, promotes quality journalism worldwide in the belief that independent, vigorous media are crucial in improving the human condition

\section{Arthur F. Burns Fellowship Program}

Subjects: Media and journalism.

Purpose: The program offers young print and broadcast journalists from each country the opportunity to share professional expertise with their colleagues across the Atlantic while working as 'foreign correspondents' for their hometown news organizations.

Eligibility: Open to U.S. and German journalists between the age of 21-37, who are employed by a newspaper, news magazine, broadcast station, news agency or who work freelance and/or online. Applicants must have demonstrated journalistic talent and a strong interest in U.S.-European affairs. German language proficiency is not required, but it is encouraged.

Level of Study: Professional development, Unrestricted

Value: $\$ 4,000$ stipend (with $\$ 1,200$ for travel expenses)

Length of Study: 2 months (August-September)

Frequency: Annual 
No. of awards offered: 10 from each country

Application Procedure: Please refer to the website at

www.icfj.org/burns.

Closing Date: March 1st

Funding: Corporation, foundation, individuals, private

Additional Information: Countries of study are Germany and USA.

\section{Knight International Journalism Fellowships}

Subjects: Journalism and media.

Purpose: To improve the free flow of news and information in the public interest around the world.

Level of Study: Postdoctorate

Type: Fellowship

Value: Work with media partners in developing countries to launch projects to improve the free flow of news and information in the public interest

Length of Study: 1 year

Frequency: Annual

Study Establishment: International Center for Journalists

No. of awards offered: Approx. 22

Application Procedure: Apply online at www.icfj.org/our-work/knight. Closing Date: December 1st

Funding: Foundation

Contributor: John S. and James L. Knight Foundation

Additional Information: Contact the Center by fax or mail for detailed application and program guidelines. These aren't really awards. They are essentially contracted assignments.

\section{The McGee Journalism Fellowship in Southern Africa}

Subjects: Journalism and technical, management and business aspects of the media.

Purpose: To help journalists improve the skills and standards they need to carry out their work.

Eligibility: Open candidates of outstanding personal and professional achievement in journalism, with experience of teaching overseas, a readiness to work under difficult conditions and an interest in Southern Africa.

Level of Study: Postdoctorate

Type: Fellowship

Value: The fellowship covers all travel, housing, health insurance, living expenses and an honorarium of US $\$ 100$ per day

Frequency: Annual

Study Establishment: An approved South African University

Country of Study: South Africa

No. of awards offered: 1

Application Procedure: Submit a completed application form, an essay of 500 words or less and three letters of personal or professional recommendation.

Closing Date: April 16th

Funding: Foundation

Contributor: McGee Foundation

\section{INTERNATIONAL CENTRE FOR EDUCATION IN ISLAMIC FINANCE (INCEIF)}

Lorong Universiti A, Universiti Malaya, 59100 Kuala Lumpur, Wilayah Persekutuan Kuala Lumpur, Malaysia Tel: +60 376514000

Email: syarina@inceif.org Contact: Noorsyarina Mohd Sapiai

\section{Khazanah - INCEIF Scholarship}

Subjects: Islamic Finance.

Eligibility: Information available on website: www.inceif.org/ khazanah-inceif-scholarship-programme/.

Level of Study: Doctorate, Postgraduate

Value: All applicable tuition fees and monthly allowances for the duration of the course

Study Establishment: INCEIF

Country of Study: Malaysia

Application Procedure: Kindly contact Ms Noorsyarina Mohd Sapiai at syarina@inceif.org for further assistance.

Closing Date: March 16th
Additional Information: Eligible to nationals of Malaysia. All communications will be done via email. Therefore please ensure the email address given is correct and active.

\section{INTERNATIONAL CENTRE FOR GENETIC ENGINEERING AND BIOTECHNOLOGY (ICGEB)}

\author{
AREA Science Park, Padriciano 99, Trieste, 34149, Italy \\ Tel: (39) 04037571 \\ Fax: (39) 040226555 \\ Email: fellowships@icgeb.org \\ Website: www.icgeb.org \\ Contact: Human Resources Unit
}

The International Centre for Genetic Engineering and Biotechnology (ICGEB) is an organization devoted to advanced research and training in molecular biology and biotechnology, with special regard to the needs of the developing world. The component host countries are Italy, India and South Africa. The full member states of ICGEB are Afghanistan, Algeria, Argentina, Bangladesh, Bhutan, Bosnia and Herzegovina, Brazil, Bulgaria, Burundi, Cameroon, Chile, China, Colombia, Costa Rica, Côte d'Ivoire, Croatia, Cuba, Ecuador, Egypt, Eritrea, FYR Macedonia, Hungary, Iran, Iraq, Jordan, Kenya, Kuwait Kyrgyzstan, Liberia, Libya, Malaysia, Mauritius, Mexico, Montenegro Morocco, Nigeria, Pakistan, Panama, Peru, Poland, Qatar, Romania, Russia, Saudi Arabia, Senegal, Serbia, Slovakia, Slovenia, Sri Lanka, Sudan, Syria, Tanzania, Trinidad and Tobago, Tunisia, Turkey, United Arab Emirates, Uruguay, Venezuela, and Vietnam.

The Arturo Falaschi ICGEB Flexible Fellowships

Subjects: Molecular medicine, tumour virology, yeast molecular genetics, bacteriology, protein structure and bioinformatics, molecular pathology, molecular immunology, biosafety, biotechnology development, human molecular genetics, molecular virology, mouse molecular genetics, neurobiology, protein networks, mammalian biology, malaria, recombinant gene products, immunology, structural and computational biology, virology, cancer genomics, plant molecular biology, plant transformation, insect resistance, synthetic biology and biofuels, molecular haematology, Cancer genomics, cancer molecular and cell biology, cellular immunology, cytokines, and disease.

Purpose: To provide short-term training in genetic engineering and biotechnology for scientists from the member states of ICGEB, and to promote academic and industrial research in an international context. Eligibility: Open to promising pre- and postdoctoral students, who are nationals of one of the member states of ICGEB.

Level of Study: Postdoctorate, Predoctorate

Type: Fellowship

Value: An allowance to cover travel costs as well as boarding and lodging

Length of Study: 6-12 years

Frequency: Annual

Study Establishment: ICGEB laboratories in Trieste, Italy; New Delhi, India; Cape Town, South Africa; ICGEB Outstation at

Monterotondo (Rome), Italy

No. of awards offered: Varies

Application Procedure: Applicants must submit a complete application through the ICGEB Liaison Officer of the applicant's country of origin. Application forms can be found on the website.

Closing Date: Applications are accepted at any time

Additional Information: Endorsed applications must arrive at ICGEB Trieste on or before April 30th, each year. For further information please refer to the website www.icgeb.org/fellowships.html.

The Arturo Falaschi ICGEB Postdoctoral Fellowships

Subjects: Mammalian biology: virology, immunology, malaria, recombinant gene products, structural and computational biology. Plant biology: plant molecular biology, plant transformation, insect resistance, synthetic biology and biofuels; Bacteriology, Biosafety, Biotechnology Development, Cellular Immunology, Human Molecular Genetics, Molecular Immunology, Molecular Medicine, Molecular Pathology, Molecular Virology, Mouse Molecular Genetics, Neurobiology, Protein Networks, Protein Structure and Bioinformatics, Tumour Virology, Yeast Molecular Genetics, Cancer Genomics, Cancer Molecular and Cell Biology, Cellular Immunology, Cytokines and Disease; Molecular Hematology. 
Purpose: To provide long-term training in genetic engineering and biotechnology for scientists from the member states and to promote state-of-the art academic and industrial research training in an international context and for the scientific development of the Fellow's home country.

Eligibility: Open to promising postdoctoral or established research students under the age of 35, who are nationals of one of the ICGEB member states to carry out their study in India, Italy or South Africa. Level of Study: Postdoctorate

Type: Fellowship

Value: Monthly stipend: Trieste (Italy): €2,000; New Delhi (India): US\$1,590; Cape Town (South Africa): Rand 15,000; and travel costs and medical insurance

Length of Study: 2 years with the possibility of a 1-year extension Frequency: Annual

Study Establishment: ICGEB laboratories in Trieste, Italy; New Delhi, India; Cape Town, South Africa; and Outstation at Monterotondo (Rome), Italy

No. of awards offered: Varies

Application Procedure: Applicants must submit the complete application through the respective National Liaison Officer in their country of origin.

Closing Date: March 31st and September 30th

Additional Information: For further information please refer to the website.

\section{The Arturo Falaschi ICGEB Predoctoral Fellowships ICGEB Cape Town International PhD Programme}

Subjects: Cancer genomics, cancer molecular and cell biology, cellular immunology, cytokines and disease.

Purpose: To offer postgraduate training with the aim of obtaining a $\mathrm{PhD}$ degree in the field of life sciences at the University of Cape Town, South Africa, in collaboration with the ICGEB.

Eligibility: Applicant must be below the age of 32 years and nationals of one of the ICGEB member states and must have a BSc (honours) degree. Level of Study: Predoctorate

Type: Fellowship

Value: Stipends to cover the cost of normal living expenses (annually) for one person at the location of the individual host institute; fellowships are renewable for the following years provided that the PhD Programme requirements are fulfilled, travel cost to and from the host country and medical health insurance cover the PhD Programme requirements are fulfilled

Length of Study: Up to 3 years

Frequency: Annual

Study Establishment: ICGEB laboratories in Cape Town

Country of Study: South Africa

No. of awards offered: Varies

Application Procedure: Applicants must refer to the website. Closing Date: March 31st

Additional Information: For more information on this programme please refer to the website.

\section{The Arturo Falaschi ICGEB Predoctoral Fellowships} ICGEB New Delhi International PhD Programme

Subjects: Mammalian biology: virology, immunology, malaria, recombinant gene products, structural and computational biology. Plant biology: plant molecular biology, plant transformation, insect resistance, synthetic biology and biofuels.

Purpose: To offer postgraduate training with the aim of obtaining a $\mathrm{PhD}$ degree in the field of life sciences at the Jawaharlal Nehru University in New Delhi, in collaboration with the ICGEB.

Eligibility: Open to promising young students in possession of an MSc degree from a recognized university, who are nationals of one of the ICGEB member states. Indian nationals are not eligible to apply. Level of Study: Postgraduate, Predoctorate

Type: Fellowship

Value: The stipends are provided to cover the costs of normal living costs for the holder at the location studying for the programme. Travel fares to and fro from the host country, medical health insurance coverage, accommodation services are also provided

Length of Study: Up to 3 years

Frequency: Annual

Study Establishment: ICGEB laboratories in New Delhi

Country of Study: India
No. of awards offered: Varies

Application Procedure: Applicants must refer to the website. Closing Date: March 31st

Additional Information: For more information on this programme please refer to the website.

\section{The Arturo Falaschi ICGEB Predoctoral Fellowships ICGEB Trieste International PhD Programme}

Subjects: Molecular medicine, tumour virology, bacteriology, protein structure and bioinformatics, molecular pathology, molecular immunology, human molecular genetics, molecular virology, mouse molecular genetics, neurobiology, protein networks, yeast molecular genetics, cellular immunology, and molecular hematology.

Purpose: To enable promising young students to attend and complete the PhD programme at ICGEB Trieste in Italy. The programme is validated by the Open University, UK, and the University of Nova Gorica, Slovenia.

Eligibility: Open to students having a BSc (Hons) university degree under the age of 32 from any member state of the ICGEB.

Level of Study: Predoctorate

Type: Fellowship

Value: Stipends to cover the cost of normal living expenses (annually) for one person at the location of the individual host institute; fellowships are renewable for the following years provided that the PhD Programme requirements are fulfilled. Cost to cover travel to and from the host country and medical health insurance cover

Length of Study: Up to 3 years

Frequency: Annual

Study Establishment: ICGEB laboratories in Trieste and Monterotondo (Rome)

Country of Study: Italy

No. of awards offered: Varies

Application Procedure: Applicants must refer to the website. Closing Date: March 31st

Additional Information: For more information on this programme please refer to the website.

\section{INTERNATIONAL CENTRE FOR PHYSICAL LAND RESOURCES}

\author{
University of Ghent, Krijgslaan 281/S8, B-9000 Ghent, Belgium \\ Tel: (32) 92644638 \\ Fax: (32) 92644991 \\ Email: plrprog.adm@ugent.be \\ Website: www.plr.ugent.be \\ Contact: Professor E Van Ranst
}

The International Centre for Physical Land Resources has a longstanding tradition in academic formation and training in physical land resources, including soil science, soil survey, land evaluation, agricultural applications and eremology, e.g. dryland and desertification. Since 1997, the scope of the courses has been widened with courses on the non-agricultural use and application of physical land resources. Students can major in either soil science or land resources engineering. Teaching is provided by lecturers of the University of Ghent and of the Free University of Brussels (VUB).

Master Studies in Physical Land Resources Scholarship Subjects: Fundamental soil science, soil genesis, prospection and classification, non-agricultural use and applications of land and soils, geotechnical engineering, soil mechanics and hydrogeology, management of physical and land resources, agricultural applications, soil fertility, soil erosion and conservation or land evaluation.

Purpose: To provide MSc training opportunities to nationals from developing countries.

Eligibility: Open to nationals of the developing world or non-

European Union members.

Level of Study: Master

Type: Scholarship

Value: $€ 1,200$ per month

Length of Study: 2 years

Frequency: Annual

Study Establishment: Ghent University

Country of Study: Belgium

No. of awards offered: Approx. 2 
Application Procedure: Applicants must complete an application form and submit this with certified diplomas and transcripts to the Programme Secretariat to obtain academic admission.

Closing Date: March 1st (check the website)

Funding: Government, private

No. of awards given last year: 1

No. of applicants last year: 45

Additional Information: For any enquiry email to

PLRprog.adm@UGent.be and see the website for more details.

\section{INTERNATIONAL COLLEGE OF SURGEONS}

1516 North Lakeshore Drive, Chicago, IL, 60610, United States of America

Tel: (1) 3126423555

Fax: (1) 3127871624

Email: max@icsglobal.org

Website: www.icsglobal.org

Contact: International Executive Director

\section{Postgraduate Scholarships}

Subjects: Surgery.

Purpose: To bring surgeons and surgical specialists of all nations, races, and creeds together, to promote surgical excellence for the benefit of all of mankind and to foster fellowship worldwide. Eligibility: Applicants must have graduated from an accredited medical school, completed their residency and be licensed to practice surgery in their home country (documentation of licensure must be provided). You do not have to be a Fellow of ICS to be eligible. Level of Study: Postgraduate

Value: See the college website for details

Length of Study: Committee will consider the amount of time allocated to the program

Study Establishment: Established treatment, research facilities or educational institutions

Application Procedure: All grant requests must be accompanied by a current curriculum vitae, which includes such information as education, post graduate training, current hospital affiliations, surgical specialty, other research activity, publications and presentations, etc. Completed applications should be sent to the Executive Director.

Closing Date: Check the website

Contributor: Voluntary contributions, which are made to the College by Fellows and other interested persons

Additional Information: Please see the website for further details www.icsglobal.org/about/scholarship_grants/au_sg_apply.asp.

\section{THE INTERNATIONAL DAIRY- DELI-BAKERY ASSOCIATION}

IDDBA, 636 Science Drive, PO Box 5528, Madison, WI, 53711 1073, United States of America Tel: (1) 6083105000 Fax: (1) 6082386330

Email: iddba@iddba.org Website: www.iddba.org

Our mission is to expand our leadership role in promoting the growth and development of daily, deli, and bakery sales in the food industry. Our vision is to be the essential resource for relevant information and services that add value across all food channels for the dairy, deli and bakery categories.

\section{IDDBA Graduate Scholarships}

Subjects: Culinary arts, baking/party arts, food service, business and marketing.

Purpose: To support employees of IDDBA-member companies.

Eligibility: Applicants must be a current full- or part-time employee of an IDDBA-member company with an academic background in a foodrelated field and have a 2.5 grade-point average on a 4.0 scale, or equivalent.

Level of Study: Postgraduate

Type: Scholarship

Value: US $\$ 250$ to $\$ 1,000$
Length of Study: 1 year

Frequency: Annual

Country of Study: United States of America

No. of awards offered: Varies

Application Procedure: Contact the Education Information Specialist.

Closing Date: January 1st, April 1st, July 1st, October 1st

Funding: Foundation

Contributor: IDDBA

Additional Information: For additional information or enquiries contact organization and email at scholarships@iddba.org. Please see the website for further details www.iddba.org/scholarships.aspx.

For further information contact:

Email: kpeckham@iddba.org

\section{INTERNATIONAL DEVELOPMENT RESEARCH CENTRE (IDRC)}

PO Box 8500, 150 Kent Street, Ottawa, ON, K1P 0B2, Canada Tel: (1) 6132366163

Fax: (1) 6132364026

Email: cta@idrc.ca

Website: www.idrc.ca

The International Development Research Centre (IDRC) is a Canadian crown corporation created by the Canadian government to help communities in the developing world find solutions to social, economic and environmental problems through research.

\section{The Bentley Cropping Systems Fellowship}

Subjects: Agriculture, forestry or biology.

Purpose: To provide assistance to Canadian and a developing country's graduate students with a university degree in agriculture, forestry or biology, who wish to undertake post-graduate, applied onfarm research with co-operating farmers in a developing country. Eligibility: Applicants must be Canadian citizens, permanent residents of Canada or citizens of a developing country who are enroled full-time in a graduate program (Master's, doctoral, postdoctoral) at a recognized university in Canada or in a developing country for the duration of the award period.

Level of Study: Unrestricted, Doctorate, Graduate, Postdoctorate, Postgraduate

Type: Fellowship

Value: Up to Canadian $\$ 30,000$. If there is strong evidence of significant potential benefits, the award may be extended upon re-application

Length of Study: 1.5-2 years

Frequency: Every 2 years

Study Establishment: Universities

No. of awards offered: 1-2

Application Procedure: Applicants must complete and submit an application form with various supporting documents. For further information see the IDRC website.

Closing Date: October 1st

Funding: Private

No. of applicants last year: Varies

Additional Information: Please see the website for details www.idrc ca/EN/Funding/WhoCanApply/Pages/Bentley-Cropping-SystemsFellowship.aspx.

For further information contact:

The Bentley Fellowship, Fellowships and Awards, International Development Research Centre (IDRC), PO Box 8500, Ottawa, ON, K1G 3H9, Canada

\section{Canadian Window on International Development}

Subjects: Agriculture and environment.

Purpose: To support field research in Canada and one or more developing countries.

Eligibility: Open to Canadian citizens, permanent residents of Canada and a developing country's nationals. Applicants must be registered at a Canadian university. See website for more details. Level of Study: Doctorate, Graduate, Postgraduate, Master's Value: Up to Canadian $\$ 20,000$ 
Length of Study: 3 months to 1 year

Frequency: Annual

Study Establishment: Universities

Country of Study: Canada

No. of awards offered: $2-3$

Application Procedure: Applicants must complete an application form. Please refer to the website www.idrc.ca/awards for details.

Closing Date: April 1st

Funding: Government

No. of awards given last year: 1

No. of applicants last year: Varies

\section{Community Forestry: Trees and People-John G. Bene \\ Fellowship}

Subjects: Forestry or agroforestry with social sciences.

Purpose: To assist Canadian graduate students in undertaking

research on the relationship between forest resources and the social,

economic, cultural and environmental welfare of people in developing countries.

Eligibility: Open to Canadian citizens and permanent residents who are registered at a Canadian university at the Master's or doctoral

level. Applicants must have an academic background that combines

forestry or agroforestry with social sciences.

Level of Study: Doctorate, Graduate, Postgraduate

Type: Fellowship

Value: Canadian $\$ 15,000$

Length of Study: 3 months to 1 year

Frequency: Annual

Study Establishment: Universities

Country of Study: Canada

No. of awards offered: 1

Application Procedure: Applicants must submit a research proposal and various supporting documents as part of their application. See the website for details.

Closing Date: April 1st

Funding: Private

Contributor: Endowment

No. of awards given last year: 1

No. of applicants last year: Varies

Additional Information: Please see the website for more details www.idrc.ca/EN/Funding/WhoCanApply/Pages/John-G-BeneFellowship.aspx.

\section{ECOPOLIS Graduate Research and Design Awards}

Subjects: Environmental issues borne by the poor.

Purpose: To promote research and design projects that help lighten the environmental problems borne by the urban poor.

Eligibility: Open to Canadian citizens or permanent residents of Canada as well as citizens of developing countries.

Level of Study: Doctorate, Graduate, Master's

Type: Award

Value: Research awards - maximum of Canadian $\$ 20,000$ covers justifiable field work expenses. Design awards - maximum of Canadian $\$ 40,000$

Frequency: Annual

No. of awards offered: Up to 10 in total. Up to 5 - Research awards,

Up to 5 - Design awards

Application Procedure: Visit the IDRC website for further information.

Closing Date: May 15th

Funding: Government

No. of awards given last year: 9

No. of applicants last year: Varies

\section{IDRC Doctoral Research Awards}

Subjects: Agriculture and environment

Purpose: To promote the growth of Canadian capacity in research on sustainable and equitable development from an international perspective.

Eligibility: Open to Canadian citizens and permanent residents and a developing country's nationals. Applicants must be enroled in a Canadian university, have a research proposal that has been approved by the thesis supervisor and be affiliated with an institution or organization in the region where the research will take place. Level of Study: Doctorate
Type: Award

Value: Up to Canadian $\$ 20,000$ each

Length of Study: 3 months to 1 year

Study Establishment: Universities. Normally, such research is conducted in Latin America, Africa, the Middle East or Asia

Country of Study: Canada

No. of awards offered: Varies (20-25 per year)

Application Procedure: Applicants must complete and submit an application form with a research proposal and various supporting documents. Information on required documents is available on the IDRC website. You may only apply for the competition that is posted on the Competitions page.

Closing Date: May 20th

Funding: Government

Contributor: The Canadian government

No. of awards given last year: 18 to 20

No. of applicants last year: Varies

Additional Information: Please see the website for further details www.idrc.ca/EN/Funding/WhoCanApply/Pages/Doctoral-ResearchAwards.aspx.

\section{IDRC Evaluation Research Awards}

Subjects: Theory and practice of evaluation.

Purpose: To promote the growth of Canadian and developing country capacity in evaluation and to better the theory and practice of evaluation.

Eligibility: Applicants must be Canadian citizens, permanent residents of Canada or citizens of a developing country and be enroled at the Master's or Doctoral level in a Canadian university or a recognized university in a developing country.

Level of Study: Doctorate, Graduate, Master's

Type: Award

Value: Salary for one year: Canadian $\$ 39,797-46,070$

Length of Study: 3-12 months

Frequency: Annual

No. of awards offered: 2

Application Procedure: Applicants must submit a research proposal and various supporting documents as part of their application. Information on required documents and the application form are available on the IDRC website.

Closing Date: August 6th

Funding: Government

No. of applicants last year: Varies

Additional Information: The evaluation research awards will not be granted for Evaluation research that only judges the effectiveness of particular development interventions (projects, programs, activities, etc.)

\section{IDRC Research Awards}

Subjects: Social and Economic Policy, Agriculture and Environment, Information and Communication Technologies for Development, Innovation, Policy and Science, Research for Health Equity. Purpose: The program is aimed at candidates who, through demonstrated achievements in academic studies, work, or research, have shown interest in creating and using knowledge from an international perspective.

Eligibility: Applicants must be Canadian citizens, permanent residents of Canada or citizens of a developing country and be enroled in the postgraduate studies or have obtained a postgraduate degree.

Level of Study: Graduate, Doctorate, Master's

Type: Award

Value: Salary in a range from Canadian $\$ 36,754$ to Canadian $\$ 42,548$ per year. Some travel and research expenses will also be supported up to a maximum of Canadian $\$ 10,000$. The salary range and benefits for interns located in the regional offices may vary according to regional conditions

Length of Study: 1 year

Frequency: Annual

\section{No. of awards offered: Varies}

Application Procedure: Applicants must submit a research proposa and various supporting documents as part of their application. Note that all applications must be sent online.

Closing Date: September 12th

Funding: Government

No. of awards given last year: 14

No. of applicants last year: 120 
Additional Information: Candidates must conduct their research in areas corresponding to IRRC's research priorities_Please see the website for further details www.idrc.ca/EN/Funding/WhoCanApply/ Pages/Internships@IDRC.aspy

For further information contact:

Tel: 6136962098

Fax: 6132364026

\section{THE INTERNATIONAL FEDERATION OF UNIVERSITY WOMEN (IFUW)}

IFUW Headquarters, 10 rue de Lac, Geneva, $\mathrm{CH}-1207$, Switzerland Tel: (41) 227312380

Fax: (41) 227380440

Email: info@ifuw.org

Website: www.ifuw.org

The International Federation of University Women (IFUW) is a nonprofit, non-governmental organization comprising graduate women working locally, nationally and internationally to advocate the improvement of the status of women and girls at the international level, by promoting lifelong education and enabling graduate women to use their expertise to effect change.

\section{British Federation Crosby Hall Fellowship}

Subjects: All subjects.

Purpose: To encourage advanced scholarship and original research relevant to IFUW's mission.

Eligibility: Open to female applicants who are either members of one of IFUW's national federations or associations or, in the case of female graduates living in countries where there is not yet a national affiliate, independent members of IFUW, or other applicants who pay a filing fee. Applicants should have completed at least the first year of a doctoral programme. There are no restrictions on citizenship.

Level of Study: Doctorate

Type: Fellowship

Value: UK£2,500

Length of Study: Requires at least 8 months' work in a country other than that in which the applicant was educated or habitually resides Frequency: Dependent on funds available

Study Establishment: An approved Institute of Higher Education Country of Study: United Kingdom

No. of awards offered: 1

Application Procedure: Applicants must apply through their respective federation or association. A list of IFUW national federations and associations can be obtained from the IFUW website. IFUW independent members and others must apply directly to the IFUW headquarters in Geneva.

Closing Date: The deadline varies by country, but normally falls between April and May. Please ask your national headquarters for the exact deadline. The IFUW deadline for Independent members and others is June 15th

Funding: Private

Contributor: British Federation of Women Graduates

\section{The CFUW/A Vibert Douglas International Fellowship}

Subjects: Conservation biology, ecology and evolution.

Purpose: To encourage advanced scholarship and original research relevant to IFUW's mission.

Eligibility: Open to female applicants who are either members of one of IFUW's national federations or associations or, in the case of female graduates living in countries where there is not yet a national affiliate, independent members of IFUW, or other applicants who pay a filing fee. Applicants should have completed at least the first year of a doctoral programme.

Level of Study: Postdoctorate, Doctorate, Postgraduate

Type: Fellowship

Value: Canadian $\$ 12,000$

Length of Study: Requires 8-12 months' work in a country other than that in which the applicant was educated or habitually resides

Frequency: Dependent on funds available

Study Establishment: An approved Institute of Higher Education

Country of Study: Worldwide

No. of awards offered: 1
Application Procedure: Applicants must apply through their respective federation or association. A list of IFUW national federations and associations can be obtained from the IFUW website. IFUW independent members and others must apply directly to the IFUW headquarters in Geneva.

Closing Date: The deadline varies by country, but normally falls between April and May. Please ask your national headquarters for the exact deadline. The IFUW deadline for Independent members and others is June 15 th

Funding: Private

Contributor: Canadian Federation of University Women

\section{Daphne Purves (NZFGW) Grant}

Subjects: All subjects.

Purpose: To be used for specialized training, independent research, or to assist in the completion of a doctoral programme. Programme must be relevant to IFUW's mission.

Eligibility: Open to female applicants who are either members of one of IFUW's national federations or associations or, in the case of female graduates living in countries where there is not yet a national affiliate, independent members of IFUW, or other applicants who pay a filing fee. Applicants should have completed at least the first year of a doctoral programme.

Level of Study: Doctorate

Type: Grant

Value: Swiss Franc 4,000-6,000

Length of Study: Requires at least 2 months' work in a country other than that in which the applicant was educated or habitually resides

Frequency: Dependent on funds available

Study Establishment: An approved Institute of Higher Education Country of Study: Worldwide

No. of awards offered: Dependent upon funds available

Application Procedure: Applicants must apply through their respective federation or association. A list of IFUW national federations and associations can be obtained from the IFUW website. IFUW independent members and others must apply directly to the IFUW headquarters in Geneva.

Closing Date: October 1st

Funding: Private

Contributor: New Zealand Federation of Graduate Women

Additional Information: The deadline varies by country, but normally falls between April and May. Please ask your national headquarters for the exact deadline. The IFUW deadline for Independent members and others is June 15th.

\section{Dorothy Leet Grants}

Subjects: All subjects.

Purpose: To encourage advanced scholarship and original research relevant to IFUW's mission. Reserved for women graduates from countries with a comparatively low per capita income and for those who either wish to work as experts in these countries or whose research is of value to such countries.

Eligibility: Reserved for women graduates from countries with a comparatively low per capita income and for those who either wish to work as experts in these countries or whose research is of value to such countries; AND to female applicants who are either members of one of IFUW's national federations or associations or, in the case of female graduates living in countries where there is not yet a national affiliate, independent members of IFUW, or other applicants who pay a filing fee. Applicants should have completed at least the first year of a doctoral programme.

Level of Study: Doctorate, Graduate

Type: Grant

Value: Swiss Franc 4,500

Length of Study: Requires at least 2 months' work in a country other than that in which the applicant was educated or habitually resides Frequency: Dependent on funds available

Study Establishment: An approved Institute of Higher Education Country of Study: Worldwide

No. of awards offered: Varies

Application Procedure: Applicants must apply through their respective federation or association. A list of IFUW national federations and associations can be obtained from the IFUW website. IFUW independent members and others must apply directly to the IFUW headquarters in Geneva. 
Closing Date: The deadline varies by country, but normally falls between April and May. Please ask your national headquarters for the exact deadline. The IFUW deadline for Independent members and others is June 15th

Funding: Private

Contributor: International Federation of University Women

Additional Information: Further information is available from the website www.ifuw.org/what/fellowships/international.

\section{Ida Smedley MacLean Fellowship}

Subjects: All subjects.

Purpose: To encourage advanced scholarship and original research relevant to IFUW's mission.

Eligibility: Open to female applicants who are either members of one of IFUW's national federations or associations or, in the case of female graduates living in countries where there is not yet a national affiliate, independent members of IFUW, or other applicants who pay a filing fee. Applicants should have completed at least the first year of a doctoral programme.

Level of Study: Doctorate

Type: Fellowship

Value: Swiss Franc 8,000

Length of Study: More than 8 months

Frequency: Dependent on funds available

Study Establishment: An approved Institute of Higher Education

Country of Study: Worldwide

No. of awards offered: Varies

Application Procedure: Applicants must apply through their respective federation or association. A list of IFUW national federations and associations can be obtained from the IFUW website. IFUW independent members and others must apply directly to the IFUW headquarters in Geneva.

Closing Date: The deadline varies by country, but normally falls between April and May. Please ask your national headquarters for the exact deadline. The IFUW deadline for Independent members and others is June 15th

Funding: Private

Contributor: British Federation of Women Graduates

No. of awards given last year: 1 of each fellowship

Additional Information: Please see the website for further details www.ifuw.org/what-we-do/grants-fellowships/international-awards/.

\section{Winifred Cullis Grant}

Subjects: All subjects

Purpose: To be used for specialized training, independent research, or to assist in the completion of a doctoral programme. Programme must be relevant to IFUW's mission.

Eligibility: Open to female applicants who are either members of one of IFUW's national federations or associations or, in the case of female graduates living in countries where there is not yet a national affiliate, independent members of IFUW, or other applicants who pay a filing fee. Applicants should have completed at least the first year of a doctoral programme. Applicants must have completed at least 1 year of a doctoral programme.

Level of Study: Doctorate

Type: Grant

Value: $\$ 3,000-6,000$

Length of Study: Requires at least 2 months' work in a country other than that in which the applicant was educated or habitually resides Frequency: Dependent on funds available

Study Establishment: An approved Institute of Higher Education Country of Study: Worldwide

No. of awards offered: Dependent upon funds available Application Procedure: Applicants must apply through their respective federation or association. A list of IFUW national federations and associations can be obtained from the IFUW website. IFUW independent members and others must apply directly to the IFUW headquarters in Geneva.

Funding: Private

Contributor: International Federation of University Women

Additional Information: The deadline varies by country, but normally falls between April and May. Please ask your national headquarters for the exact deadline. The IFUW deadline for Independent members and others is June 15th.

\section{INTERNATIONAL FOUNDATION FOR ETHICAL RESEARCH (IFER)}

53 West Jackson Boulevard, Suite 1552, Chicago, IL, 60604, United States of America

Tel: (1) 3124276025

Fax: (1) 3124276524

Email: ifer@navs.org

Website: www.ifer.org

The International Foundation for Ethical Research (IFER) supports the development and implementation of viable, scientifically valid alternatives to the use of animals in research, product testing and classroom education. IFER is dedicated to the belief that through new technologies and diligent research, solutions can be found that will create a better world for all, without using animals.

\section{IFER Graduate Fellowship Program}

Subjects: Sciences, humanities, psychology, journalism, and the law Purpose: The purpose of these Graduate Fellowships in Alternatives in Scientific Research is to provide monetary assistance to graduate students whose programs of study seem likely to have an impact in one or more of these areas.

Eligibility: Application is open to students enroled in Master's and PhD programs in the sciences, humanities, psychology, journalism, and the law.

Level of Study: Graduate, Postgraduate

Type: Fellowship

Value: Up to US $\$ 12,500$ in stipendiary support and up to $\$ 2,500$ for supplies per year

Length of Study: 1 year, renewable for up to 3 years based on

eligibility and funding

Frequency: Annual

Country of Study: Any country

No. of awards offered: Varies

Application Procedure: Applicants must write for details or refer to the website www.ifer@navs.org.

Closing Date: March 30th (check with website)

Funding: Private

Additional Information: Please see the website for further details www.ifer.org/fellowships.php.

\section{INTERNATIONAL FOUNDATION FOR SCIENCE (IFS)}

Karlavägen 108, 5th Floor, Stockholm, SE 115 26, Sweden

Tel: (46) 854581800

Fax: (46) 854581801

Email: info@ifs.se

Website: www.ifs.se

Contact: Director

Founded in 1972, the International Foundation for Science (IFS), a non-government organization, has its largest presence in developing countries where it contributes to the strengthening of capacity to conduct relevant and high-quality research on the management, use and conservation of biological resources and the environment in which these resources occur and upon which they depend.

\section{IFS Research Grants}

Subjects: Aquatic resources, animal production, crop science, forestry/agroforestry, food science, water resources, social science and natural products.

Purpose: To provide opportunities for young researchers to contribute to the generation of scientific knowledge.

Eligibility: Applicants must be citizens of a developing country that is eligible for IFS support, and carry out the research in an eligible country (this does not have to be the country of citizenship).

Level of Study: Postdoctorate, Research

Type: Research grant

Value: Up to US\$12,000

Length of Study: $1-3$ years

No. of awards offered: Varies

Application Procedure: Applications can be downloaded from the IFS website. 
Closing Date: January 27th

Funding: Foundation

Contributor: International Foundation for Science

No. of awards given last year: 263

No. of applicants last year: 1,500

Additional Information: Please see the website for further details http://ifs.se/IFS/Documents/Calls/IFS_Call_for_Individual_ Applications_Dec2013.pdf.

\section{INTERNATIONAL HARP CONTEST IN ISRAEL}

16 Hanaziv Street, Tel Aviv, 67018, Israel

$$
\text { Tel: (972) } 36041808
$$$$
\text { Fax: (972) } 36041688
$$

Email: harzimco@netvision.net.il

Website: www.harpcontest-israel.org.il

The International Harp Contest takes place in Israel every 3 years and is judged by a jury of internationally known musicians. It was founded in 1959, and since then, harpists from all over the world gather in Jerusalem to participate in the contest, the only one of its kind.

\section{International Harp Contest in Israel}

Subjects: Harp playing.

Purpose: To encourage excellence in harp playing.

Eligibility: Open to harpists of any nationality who are aged 35 years or younger.

Level of Study: Professional development

Type: Prize

Value: $\$ 5,000$ cash prize (See website for details)

Frequency: Every 3 years

Country of Study: Any country

No. of awards offered: 1

Application Procedure: Applicants must complete an application form and submit this with recommendations, a record of concert experience, curriculum vitae and birth certificate. There is a registration fee of US\$150.

Closing Date: December 31st (check with website)

Funding: Government, private, trusts

Contributor: Culture Authority, the Government of Israel, the Ministry of Culture, foundations and donors

No. of awards given last year: 6

No. of applicants last year: 36

Additional Information: Please see the website for further details www.harpcontest-israel.org.il/.

\section{THE INTERNATIONAL HUMAN FRONTIER SCIENCE PROGRAM (HFSP)}

12 quai Saint-Jean, BP 10034, F-67080 Strasbourg Cedex, France Tel: (33) 388215126

Fax: (33) 388215289

Email: communications@hfsp.org

Website: www.hfsp.org

Contact: Rosalyn Huie, Communications Assistant

The Human Frontier Science Program (HFSP) promotes basic research in the life sciences that is original, interdisciplinary and requires international collaboration. The support and training of young investigators is given special emphasis.

\section{HFSP Cross-Disciplinary Fellowships}

Subjects: Life sciences, biology. The aim is to support basic research focused on elucidating the complex mechanisms of living organisms. The fields supported range from biological functions at the molecular level to higher brain functions.

Purpose: Cross-Disciplinary Fellowships are intended for postdoctoral fellows with a PhD in the physical sciences, chemistry, mathematics, engineering or computer science who wish to receive training in biology. The fellowships provide young scientists with up to 3 years of postdoctoral research training in an outstanding laboratory in another country. The conditions are the same as for Long-Term Fellowships.
Eligibility: For details, see HFSP website.

Level of Study: Postdoctorate

Type: Fellowship

Value: Approx. US $\$ 50,000$ per year, including allowances for travel and research expenses

Length of Study: 3 years

Frequency: Annual

Country of Study: Nationals of one of the supporting countries can apply to receive training in any country. Nationals of any other country must apply to train in a supporting country.

No. of awards offered: Varies

Application Procedure: Applications must be submitted online.

Closing Date: August (see website)

Funding: Government

Contributor: Member countries: Australia, Canada, France, Germany, India, Italy, Japan, New Zealand, Norway, Republic of Korea, Singapore, Switzerland, UK, USA, European Union

No. of awards given last year: 6

No. of applicants last year: 54

Additional Information: Fellowships for up to 3 years. The 3rd year can be used to support 1 year of postdoctoral training in the home country and can be deferred for up to 2 years. Former awardees are eligible to apply for a Career Development Award upon repatriation to their home country or when moving to another HFSP member country to help establish themselves as individual investigators.

\section{HFSP Long-Term Fellowships}

Subjects: Life sciences, biology. The aim is to support basic research focused on elucidating the complex mechanisms of living organisms. The fields supported range from biological functions at the molecular level to higher brain functions.

Purpose: Long-Term Fellowships provide young scientists with up to 3 years of postdoctoral research training in an outstanding laboratory in another country.

Eligibility: Applicants must see the website for details.

Level of Study: Postdoctorate

Type: Fellowship

Value: Approx. US $\$ 50,000$ per year, including allowances for travel and research expenses

Length of Study: 3 years

Frequency: Annual

Country of Study: Nationals of one of the supporting countries can apply to receive training in any country. Nationals of any other country must apply to train in a supporting country.

No. of awards offered: Varies

Application Procedure: Applications must be submitted online through the website.

Closing Date: August (see website)

Funding: Government

Contributor: Member countries: Australia, Canada, France, Germany, India, Italy, Japan, New Zealand, Norway, Republic of Korea, Singapore, Switzerland, UK, USA, European Union

No. of awards given last year: 69

No. of applicants last year: 643

Additional Information: Fellowships for up to 3 years. The 3rd year can be used to support 1 year of postdoctoral training in the home country and can be deferred up to 2 years. Former awardees are eligible to apply for a Career Development Award upon repatriation to their home country or when moving to another HFSP member country to help establish themselves as independent investigators. Nationals of one of the supporting countries can apply to receive training in any country. Nationals of any other country must apply to train in a supporting country.

\section{HFSP Program Grant}

Subjects: Life sciences, biology. The aim is to support basic research focused on elucidating the complex mechanisms of living organisms. The fields supported range from biological functions at the molecular level to higher brain functions.

Purpose: To enable teams of independent researchers at any stage of their careers to develop new lines of research.

Eligibility: Independent investigators early on in their careers are encouraged to apply.

Level of Study: Research

Type: Collaborative research grant 
Value: Up to US $\$ 450,000$ per grant per year Length of Study: Max. 3 years

Frequency: Annual

Country of Study: The Principal applicant must have his/her

laboratory in a member country. Atleast one other team member must be located in another country.

No. of awards offered: Varies

Application Procedure: Application online, by letter of intent; submission of full application by invitation.

Closing Date: Spring. See website for details

Funding: Government

Contributor: Member countries: Australia, Canada, France,

Germany, India, Italy, Japan, New Zealand, Norway, Republic of

Korea, Singapore, Switzerland, UK, USA, European Union

No. of awards given last year: 25

No. of applicants last year: 672 letters of intent 65 full applications received

\section{HFSP Young Investigator Grant}

Subjects: Life sciences, biology. The aim is to support basic research focused on elucidating the complex mechanisms of living organisms. The fields supported range from biological at the molecular level to higher brain functions.

Purpose: Young investigator grants are awarded to teams of researchers, all of whom are within the first 5 years of obtaining an independent position (e.g. Assistant Professor, Lecturer or equivalent). They must also be within 10 years of receiving their $\mathrm{PhD}$ before the deadline for submission of the letter of intent.

Level of Study: Research

Type: Collaborative research grant

Value: Up to US $\$ 450,000$ per grant, per year

Length of Study: Maximum 3 years

Frequency: Annual

Country of Study: The Principal applicant must have his/her laboratory in a member country. Atleast one other team member must be located in another country.

No. of awards offered: Varies

Application Procedure: Application online by letter of intent; submission of full application by invitation.

Closing Date: Spring. See website for details

Funding: Government

Contributor: Member countries: Australia, Canada, France, Germany, India, Italy, Japan, New Zealand, Norway, Republic of Korea, Singapore, Switzerland, UK, USA, European Union

No. of awards given last year: 7

No. of applicants last year: 199 letters of intent and 22 full applications

\section{INTERNATIONAL INSTITUTE FOR APPLIED SYSTEMS ANALYSIS (IIASA)}

\author{
Schlossplatz 1 A-2361, Laxenburg, Austria \\ Tel: (43) 22368070 \\ Fax: (43) 223671313 \\ Email: ysspinf@iiasa.ac.at/huber@iiasa.ac.at \\ Website: www.iiasa.ac.at
}

The International Institute for Applied Systems Analysis (IIASA) is a non-governmental research organization. It conducts inter-disciplinary scientific studies on environmental, economic, technological and social issues in the context of human dimensions of global change. It is located in Austria near Vienna.

\section{IIASA Postdoctoral Program}

Subjects: Environment, economics, technology and social issues. Purpose: To enrich IIASA's intellectual environment and help achieve research programme goals and to encourage and promote the development of young researchers and offer them the opportunity to further their careers by gaining hands-on professional research experience in a highly international scientific environment.

Eligibility: Open to candidates who have an advanced university degree equivalent to a PhD.

Level of Study: Postdoctorate

Type: Funding support
Value: Allowance for relocation expenses to and from Laxenburg, limited support for business travel and salary

Length of Study: 1-2 years

Frequency: Annual

No. of awards offered: 4

Application Procedure: Candidates must fill a personal information form online. In addition to this a research plan, a discussion of the relevance, a letter of support and names of 3 referees should be mailed.

Closing Date: April 1st, October 1st

Additional Information: Please see the website for further details www.iiasa.ac.at/web/home/education/postdoctoralProgram/ PostdocOpportunities/Application-and-Selection-Process-of-theIIASA-Funded.en.html.

For further information contact:

Website: www.iiasa.ac.at

Contact: Barbara Hauser, Postdoctoral Co-ordinator

\section{Young Scientists Summer Program (YSSP)}

Subjects: To talented young researchers whose interests correspond with IIASA's ongoing research on issues of global environmental, economic and social change.

Purpose: IIASA's annual 3-month YSSP offers research opportunities to talented young researchers whose interests correspond with IIASA's ongoing research on issues of global environmental, economic and social change. From June through August accepted participants work within the Institute's research programs under the guidance of IIASA scientific staff.

Eligibility: Candidates should have research experience corresponding to a level typical of a researcher about 2 years prior to receiving a $\mathrm{PhD}$ or equivalent degree. Candidates already holding a $\mathrm{PhD}$ degree (by January 13th) are asked to consider applying to IIASA'spostdoc program. Candidates should have a summer research proposal that clearly fits the research agenda of a selected IIASA; ability to work independently as well as interact with other scientists; fluency in English and ability to communicate in a scientific environment; willingness to actively participate in a broad range of interdisciplinary scientific activities at IIASA.

Level of Study: Research

Value: Most of IIASA's National Member Organizations (NMO) provide special grants to enable young scientists (either their own nationals or foreign students studying in their country) to participate in the YSSP. IIASA does not charge a tuition fee. Travel expenses from and to the home institution are usually covered by the NMOs in addition to the local costs covered by the grant. Students usually require a total sum of around $€ 5,000-5,500$ on average to cover all the living and travel expenses related to their YSSP participation

Length of Study: 3 months

Country of Study: Austria

No. of awards offered: $50-55$

Application Procedure: The mode of applying is online.

Closing Date: January 12th

Additional Information: YSSP participants must have valid medical insurance for their stay in Austria and should bring their insurance cards or certificates with them. Candidates will be informed about acceptance of their applications by March 10th.

\section{INTERNATIONAL INSTITUTE FOR MANAGEMENT DEVELOPMENT (IMD)}

Chemin de Bellerive 23, PO Box 915, Lausanne, $\mathrm{CH}-1001$, Switzerland

Tel: (41) 216180298

Fax: (41) 216180615

Email: mbainfo@imd.ch

Website: www.imd.ch/mba

Contact: Suzanne Laurent

The International Institute for Management Development (IMD), created by industry to serve industry, develops cutting-edge research and programmes that meet real world needs. Their clients include dozens of leading international companies and their experienced faculty incorporate new management practices into the small and 
exclusive MBA programme. With no nationality dominating, IMD is truly global, practical and relevant.

\section{IMD MBA Alumni Scholarships}

Subjects: MBA.

Purpose: To financially support applicants from Africa, Middle East, Asia, Latin America, Eastern Europe, Western Europe, North America and Oceania undertaking an MBA at IMD.

Eligibility: Candidates who have already applied to the full-time IMD MBA program and who are citizens, but not necessarily current residents Africa/Middle East, Asia, Eastern Europe, Latin America, Western Europe/North America/Oceania.

Level of Study: Graduate, MBA

Type: Scholarship

Value: Swiss Franc 30,000 towards tuition and living expenses

Length of Study: 1 year

Frequency: Annual

Study Establishment: IMD

Country of Study: Switzerland

No. of awards offered: 5

Application Procedure: Applicants must complete and submit the IMD MBA application form for financial assistance and the MBA application form. In addition, applicants must submit an essay of 1000 words on the topic: Identify one issue in your region/country which you consider a priority to address. Why would you choose this issue? How would you, as a business leader, personally address it and ensure your action has a sustainable impact?

Closing Date: September 30th

Funding: Private

Contributor: IMD Alumni Loan Fund

No. of awards given last year: 5

No. of applicants last year: 48

Additional Information: Scholarship essays, or questions, should be sent to mbafinance@imd.org. Please see the website for further details www.imd.org/mba-admission-fees/\#tab $=3$.

\section{The IMD MBA Future Leaders Scholarships}

Subjects: MBA.

Purpose: To financially support candidates with exceptionally strong leadership potential undertaking an MBA at IMD.

Eligibility: Candidates who have already applied to the full-time IMD MBA program and who demonstrate exceptionally strong leadership potential.

Level of Study: MBA

Type: Scholarship

Value: Swiss Franc 30,000 towards tuition fees and book expenses Length of Study: 1 year

Frequency: Annual

Study Establishment: IMD

Country of Study: Switzerland

No. of awards offered: 3

Application Procedure: Applicants must submit an essay of maximum of 750 words on the topic: It has been said that success in business requires flexibility to be responsive, but also commitment to a recognized set of values. Discuss using your personal and professional experience.

Closing Date: September 30th

Funding: Private

No. of awards given last year: 3

No. of applicants last year: 62

Additional Information: Scholarship essays, or questions, should be sent to mbafinance@imd.org. Please see the website for further details www.imd.org/mba.

\section{IMD MBA Merit Scholarships}

Subjects: MBA.

Purpose: To financially support applicants who consistently demonstrate exceptional qualities.

Eligibility: Candidates who have already completed the IMD MBA application and admission process.

Level of Study: MBA

Type: Scholarship

Value: Swiss Franc 10,000 towards tuition

Length of Study: 1 year

Frequency: Annual
Study Establishment: IMD

Country of Study: Switzerland

No. of awards offered: 5 awards

Closing Date: September 30th

Funding: Private

No. of awards given last year: 4

\section{Jim Ellert Scholarship}

Subjects: MBA.

Purpose: To financially support candidates from Africa, Central \&

Eastern Europe and the South Eastern Peninsula undertaking an MBA at IMD.

Eligibility: Candidates who have already applied to the full-time IMD MBA program and who demonstrate strong financial need (with preference given to women).

Level of Study: MBA

Type: Scholarship

Value: Swiss Franc 20,000

Length of Study: 1 year

Frequency: Annual

Study Establishment: IMD

Country of Study: Switzerland

No. of awards offered: 1

Application Procedure: Applicants must complete and submit the IMD MBA application form for financial assistance and the MBA application form. In addition, candidates must submit a 500-word essay on the topic: Why I would like to do an MBA at IMD.

Closing Date: September 30th

Funding: Private

No. of awards given last year: 1

No. of applicants last year: 16

Additional Information: Scholarship essays, or questions, should be sent to mbafinance@imd.org. Please see the website for further details www.imd.org/mba.

\section{Nestlé Scholarship for Women}

Subjects: MBA.

Purpose: To financially support women applicants with financial need undertaking an MBA at IMD.

Eligibility: Women candidates who have already applied to the fulltime IMD MBA program and who demonstrate financial need.

Employees of Nestlé and its subsidiaries are not eligible.

Level of Study: Graduate, MBA

Type: Scholarship

Value: Swiss Franc 25,000 towards tuition and living expenses

Length of Study: 1 year

Frequency: Annual

Study Establishment: IMD

Country of Study: Switzerland

No. of awards offered: 1

Application Procedure: Applicants must complete and submit the IMD MBA application form for financial assistance and the MBA application form. In addition, applicants must submit a 750 word on the topic: Many have argued that greater diversity in the top management team of an organization is good for profits and customers. What would you recommend as ways to achieve greater diversity?

Closing Date: September 30th

Funding: Corporation

No. of awards given last year: 1

No. of applicants last year: 9

Additional Information: Scholarship essays, or questions, should be sent to mbafinance@imd.org. Please see the website for further details www.imd.org/programs/mba/fees/scholarships/Nestle.cfm.

\section{Staton Scholarship}

Subjects: MBA.

Purpose: To financially support applicants from South America (excluding Brazil) undertaking an MBA at IMD.

Eligibility: Candidates from South America (excluding Brazil) who have already applied to the full-time IMD MBA program, on condition that the candidate must return to South America for at least 3 years after graduation.

Level of Study: Graduate, MBA

Type: Scholarship

Value: US $\$ 50,000$ towards tuition fees and expenses 
Length of Study: 1 year

Frequency: Annual

Study Establishment: IMD

Country of Study: Switzerland

No. of awards offered: 1

Application Procedure: Applicants must complete and submit the IMD MBA application form. In addition, applicants must submit a 750word essay on the topic: The role of entrepreneurship in moving my country forward and my contribution to that goal.

Closing Date: September 30th

Funding: Private

Contributor: Woods Staton

No. of awards given last year: 1

No. of applicants last year: 2

Additional Information: It is a condition of the scholarship that candidates return to South America for at least 3 years after graduation. Scholarship essays, or questions, should be sent to mbafinance@imd.org. Please see the website for further details www.imd.org/mba.

\section{Stewart Hamilton Scholarship}

\section{Subjects: MBA}

Purpose: Financially support applicants who demonstrate an understanding of corporate governance and responsibility.

Eligibility: Candidates who have already applied to the full-time IMD MBA program and who demonstrate financial need.

Level of Study: MBA

Type: Scholarship

Value: Swiss Franc 20,000

Length of Study: 1 year

Frequency: Annual

Study Establishment: IMD

Country of Study: Switzerland

No. of awards offered: 1 award

Application Procedure: Applicants must complete and submit the IMD MBA application form for financial assistance and the MBA application form.

Closing Date: September 30th

Funding: Private

No. of awards given last year: 1

No. of applicants last year: 14

Additional Information: Scholarship essays or questions should be sent to mbafinance@imd.org.

\section{INTERNATIONAL NAVIGATION ASSOCIATION (PIANC)}

Bâtiment Graaf de Ferraris - 11ième étage, Blvd. du Roi Albert II, 20 - Boîte 3, B-1000 Brussels, Belgium

Tel: (32) 25537161

Fax: (32) 25537155

Email: info@pianc.org

Website: www.pianc.org

Contact: General Secretariat

The International Navigation Association (PIANC) is a worldwide nonpolitical and non-profit technical and scientific organization of private individuals, corporations and national governments. PIANC's objective is to promote the maintenance and operation of both inland and maritime navigation by fostering progress in the planning, design, construction, improvement, maintenance and operations of inland and maritime waterways, ports and coastal areas for general use in industrialized and industrializing countries. Facilities for fisheries, sport and recreational navigation are included in PIANC's activities.

\section{De Paepe-Willems Award}

Subjects: The design, construction, improvement, maintenance or operation of inland and maritime waterways such as rivers, estuaries, canals, port, inland and maritime ports and coastal areas and related fields.

Purpose: To encourage young professionals to submit for presentation outstanding technical articles in the fields of interest to PIANC. Eligibility: Applicant must not have reached the age of forty on December 31st of the year of submission of the paper, submit his/her paper, attached to the application form, to the General Secretariat of
PIANC before the August 31st of the year preceding the granting of the Award and be the author or the lead author of a team.

Level of Study: Unrestricted

Type: Award

Value: The Award consists of an amount of $€ 5,000$ and free

membership of PIANC for a 5-year period

Frequency: Annual

Country of Study: Any country

No. of awards offered: 1

Application Procedure: Applicants must complete an application form, available on request from the PIANC General Secretariat or on the PIANC website at www.pianc.org/awardsdepaepewillemsapplicationform.asp, and submit this together with the article. Articles must be written by a single author, not have been previously published elsewhere, not exceed 12,000 words, be in type script, and in English or French with a summary in the same language. Articles may be accompanied by illustrations or diagrams.

Closing Date: August 31st

Funding: Government, private

Additional Information: The prize will be awarded to the individual candidate who submits the most outstanding article in the calendar year preceding the Annual General Assembly at which the prize is awarded, provided the article is judged to be of sufficiently high standard. The prize winner will be invited to present a commentary on his or her article during the General Assembly of the PIANC or during the Congress. In judging the articles the jury shall take into account their technical level, originality and practical value and the quality of presentation. Candidates are advised that the Bulletin is designed for readers with a wide range of engineering interests and highly specialized articles should be written with this in mind.

\section{INTERNATIONAL PEACE SCHOLARSHIP FUND}

\author{
PEO, 3700 Grand Avenue, Des Moines, IA, 50312, \\ United States of America \\ Tel: (1) 5152553153 \\ Fax: (1) 5152553820 \\ Website: www.peointernational.org
}

Contact: Ms Jaime Jensen, Project Supervisor

We are a philanthropic and educational organization who offers grants, loans and scholarships for women.

\section{PEO International Peace Scholarship}

Subjects: All subjects.

Purpose: To support international women studying for graduate degrees in USA or Canada.

Eligibility: Applicants of any nationality may apply, with the exception of residents of the US or Canada. Eligibility is based on financial need, nationality, degree, full-time status and residence. Students who hold permanent residency in the US or Canada are ineligible.

Level of Study: Doctorate, Graduate, MBA

Type: Scholarship (grant-in-aid)

Value: US $\$ 10,000$ maximum per year

Length of Study: A maximum of 2 years

Frequency: Annual

Country of Study: United States of America or Canada

No. of awards offered: Approx. 200

Application Procedure: Eligibility must be established before application material is sent. Eligibility information is available online at www.peointernational.org. Click on 'P.E.O Project/Philanthropies' and scroll down to the International Peace Scholarship Fund. Please read the qualifications and restrictions. The completed Eligibility Form must be submitted between September 15th and December 15th. If the applicant is deemed eligible, the application material will be sent. Closing Date: Please check the website

Funding: Private

Contributor: PEO members

No. of awards given last year: 164

No. of applicants last year: 419

Additional Information: Scholarships cannot be used for travel, research dissertations, internships or practical training. Applicants must also have round-trip return travel expense guaranteed at the time of the application and promise to return to their own country 
within 60 days of completion of their studies, depending on visa status, unless approved for optional practical training (OPT). Application material includes the Application Form, Personal Statement (Progress report for renewals), Educational/Employment Resume, Recommendations and Return Travel Guarantee Form.

\section{INTERNATIONAL READING ASSOCIATION}

800 Barksdale Road, PO Box 8139, Newark, DE, 19714 8139, United States of America

Tel: (1) 3027311600 ext. 423

Fax: (1) 3027311057

Email: research@reading.org

Website: www.reading.org

The International Reading Association seeks to promote high levels of literacy for all by improving the quality of reading instruction through studying the reading processes and teaching techniques, serving as a clearing house for the dissemination of reading research through conferences, journals and other publications and actively encouraging the lifetime reading habit.

\section{IRA Albert J Harris Award}

Subjects: Reading and literacy.

Purpose: To recognize outstanding published works focused on the identification, prevention, assessment, or instruction of learners experiencing difficulty learning to read or write.

Eligibility: Open to all literacy professionals.

Level of Study: Postgraduate, Research

Type: Award

Value: US $\$ 800$

Frequency: Annual

Country of Study: Any country

No. of awards offered: 1

Application Procedure: Applicants must obtain guidelines with specific information from the main address or by visiting the website. Closing Date: September 1st

Funding: Private

Additional Information: For additional information, contact research@reading.org. Please see the website for further details www. reading.org/resources/AwardsandGrants/albert___harris_award.aspx.

\section{IRA Dina Feitelson Research Award}

\section{Subjects: Literacy.}

Purpose: To recognize an outstanding empirical study that was published in English in a refereed journal that specifically reports on an investigation of aspects of literary acquisition such as phonemic awareness, the alphabetic principle, bilingualism, home influences on literacy development or cross-cultural studies of beginning reading. Eligibility: Articles must have been published in a refereed journal within the past 18 months and may be submitted by the author or anyone else. Empirical studies involve the collection of original data from direct experimentation or observation, and articles that develop theory without data, secondary reviews of the literature or descriptions of the theory are not eligible for this competition. Nominees for this award do not need to be members of the International Reading Association.

Level of Study: Unrestricted, Research

Type: Award

Value: US $\$ 500$

Frequency: Dependent on funds available

Country of Study: Any country

No. of awards offered: 1

Application Procedure: Applicants must obtain guidelines with specific information from the main address or by visiting the website. Closing Date: September 1st

\section{Funding: Private}

Additional Information: For additional information, contact research@reading.org. Please see the website for further details www. reading.org/resources/AwardsandGrants/research_feitelson.aspx.

\section{IRA Elva Knight Research Grant}

Subjects: Literacy and reading.

Purpose: To assist a researcher in a reading and literacy project that addresses significant questions about literacy instruction and practice.
Eligibility: Applicants must be members of the International Reading Association.

Level of Study: Postgraduate, Research

Value: Up to US $\$ 8,000$

Length of Study: 2 years

Frequency: Annual

Country of Study: Any country

No. of awards offered: Up to 2 awards

Application Procedure: The applicants can complete and submit their applications online using a web-based grant management system. Applicants may apply for more than one research grant; however, you are eligible to win one research grant per award year. Closing Date: November 5th

Funding: Private

Additional Information: Please see the website for further details www.reading.org/resources/AwardsandGrants/research_knight.aspx.

\section{IRA Helen M Robinson Grant}

Subjects: Literacy education.

Purpose: To support doctoral students at the early stages of their dissertation research in the area reading and literacy.

Eligibility: Open to all doctoral students at the early stages of their dissertation research worldwide who are members of the International Reading Association.

Level of Study: Doctorate, Research

Type: Research award

Value: US $\$ 1,200$

Frequency: Annual

Country of Study: Any country

No. of awards offered: 1

Application Procedure: Submit your application through the webbased grant management system.

Closing Date: November 5th

Funding: Private

Additional Information: For additional information, contact research@reading.org. Please see the website for further details www. reading.org/resources/AwardsandGrants/research_robinson.aspx.

\section{IRA Jeanne S Chall Research Fellowship}

Subjects: Reading and literacy.

Purpose: To encourage and support doctoral research investigating issues in beginning research, readability, reading difficulty and stages of reading development.

Eligibility: Open to doctoral students who are members of the International Reading Association and are planning or beginning dissertations.

Level of Study: Doctorate, Research

Type: Fellowship

Value: US $\$ 6,000$

Frequency: Annual

Country of Study: Any country

No. of awards offered: 1

Application Procedure: Applicants must obtain guidelines with specific information from the main address or by visiting the website. Submit your application through the web-based grant management system.

Closing Date: November 5th

Funding: Private

No. of awards given last year: 1

Additional Information: For additional information, contact research@reading.org. Please see the website for further details www. reading.org/resources/AwardsandGrants/research_chall.aspx.

\section{IRA Outstanding Dissertation of the Year Award}

Subjects: Reading and literacy.

Purpose: To recognize dissertations in the field of reading and literacy.

Eligibility: Open to all doctoral students worldwide who are members of the International Reading Association and who have completed dissertations in any aspect of the field of reading or literacy between May 15th and May 14th of the previous year in which the award is to be given.

Level of Study: Doctorate

Type: Research award 
Value: US $\$ 1,000$

Frequency: Annual

Country of Study: Any country

No. of awards offered: 1

Application Procedure: Applicants must obtain guidelines with specific information from the main address or by visiting the website. Closing Date: October 1st

Funding: Private

Additional Information: For additional information, contact research@reading.org. Please see the website for further details www. reading.org/resources/AwardsandGrants/research_outstanding.aspx.

\section{IRA Steven A Stahl Research Grant}

Subjects: Literacy education.

Purpose: To encourage and support promising graduate students in their research.

Eligibility: At least 3 years of teaching experience who is conducting classroom research (including action research) focused on improving reading instruction and children's reading achievement.

Level of Study: Graduate, Research

Type: Grant

Value: US $\$ 1,000$

Frequency: Annual

Country of Study: Any country

Application Procedure: Submit your application through the webbased grant management system.

Closing Date: November 5th

Funding: Private

Additional Information: For additional information, contact research@reading.org. Please see the website for further details www. reading.org/resources/AwardsandGrants/research stahl.aspx.

\section{IRA Teacher as Researcher Grant}

Subjects: Literacy.

Purpose: To support classroom teachers in their enquiries about literacy learning and instruction.

Eligibility: All applicants must be members of the International Reading Association and practicing pre-K-12 teachers with full-time teaching responsibilities, including librarians, classroom teachers and resource teachers. Applicants are limited to one proposal per year. There must be a span of 3 years before past grant recipients can apply for another Teacher as Researcher Grant.

Level of Study: Research

Type: Research award

Value: Up to US $\$ 4,000$ maximum, but priority is given to smaller grants of between US $\$ 1,000$ and 2,000

Frequency: Annual

Country of Study: Any country

No. of awards offered: Several

Application Procedure: Applicants must obtain guidelines with specific information from the main address or by visiting the website. Submit your application through the web-based grant management system.

Closing Date: November 5th

Funding: Private

Additional Information: For additional information, contact research@reading.org. Please see the website for further details www. reading.org/resources/AwardsandGrants/research_teacher_as_ researcher.aspx.

\section{INTERNATIONAL RESEARCH AND EXCHANGE BOARD (IREX)}

2121 K Street North West, Suite 700, Washington, DC, 20037, United States of America

Tel: (1) 2026288188

Fax: (1) 2026288189

Email: irex@irex.org

Website: www.irex.org

The International Research and Exchange Board (IREX) is an international non-profit organization specializing in education, independent media, internet development and civil society programmes. Through training, partnerships, education, research and grant programmes, IREX develops the capacity of individuals to contribute to their societies. Since its founding in 1968, IREX has supported over 15,000 students, scholars, policymakers, business leaders, journalists and other professionals.

\section{IREX Individual Advanced Research Opportunities}

Subjects: Policy-relevant research in the social sciences and humanities.

Purpose: To provide opportunities for scholars from the USA wishing to pursue research in the humanities and social sciences in Europe and Eurasia.

Eligibility: Must be U.S. citizen, enroled in a graduate degree program or currently be holding a graduate degree at the time of application and must study in an eligible country.

Level of Study: Doctorate, Graduate, MBA, Postdoctorate, Postgraduate, Predoctorate, Professional development, Research

Type: Grant

Value: Up to a maximum of US $\$ 40,000$. Covers travel and visa fees, daily stipend and a housing allowance

Length of Study: Up to 9 months

Frequency: Annual

Study Establishment: Appropriate institutions

No. of awards offered: Varies

Application Procedure: Applicants must visit the website for application forms and further information.

Closing Date: December 9th

Funding: Government, private

Contributor: The U.S. Department of State (Title VIII) and the IREX Scholar Support Fund

No. of awards given last year: 25

Additional Information: Applicants must study in one of the following countries - Albania, Armenia, Azerbaijan, Belarus, Bosnia and Herzegovina, Bulgaria, Croatia, Czech Republic, Estonia, Georgia, Hungary, Kazakhstan, Kosovo, Kyrgyzstan, Latvia, Lithuania, Macedonia, Moldova, Montenegro, Poland, Romania, Russia, Serbia, Slovakia, Slovenia, Tajikistan, Turkmenistan, Ukraine, and Uzbekistan. Please see the website for further details www.internationalpeaceandconflict.org/forum/topics/fellowship-irex-2014-2015-international-fellowship-for-u-s-schola?xg_source $=$ activity\#.VRFX7fmUeSo.

\section{IREX Policy-Connect Collaborative Research Grants}

Subjects: Social sciences concerned with Europe, Eurasia, the Near East and Asia. Applicants should refer to the website as there will be a theme each year limiting the geographical focus and the eligible fields of research.

Purpose: To attract, select, and support advanced research by U.S experts in policy-relevant subject areas related to Southeast Europe and Eurasia, facilitate collaboration among and between US and international scholars, and disseminate knowledge about Europe and Eurasia to a wide network of constituents in the US and abroad. Eligibility: Open to citizens and 3-year permanent residents of the USA. Applicants must hold a PhD or other terminal graduate degree at the time of application. Collaborative research programmes involving international colleagues are strongly encouraged.

Level of Study: Postdoctorate, Postgraduate

Type: Grant

Value: Up to US $\$ 30,000$

Length of Study: Up to 1 year

Frequency: Annual

No. of awards offered: 4

Application Procedure: Applicants must contact IREX or visit the website for application forms.

Closing Date: April 1st

Funding: Government, private

Contributor: U.S. Department of State (Title VIII), John J and Nancy Lee Roberts

No. of awards given last year: 1

Additional Information: Further information is available on request. The programme is limited to specific geographic areas and topics each year. Please visit the sponsor website for the most current information: www.irex.org/programs/policy-connect/index.asp.

\section{IREX Short-Term Travel Grants}

Subjects: Policy-relevant research.

Purpose: To provide opportunities for scholars from the USA to pursue research in the social sciences in Europe and Eurasia. 
Eligibility: STG applicants must have a graduate degree $(\mathrm{PhD}, \mathrm{MA}$, MD, MBA, MFA, MPA, MPH, MLIS, MS, JD) at the time of application and must be a U.S. citizens. STG applicants may not be pursuing a degree at the time of application.

Level of Study: Postdoctorate, Postgraduate

Type: Travel grant

Value: International coach class roundtrip transportation from the US to the host country(ies) for the period of grant awarded; a monthly allowance for housing and living expenses, based on IREX's preestablished country-specific rates; travel visas; emergency evacuation insurance

Length of Study: Up to 8 weeks

Frequency: Annual

Country of Study: Eastern Europe and Eurasia

No. of awards offered: Varies

Application Procedure: Candidates must contact Amy Schulz, Program Officer, at stg@irex.org for details or application guidelines. Application forms can be downloaded from the website.

Closing Date: February 6th

Funding: Government

Contributor: The U.S. Department of State's Title VIII Program

No. of awards given last year: Approx. 40

No. of applicants last year: Varies

Additional Information: Candidates will be notified of award decisions approx. 8 weeks after the application deadline. Candidates must study in one of the following countries - Albania, Armenia, Azerbaijan, Belarus, Bosnia and Herzegovina, Bulgaria, Croatia, Czech Republic, Estonia, Georgia, Hungary, Kazakhstan, Kosovo, Kyrgyzstan, Latvia, Lithuania, Macedonia, Moldova, Montenegro, Poland, Romania, Russia, Serbia, Slovakia, Slovenia, Tajikistan, Turkmenistan, Ukraine, and Uzbekistan.

\section{INTERNATIONAL TROPICAL TIMBER ORGANIZATION (ITTO)}

International Organizations Center, 5th floor, Pacifico-Yokohama 1-1-1, Minato-Mirai, Nishi-ku, Pacifico-Yokohama, 2200012, Japan

Tel: (81) 452231110

Fax: (81) 452231111

Email: itto@itto.int

Website: www.itto.int

ITTO is an intergovernmental organization promoting the conservation and sustainable management, use and the trade of tropical forest resources.

\section{International Tropical Timber Organization (ITTO) \\ Fellowship Programme}

Subjects: Forestry management including forest industry development and trade in forest products and services.

Purpose: To promote human resource development and to strengthen professional expertise in tropical forestry.

Eligibility: Only nationals of ITTO member countries are eligible to apply, and fellowships are awarded mainly to nationals of developing member countries.

Level of Study: Doctorate, Postgraduate, Professional development, Research

Type: Fellowship

Value: Up to US $\$ 10,000$

Study Establishment: Varies

No. of awards offered: $50-60$ per year

Application Procedure: Application form must be completed and sent with required documents to the ITTO Secretariat by post.

Closing Date: February 20th

Funding: Government

Contributor: International Tropical Timber Organization

No. of awards given last year: 45

No. of applicants last year: 245

Additional Information: Eligible activities include participation in international/regional conferences, short term training courses, training internships at industries, research and educational institutions, study tours and lecture/demonstration tours; Small grants for post graduate studies. Please see the website for more details www.itto.int/ feature20/.
INTERNATIONAL UNION FOR VACUUM SCIENCE AND TECHNOLOGY (IUVSTA)

84 Oldfield Drive, Vicars Cross, Chester, $\mathrm{CH} 3$ 5LW, United Kingdom Tel: (44) 124434 2675, 7713403525 Fax: (44) 7005860135

Email: eisenmenger@ifp.tuwien.ac.at Website: www.iuvsta.org

Contact: Dr Christoph Eisenmenger-Sittner, Secretary General

The International Union for Vacuum Science and Technology (IUVSTA) is a non-government organization whose member societies represent all vacuum scientists, engineers and technologists in their country.

\section{Welch Scholarship}

Subjects: Vacuum science.

Purpose: To encourage promising scholars who wish to study vacuum science, techniques or their application in any field Eligibility: Open to applicants of any nationality who hold the minimum of a Bachelor's degree, although preference is given to those holding a doctoral degree.

Level of Study: Postgraduate, Doctorate, Postdoctorate

Type: Scholarship

Value: US $\$ 15,000$. The scholarship money is paid in three installments - one of $\$ 7,500$ at the beginning, another of $\$ 7,000,6$ months after he/she has started work, and a third of $\$ 500$ upon delivery of a final report after completion of work

Length of Study: 1 year

Frequency: Annual

Study Establishment: An appropriate laboratory

Country of Study: Any country

No. of awards offered: 1

Application Procedure: Applicants must complete and submit an application form with a research proposal, a curriculum vitae and two letters of reference. More information and application forms can be obtained from the website.

Closing Date: April 15th

Funding: Private

Contributor: IUVSTA

No. of awards given last year: 1

No. of applicants last year: 6

Additional Information: Researchers who applied unsuccessfully for previous Welch Scholarships may apply again. Applications for renewal of the Scholarship are not accepted.

\section{For further information contact:}

Canadian Photorics Fabrication Centre, Institute for Microstructural Sciences, National Research Council, Building M-50, Montréal Road, Ottawa, ON, K1A 0R6, Canada

Email: Frank.Shepherd@nrc-cnrc.gc.ca

Website: http://iuvsta-us.org/iuvsta2/index. php?id $=654$

Contact: Dr FR Shepherd, Administrator Technical Manager

\section{INTERNATIONAL UNION OF BIOCHEMISTRY AND MOLECULAR BIOLOGY (IUBMB)}

University of Calgary, Department of Biochemistry \& Molecular Biology, 3330 Hospital Drive NW, HM G72B, Calgary, AB T2N 4N1, Canada

Tel: (1) 4032203021

Fax: (1) 4032702211

Email: walsh@ucalgary.ca

Website: www.iubmb.org

Contact: Professor Michael P Walsh, IUBMB General Secretary

IUBMB seeks to advance the international molecular life sciences community by: Promoting interactions across the diversity of endeavours in the molecular life sciences, creating networks that transcend barriers of ethnicity, culture, gender, and economic status, creating pathways for young scientists to fulfil their potential, providing evidence-based advice on public policy, promoting the values, standards, and ethics of science and the free and unhampered movement of scientists of all nations. 


\section{Wood-Whelan Research Fellowships}

Subjects: Biochemistry and molecular biology.

Purpose: To provide financial assistance to young biochemists and molecular biologists to carry out research and training in a laboratory other than their own.

Eligibility: Open to applicants who are residents of countries that are members of IUBMB and students or young researchers less than 35 years old. Retroactive applications will not be considered.

Level of Study: Postdoctorate, Postgraduate, Research, Graduate Type: Fellowship

Value: Up to US $\$ 4,000$. It covers travel and incidental costs, as well as living expenses

Length of Study: $1-4$ months

Frequency: Annual

No. of awards offered: $10-20$

Application Procedure: Applicants must submit a completed application form along with details of the research proposal, budget, curriculum vitae with a list of publications and letters of recommendation following the guidelines which can be found at website. The original application should be sent by the applicant by email as PDF files.

Closing Date: At least 2 months before the proposed visit

Contributor: The main sources of income for IUBMB are dues from adhering bodies (member societies) and revenue from publications

No. of awards given last year: 15

No. of applicants last year: 32

Additional Information: Travel should commence within 4 months of the award being made.

For further information contact:

Email: janet.macaulay@monash.edu Contact: Dr Janet Macaulay

\section{INTERNATIONAL UNIVERSITY OF JAPAN}

777, Kokusai-cho, Minami Uonuma-shi, Niigata, 949-7277, Japan Tel: (81) 257791104

Fax: (81) 257791180

Email: info@iuj.ac.jp

Website: www.iuj.ac.jp

Contact: Gretchen W Shinoda, Manager, Office of Student Services

The mission of the International University of Japan (IUJ) is to train leaders who can make contributions to the practical resolution of global problems facing people living in various countries and regions in the world, and who work in governments, companies, and NGOs to extend public and social benefits globally.

\section{Sohei Nakayama Memorial Scholarship}

\section{(Type A, B, C, and S)}

Subjects: MBA (1-year and 2-year tracks), MA in international relations, MA in international development, MA in international peace studies, MA in public management, MA in economics, Master in E-business management and MA in economics.

Purpose: To support those who study in International University of Japan (IUJ) in one of our master's programs (MA and MBA).

Eligibility: Open to all applicants who want to study in IUJ.

Level of Study: Graduate, MBA, Postgraduate

Type: Scholarship

Value: Tuition exemption (all or partial), stipends (depending on scholarship rank)

Length of Study: Up to 2 years

Frequency: Annual

Country of Study: Japan

No. of awards offered: Varies

Application Procedure: When applicants apply to one of our seven Master's level degree programmes. Applicants also submit an online scholarship application available from the website www.iuj.ac.jp/ admis/.

Closing Date: Contact the admissions office: same as application deadlines to degree programs

Funding: Corporation, foundation, government, individuals

Contributor: The Ministry of Education, youth and sport, IUJ, ADB,

JICA, IMF, KMMF, WB, etc
No. of awards given last year: Varies

No. of applicants last year: Varies

Additional Information: Many other scholarships are facilitated by IUJ for studying at IUJ. Please see our website at www.iuj.ac.jp/admis/ scholarship.

\section{INTERNATIONAL VIOLIN COMPETITION-PREMIO PAGANINI}

Secretariat, Fondazione Teatro Carlo Felice, Passo Eugenio Montale 4, Genova, 16121, Italy

Tel: (39) 01053811

Fax: (39) 0105381363

Email: paganini@carlofelice.it

Website: www.carlofelice.it

Contact: Ms Bianca Fusco, Paganini Competition Secretariat

The international violin competition 'Premio Paganini' is a competition for young violinists between 16 and 30 years of age. It offers prizes for a total amount of $€ 40,000$ plus special prizes and an opportunity for the winner to play 'Cannone' - Paganini's violin - at the Carlo Felice Theatre during the artistic season.

\section{International Violin Competition - Premio Paganini}

Subjects: Violin

Purpose: To discover new talented young violinists and encourage them to spread the values which Paganini himself and his music stands for

Eligibility: Violinists between 16 and 30 years of age.

Level of Study: Unrestricted

Type: Prize

Value: 1st prize 'Premio Paganini' $€ 25,000.00$ (indivisible), 2nd prize $€ 10,000.00$ (indivisible), 3rd prize $€ 5,000.00$ and the other finalists will receive a sum of $€ 1,500.00$ each

Frequency: Every 2 years

Country of Study: Italy

No. of awards offered: 3 awards and special prizes

Application Procedure: Applicants must send the application form by mail together with a $C D$ and the documents required to the address indicated below. The application form and the rules of the competition may be obtained from obtained by writing to the Competition

Secretariat or they can be downloaded at website. A pre-selection will be made to enter the competition.

Closing Date: January 1st

Funding: Government

Contributor: Comune di Genova

No. of awards given last year: 2 plus prizes

No. of applicants last year: 51

\section{INTERNATIONALER ROBERT-SCHUMANN-WETTBEWERB ZWICKAU}

\author{
Stadtverwaltung Zwickau, Kulturamt, PF 200933, \\ 08009 Zwickau, Germany \\ Tel: (49) 0375834130 \\ Fax: (49) 0375834141 \\ Email: kulturbuero@zwickau.de \\ Website: www.schumann-zwickau.de
}

International Robert Schumann Competition

Subjects: Piano performance and individual singing.

Purpose: To support the interpretation of the works of Robert Schumann.

Eligibility: Open to pianists up to the age of 30 and to individual singers up to the age of 32

Level of Study: Professional development

Type: Competition

Value: Piano -3 prizes with a total amount of $€ 22,500$, Singers

(female) -3 prizes with a total amount of $€ 22,500$, Singers (male) -3 prizes with a total amount of $€ 22,500$, Special prize of $€ 3,000$ will be awarded to the best pianist

Country of Study: Any country 
No. of awards offered: 10

Application Procedure: Applicants must write for further details.

Closing Date: February 15th

Funding: Commercial, government

No. of awards given last year: 10

No. of applicants last year: 134

Additional Information: Please see the website for further details www.schumannzwickau.de.

\section{IOTA SIGMA PI}

Microelectronics Technology, Lord Corporation, 110 Lord Drive, Cary, NC, 27511, United States of America Tel: (1) 9194685979

Email: sara.paisner@lord.com

Website: www.iotasigmapi.info

Contact: Sara Paisner, Senior Scientist

lota Sigma $\mathrm{Pi}$, founded in 1902, is a National Honor Society that serves to promote the advancement of women in chemistry by granting recognition to women who have demonstrated superior scholastic achievement and high professional competence by election into lota Sigma Pi.

\section{Agnes Fay Morgan Research Award}

Subjects: Chemistry and biochemistry.

Purpose: To acknowledge research achievements in chemistry or biochemistry.

Eligibility: Open to female applicants who are not more than 40 years of age.

Level of Study: Postgraduate

Type: Award

Value: The Award will consist of $\$ 1,500$, a certificate, and member-

ship in lota Sigma Pi with a waiver of dues for 1 year

Frequency: Annual

Study Establishment: Any accredited institution

Country of Study: Any country

No. of awards offered: 1

Application Procedure: The nomination dossier must be sent

electronically (preferably as a pdf) to Dr Nancy Eddy Hopkins.

Closing Date: February 15th

Contributor: lota Sigma Pi

Additional Information: Please see the website for further details.

For further information contact:

Tel: 5048623162

Email: nhopkin@tulane.edu

Website: www.iotasigmapi.info/ISPprofawards/ISPprofawards.html

Contact: Dr Nancy Eddy Hopkins, Director for Professional Awards

\section{Anna Louise Hoffman Award for Outstanding}

Achievement in Graduate Research

Subjects: Chemistry.

Purpose: To recognize outstanding achievement in chemical research.

Eligibility: The candidate must be a full-time (as defined by the nominee's institution) woman graduate student who is a candidate for a graduate degree in an accredited institution. The research presented by the candidate must be original research which can be described by one of the main chemical divisions (e.g., analytical, biochemical,

inorganic, organic, physical, and/or ancillary divisions of chemistry).

The nominee may be, but need not be, a member of lota Sigma Pi.

Level of Study: Postgraduate

Type: Award

Value: The award will be $\$ 500$, a certificate and a waiver of dues for 1 year

Frequency: Annual

Study Establishment: Any accredited institution

Country of Study: Any country

Application Procedure: The complete dossier must be sent electronically as a single file (pdf format is recommended) to Professor Jill Nelson Granger.

Closing Date: February 15th

Contributor: lota Sigma Pi

Additional Information: Please see the website for further details.
For further information contact:

Sweet Briar College, Department of Chemistry, Sweet Briar, VA, 24595, United States of America

Tel: (1) 4343816166

Email: granger@sbc.edu

Website: www.iotasigmapi.info/ISPstudentawards/

ISPstudentawards.htm

Contact: Professor Jill Nelson Granger, Director for Student Awards

\section{Gladys Anderson Emerson Scholarship}

Subjects: Chemistry and biochemistry.

Purpose: To award excellence in chemistry or biochemistry.

Eligibility: Open to applicants who are members of lota Sigma Pi.

Level of Study: Postgraduate

Type: Scholarship

Value: US\$2,000 and a certificate

Frequency: Annual

Study Establishment: Any accredited institution

Country of Study: Any country

No. of awards offered: Up to 2 awards

Application Procedure: The complete dossier must be sent

electronically as a single file (pdf format is recommended) to Professor Jill Nelson Granger.

Closing Date: February 15th

Contributor: lota Sigma $\mathrm{Pi}$

Additional Information: Please see the website for further details.

For further information contact:

Sweet Briar College, Department of Chemistry, Sweet Briar, VA, 24595 Tel: 4343816166

Email: granger@sbc.edu

Website: www.iotasigmapi.info/ISPstudentawards/

ISPstudentawards.htm

Contact: Professor Jill Nelson Granger, National Director for Student Awards

\section{lota Sigma Pi Centennial Award}

Subjects: Chemistry, biochemistry.

Purpose: To award excellence in teaching chemistry, biochemistry or chemistry-related subjects.

Eligibility: Holds a teaching position at an institution that does not have a graduate program in her department or holds a teaching position that is for teaching undergraduates $>75$ per cent of her time at an institution that does have a graduate program in her department The nominee may be, but need not be, a member of lota Sigma Pi.

Level of Study: Postgraduate

Type: Award

Value: US $\$ 500$, a certificate and membership in lota Sigma Pi with a waiver of dues for 1 year

Frequency: Annual

Application Procedure: One copy of the nomination dossier must be sent electronically (preferably as a pdf) to Dr Nancy Eddy Hopkins.

Closing Date: February 15 th

Contributor: lota Sigma $\mathrm{Pi}$

Additional Information: Please see the website for details.

For further information contact:

Tel: 5048623162

Email: nhopkin@tulane.edu

Website: www.iotasigmapi.info/awards/professionalawards.html

Contact: Dr Nancy Eddy Hopkins, Director for Professional Awards

\section{lota Sigma Pi National Honorary Member Award}

Subjects: Chemistry.

Purpose: To honour outstanding women chemists.

Eligibility: Open to female candidate with exceptional achievements in chemistry. Applicants may or may not be members of lota Sigma Pi. Type: Award

Value: US $\$ 1,500$ a certificate and membership in lota Sigma Pi with a lifetime waiver of dues

Length of Study: Every 3 years

Frequency: Every 3 years

No. of awards offered: Varies 
Application Procedure: One copy of the nomination dossier must be sent electronically (preferably as a pdf) to Nancy Eddy Hopkins.

Closing Date: February 15th

Additional Information: Please see the website for details.

For further information contact:

Email: nhopkin@tulane.edu

Website: www.iotasigmapi.info/awards/professionalawards.html

Contact: Dr Nancy Eddy Hopkins, Director for Professional Awards

\section{Members@Large (MAL) Reentry Award}

Subjects: Chemistry.

Purpose: To recognize potential excellence in chemistry and related fields.

Eligibility: Open to a woman candidate with a degree at any level in chemistry or a related field at an accredited 4-year college or university.

Level of Study: Postgraduate

Type: Award

Value: US $\$ 1,500$, a certificate and a year's complimentary membership in lota Sigma $\mathrm{Pi}$

Frequency: Annual

Study Establishment: Any accredited institution

Country of Study: Any country

No. of awards offered: Varies

Application Procedure: A completed application form must be sent.

Closing Date: February 15th

Contributor: lota Sigma $\mathrm{Pi}$

Additional Information: Please see the website for details.

For further information contact:

Science - Chemistry, Richland Northeast High School, 7500 Brookfield Road, Columbia, SC, 29223

Website: www.ispmembersatlarge.com/members@large-re-entryaward.html

Contact: Joanne Bedlek-Anslow, MAL National Coordinator

\section{Violet Diller Professional Excellence Award}

Subjects: Chemistry.

Purpose: To recognize significant accomplishments in academic, governmental or industrial chemistry.

Eligibility: Open to female applicants who have contributed to the scientific community or society on a national level.

Level of Study: Postgraduate

Type: Award

Value: US $\$ 1,000$, a certificate and membership in lota sigma Pi with a lifetime waiver of dues

Frequency: Every 3 years

Application Procedure: One copy of the nomination dossier must be sent electronically (preferably as a pdf) to Nancy Eddy Hopkins.

Closing Date: February 15th

Contributor: lota Sigma $\mathrm{Pi}$

Additional Information: Please see the website for further details.

For further information contact:

Email: nhopkin@tulane.edu

Website: www.iotasigmapi.info/awards/professionalawards.html

\section{THE IRISH RESEARCH COUNCIL}

First Floor, Brooklawn House, Crampton Avenue (off Shelbourne Road) Ballsbridge, Dublin 4, Ireland

Tel: (353) 012315000

Fax: (353) 012315009

Email: info@research.ie

Website: www.research.ie

The Irish Research Council was formally launched by the Minister for Research and Innovation, Seán Sherlock TD, on 29 March 2012. A sub-board of the Higher Education Authority, the Council was established through a merger of the Irish Research Council for Humanities and Social Sciences (IRCHSS) and the Irish Research Council for Science, Engineering and Technology (IRCSET).

\section{Employment-Based Postgraduate Scholarship} Programme

Subjects: Scholarship is provided for any one course offered by the university.

Purpose: It offers opportunities for individuals to pursue a postgraduate degree in any discipline, at Higher Education Institution while being employed.

Eligibility: New employee of the Employment Partner scholars are selected in the council's postgraduate scholarship application and assessment process. For detailed information, please visit the website.

Level of Study: Postgraduate

Type: Scholarship

Value: $€ 24,000$

Length of Study: 12-48 months, depends on type of degree

Frequency: Annual

Country of Study: Ireland

Application Procedure: The mode of applying is online.

Closing Date: July

Funding: Government

Contributor: Department of Education and Skills

No. of awards given last year: 42

No. of applicants last year: 53

Additional Information: Applicants will be notified by late October/ November.

\section{Government of Ireland Postdoctoral Fellowship \\ Scheme}

Subjects: Research based project for 1-2 years. First year doctoral dissertation for publication. Second year develop a new research project which is a significant development from the subject of the doctorate.

Purpose: To provide funding across all disciplines for early-career researchers based in Ireland from 1 to 2 years.

Eligibility: An applicant must have achieved a research type postgraduate award from any university.

Level of Study: Doctorate

Type: Fellowship

Length of Study: 1-2 years

Frequency: Annual

Country of Study: Ireland

No. of awards offered: 600

Application Procedure: Apply online at www.research.ie.

Closing Date: November

Funding: Government

Contributor: Irish Research Council

No. of awards given last year: 600

No. of applicants last year: 800

Additional Information: Please check website for more details.

\section{IRISH RESEARCH COUNCIL FOR THE HUMANITIES AND SOCIAL SCIENCES (IRCHSS)}

First Floor, Brooklawn House, Crompton Avenue (off Shelbourne Road), Ballsbridge, Dublin, 4, Ireland

$$
\begin{gathered}
\text { Tel: (353) } 012315000 \\
\text { Fax: (353) } 012315009 \\
\text { Email: info@irchss.ie } \\
\text { Website: www.irchss.ie }
\end{gathered}
$$

Irish Research Council for the Humanities and Social Sciences (IRCHSS) was established in 2000 by the Minister for Education and Science in response to the need to develop Ireland's research capacity and skills base in a rapidly changing global environment where knowledge is the key to economic and social growth.

\section{IRCHSS Postdoctoral Fellowship}

Subjects: Humanities and social sciences.

Purpose: To encourage excellence and the highest standards in the humanities and social sciences.

Eligibility: Open to candidates of any nationality who have been awarded their Doctoral degrees within the past 5 years. 
Level of Study: Postdoctorate

Type: Fellowship

Value: $€ 30,000$ per year after tax

Length of Study: 1-2 years

Frequency: Annual

Closing Date: February 17 th

Additional Information: Applicants should be, or expect to be affiliated with a recognized higher education institution during the academic year. Please see the website for further details.

\section{IRCHSS Postgraduate Scholarship}

Subjects: Humanities and social sciences.

Purpose: To facilitate the integration of Irish researchers in the humanities and social sciences within the European

Research Area.

Eligibility: Open to citizens of Ireland or citizens of a Member State of the European Union who have been residing within Ireland for less than 3 years. The candidates should be registered as full-time postgraduate research students.

Level of Study: Postgraduate

Type: Scholarship

Value: $€ 16,000$ per year

Length of Study: 1 year

Frequency: Annual

Application Procedure: Applicants can download the application

form from the website.

Closing Date: March 20th

Additional Information: Please see the website for further details.

\section{Thematic Research Project Grants}

Subjects: Humanities and social sciences.

Purpose: To support projects that require medium to long-term support.

Eligibility: Open to academic staff employed at third-level institutions in Ireland for research project. For more details, see website.

Level of Study: Research

Type: Grant

Value: $€ 6,500-300,000$

Length of Study: Up to 3 years

Frequency: Annual

Application Procedure: Applicants can download the application form from the website and send the completed form along with a description of the project.

Closing Date: September 14th

\section{IRISH-AMERICAN CULTURAL INSTITUTE (IACI)}

1 Lackawanna Place \# 1, Morristown, NJ, 07960, United States of America

Tel: (1) 9736051991

Fax: (1) 9736058875

Email: info@iaci-usa.org

Website: www.iaci-usa.org

The Irish-American Cultural Institute (IACI), a non-profit educational institute, is dedicated to preserving and promoting the highest standards of artistic development, education, research and entertainment in fostering the cultural understanding of Irish heritage in America. With international headquarters in Morristown, NJ, the Institute has a long history of supporting the arts and humanities through grants and awards as well as through programming. The Institute is strictly non-political and non-sectarian. Founded in 1962, the IACI is the sole U.S. organization with the distinction of having the President of Ireland as patron.

\section{IACI Visiting Fellowship in Irish Studies at the National University of Ireland, Galway}

Subjects: Irish studies.

Purpose: To allow scholars whose work relates to any aspect of Irish studies who wish to spend a semester at the University of Ireland, Galway.

Eligibility: Open to scholars who normally reside in the USA, and whose work relates to any aspect of Irish studies.
Level of Study: Postdoctorate, Research

Type: Fellowship

Value: US $\$ 4,000$

Length of Study: At least 4 months

Frequency: Annual

Country of Study: Ireland

No. of awards offered: 1

Application Procedure: Applicants must complete an application form and submit this with a current curriculum vitae and list of publications. Application forms are available on request. Applications can be downloaded from the IACI website.

Closing Date: December 31st

Funding: Foundation

Contributor: Jointly funded with the National University InternationalGalway

Additional Information: The holder of the fellowship will be provided with services appropriate to a visiting faculty member during his or her time at NUI-Galway. There are certain relatively minor departmental responsibilities expected of the holder during his or her time at UCG, and certain other expectations regarding publication, upon completion of the fellowship. Please see the website for details www.iaci-usa.org/ pdf/NUI-G\%20Application\%20Letter.pdf.

\section{Irish Research Funds}

Subjects: All subjects; historical research has predominated, but other areas of research will be given equal consideration.

Purpose: To promote scholarly enquiry and publication regarding the Irish-American experience.

Eligibility: Open to individuals of any nationality. Media production costs and journal subventions will not be considered for funding.

Level of Study: Postgraduate

Type: Grant

Value: US $\$ 1,000-5,000$

Country of Study: Any country

No. of awards offered: Varies

Application Procedure: Applicants must complete an application form.

Closing Date: October 1st

Funding: Foundation

\section{THE ISLAMIC DEVELOPMENT BANK (IDB)}

PO Box 5925, Kingdom of Saudi Arabia, Jeddah, 21432, Saudi Arabia Tel: (966) 26361400

Fax: (966) 26366871

Email: idbarchives@isdb.org

Website: www.isdb.org

The Islamic Development Bank is an international financial institution, which aims to foster the economic development and social progress of member countries and Muslim countries.

\section{IDB Merit Scholarship for High Technology}

Subjects: Science and technology.

Purpose: To encourage advanced studies/research in science and high technology areas.

Eligibility: Applicant must not be over (a) 35 years for $\mathrm{PhD}$ study, and (b) 40 years for postdoctoral research.

Level of Study: Postgraduate

Type: Scholarship

Value: Tuition/bench fee, monthly living allowance, monthly family allowance (for PhD study only), clothing/books allowance (for PhD study only), installation allowance (for PhD study only), computer allowance (for $\mathrm{PhD}$ study only), conference/thesis preparation allowance and medical coverage. Round trip air-tickets to and from place of study

Frequency: Annual

No. of awards offered: Varies

Application Procedure: Download the application form for 3-year PhD study or application form for postdoctoral research. The applications must be submitted through the nominating institutions to the Office of the IDB Governor for the country. It is the Office of the IDB Governor that will forward the applications to the IDB and not the 
individual applicants or the nominating institutions. As for Egypt, applications should be forwarded through the Ministry of Higher Education, Egypt instead of Office of the IDB Governor. Applications sent directly to the IDB will not be considered.

Closing Date: December 31st

Additional Information: Please see the website www.isdb.org/irj/ portal/anonymous ? NavigationTarget $=$ navurl://c28c70fde436815fcff1257ef5982a08 for further details.

\section{IDB Scholarship Programme in Science and Technology}

Subjects: Science, technology, engineering and medicine.

Purpose: To assist IDB least developed member countries in the development of science and technology.

Eligibility: Open to candidates from least developed member countries, who are below the age of 30 years, a graduate in science/technology with a grade above Good in his/her academic career, nominated by an academic research institution of his/her country, not in receipt of another scholarship and medically fit and be willing to undergo medical tests after selection.

Level of Study: Postgraduate

Type: Scholarship

Value: The scholarship covers the tuition fees, living allowance, clothing and books allowances, computer allowance, conference allowance, medical coverage and a return air ticket

Length of Study: 2 years

Frequency: Annual

Application Procedure: Application form can be downloaded. The applications must be submitted to the Office of the IDB Governor for the country. It is the Office of the IDB Governor that will forward the applications to the IDB and not the individual applicants or the nominating institutions. Applications sent directly to the IDB will not be considered.

Closing Date: January 31st

Additional Information: Please see the website www.isdb.org/irj/ portal/anonymous? NavigationTarget $=$ navurl://ec61fd $4 \mathrm{c} 088 \mathrm{c} 45 \mathrm{fa} 5 \mathrm{e}-$ f909229a0411f4 for details.
IWHM BERNARD BUTLER TRUST FUND

48 Abingdon Road, Sandhurst, Hants, GU47 9RN, United Kingdom Tel: (44) 07884407482

Email: info@bernardbutlertrust.org

Website: www.bernardbutlertrust.org

Contact: G Porter, Trust Secretary

The Trust was established in 1998 from the assets of the Institution of Works and Highways Management after the merger of its professional activities with the Institution of Civil Engineers in 1994.

\section{The Bernard Butler Trust Fund}

Subjects: Civil and municipal engineering.

Purpose: To encourage men and women engaged in the civil and municipal engineering field to improve their education, training and professional standing together with aiding and promoting individuals/ organizations to advance engineering training, safety and methods of working.

Eligibility: Those who can show practical and personal qualities needed to promote engineering in relation to civil and municipal engineering. See the website for more details.

Level of Study: Graduate, Professional development, Research Type: Grant

Value: UK£1,000 upwards depending on submission

Study Establishment: Varies

Country of Study: Worldwide

Application Procedure: Applicants can download an application form from the website or request form from the Trust Secretary. In addition to this an online application can also be made.

Closing Date: Check with website

Funding: Private

Contributor: Institution of Works and Highways Management

No. of awards given last year: 14

No. of applicants last year: 58

Additional Information: Please see the website for further details www. bernardbutlertrust.org/grants.php. 